\title{
PAULO VARONI CAVALCANTI
}

Hibridização in situ em espermatozóides bovinos tratados com DNA exógeno: estudo experimental

São Paulo

2010 


\section{PAULO VARONI CAVALCANTI}

Hibridização in situ em espermatozóides bovinos tratados com DNA exógeno: estudo experimental

Dissertação apresentada ao Programa de PósGraduação em Reprodução Animal da Faculdade de Medicina Veterinária e Zootecnia da Universidade de São Paulo para obtenção do título de Mestre em Ciências

\section{Departamento:}

Reprodução Animal

Área de concentração:

Reprodução Animal

Orientador:

Profa. Dra. Mayra Elena Ortiz D'Avila Assumpção

São Paulo 
Autorizo a reprodução parcial ou total desta obra, para fins acadêmicos, desde que citada a fonte.

DADOS INTERNACIONAIS DE CATALOGAÇÃO-NA-PUBLICAÇÃO

(Biblioteca Virginie Buff D’Ápice da Faculdade de Medicina Veterinária e Zootecnia da Universidade de São Paulo)

Cavalcanti, Paulo Varoni

Hibridização in situ em espermatozóides bovinos tratados com DNA exógeno: estudo experimental / Paulo Varoni Cavalcanti. -- 2010.

$103 \mathrm{f}$. : il.

Dissertação (Mestrado) - Universidade de São Paulo. Faculdade de Medicina Veterinária e Zootecnia. Departamento de Reprodução Animal, São Paulo, 2010

Programa de Pós-Graduação: Reprodução Animal.

Área de concentração: Reprodução Animal.

Orientador: Profa. Dra. Mayra Elena Ortiz D’Avila Assumpção.

1. Transferência Gênica Mediada por Espermatozóides (TGME). 2. Animais transgênicos. 3. Eletroporação. 4. Fecundação in vitro. 5. Incubação. I. Título. 
ERRATA

CAVALCANTI, P. V. Hibridização in situ em espermatozóides bovinos tratados com DNA exógeno: estudo experimental. 2010. 103 f. Dissertação (Mestrado em Ciências) - Faculdade de Medicina Veterinária e Zootecnia, Universidade de São Paulo, São Paulo, 2010.
Folha
Parágrafo
Onde se lê
Ficha
$103 \mathrm{f}$.
Leia-se

catalográfica

1 . 103 f.


UNIVERSIDADE DE SÃO PAULO

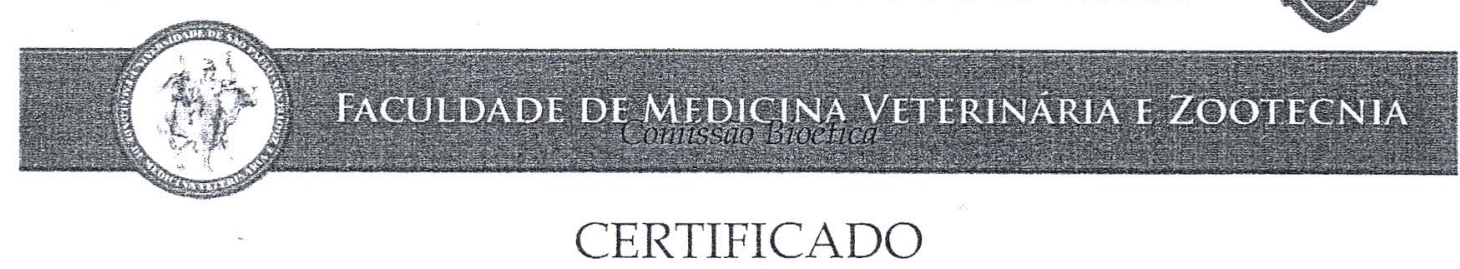

Certificamos que o Projeto intitulado "Hibridização in situ em espermatozóides bovinos tratados com DNA exógeno", protocolado sob o n 1458 /2008, utilizando ovários obtidos em abatedouro de animais destinados ao abate comercial, sob a responsabilidade da Profa. Dra. Mayra Elena Ortiz D’Avila Assumpção, está de acordo com os princípios éticos de experimentação animal da Comissão de Bioética da Faculdade de Medicina Veterinária e Zootecnia da Universidade de São Paulo e foi aprovado em reunião de 29 de outubro de 2008.

We certify that the Research "In situ hybridization in bovine sperm treated with exogenous DNA", protocol number 1458/2008, under the responsibility Profa. Dra. Mayra Elena Ortiz D'Avila Assumpção, agree with Ethical Principles in Animal Research adopted by Bioethic Commission of the School of Veterinary Medicine and Animal Science of University of São Paulo and was approved in the meeting of day $10 / 29 / 08$.

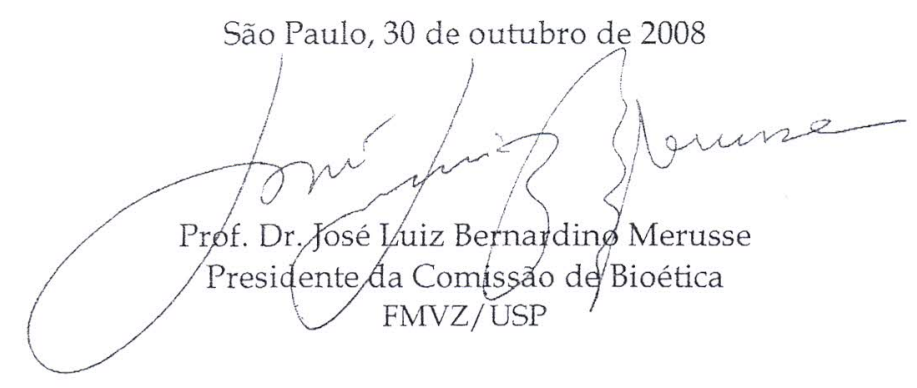


Nome: CAVALCANTI, Paulo Varoni

Titulo: Hibridização in situ em espermatozóides bovinos tratados com DNA exógeno: estudo experimental

Dissertação apresentada ao Programa de Pós- graduação em Reprodução Animal da Faculdade de Medicina Veterinária e Zootecnia da Universidade de São Paulo para obtenção do título de Mestre em Ciências

Data:

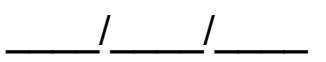

Banca Examinadora

Prof. Dr. Instituição:

Assinatura: Julgamento:

Prof. Dr. Instituição:

Assinatura: Julgamento:

Prof. Dr. Instituição:

Assinatura: Julgamento: 


\section{DEDICATÓRIA}

Dedico esta dissertação à Mayra Elena Ortiz D'Avila Assumpção, amiga, professora e orientadora. Pelos seus ensinamentos sobre a vida e a forma de encará-la. 


\section{AGRADECIMENTOS}

Agradecer é uma tarefa difícil, não por falta de humildade para dizer obrigado, simplesmente por ser impossível transformar em palavras sentimentos tão profundos de respeito e admiração.

\section{À família}

Toda a formação do caráter de um homem vem de sua família, por isso agradeço a meus pais Roberto e Maria por me direcionarem, trocando experiências de forma tão intensa e carinhosa.

Agradeço a meu irmão Pedro que por ser mais velho, sempre foi e é uma referência na qual me espelho.

Dedico todo meu reconhecimento à minha irmã Isadora, a qual tive a oportunidade de acompanhar todas as fases de sua formação, desde a concepção, é indescritível meu amor.

Poucas pessoas são abençoadas com mais que dois pais, por isso agradeço a meus padrastos Sônia e Anísio que tanto contribuem, cada um à sua maneira, com suas vivências tornando mais rica e feliz nossa família.

Não poderia deixar de agradecer meus avós Haydée, Plínio e Teresinha, que tanto me ensinam ética, integridade e boa conduta. Agradeço à minha avó Gabriela, que mesmo após sua partida, deixa marcas fortes de como ser uma pessoa batalhadora.

Em alguns momentos da vida são necessários impulsos para gerar mudanças e crescimento, obtive de meus tios Rita e Marcelo essa força necessária para me reencontrar, muito obrigado.

Não tenho palavras para agradecer meus primos Vinicius, Bruno e Marcela, por vezes os laços familiares são insuficientes para justificar a relação de intimidade e amizade que desenvolvemos.

Quando pessoas próximas crescem causam, espontaneamente, nosso progresso, deste modo, agradeço a meus primos Ulisses, Gustavo e Marta toda a troca e taxa acelerada de crescimento.

Agradeço meus tios Paulo e Hena pelo carinho, preocupação e admiração por minha profissão.

\section{Aos amigos}

Agradeço minha grande amiga Silvana Marchioro, que dividiu por muitos anos sua vida comigo; sua luz segue me iluminando.

Sou grato à amiga Renata Borelli que, como um anjo, entrou em nossa família.

Agradeço todos os ensinamentos compartilhados por Javan Jr., grande amigo e veterinário por formação prática. 
Agradeço ao amigo Giuliano, pela parceria e apoio em todos os churrascos do departamento.

\section{À Universidade Federal de Pelotas}

Agradeço à Universidade Federal de Pelotas, Instituição onde realizei minha graduação e ao Centro de Biotecnologia, local onde realizei minha iniciação científica.

Agradeço aos professores Dr. João Carlos Deschamps, Dr. Hedem Moreira e Dr. Tiago Collares pela motivação, liberdade de trabalho e orientação.

Agradeço aos colegas de trabalho do Laboratório de Biotecnologia da Reprodução Animal, Marta Amaral, Vinicius Campos, Evelise, Adeline, Alinca e Cristian.

\section{À Universidade de Osaka}

Agradeço ao professor Dr. Masaru Okabe e sua secretária Megume Okaua do Centro de Pesquisa em Informações Genômicas da Universidade de Osaka, pela doação do vetor pCX-EGFP.

Agradeço ao professor Dr. Junichi Miyazaki pela permissão de uso da seqüência pCAGGS.

\section{À família VRA - FMVZ - USP}

A definição da palavra família pode ser descrita por "núcleo parental de indivíduos com características comuns", no entanto, esta descrição literal deixa de contemplar os aspectos emocionais das relações familiares. Encontrei no Departamento de Reprodução Animal (FMVZ-USP) uma verdadeira família com todas as interações afetivas características dos laços familiares.

Agradeço à Mayra Elena Ortiz D'Avila Assumpção por inúmeras contribuições na minha formação, propiciando a conquista de um grande sonho. Seu carinho durante períodos difíceis foi fundamental, muito obrigado.

José Antônio Visintin muito obrigado pela co-orientação, sua forma de trabalho e conduta são exemplos que levarei comigo.

Agradeço aos amigos de laboratório Alesandra Nicacio, Aníbal Nascimento, Ana Rita Coutinho, Marcelo Goissis, Maria Angélica, Marcella Milazzotto, Mariana Groke, Flávia Barros, José Sérgio, Weber Feitosa, Fabíola Lopes, Mariana Giassetti, Camilla Mota, Silvia Crusco, Fernanda Sevciuc, Renata Simões, Julia Baldrighi, Adriano Siqueira, Everton Lopes, Pedro Risolia, Giana Pimentel, Márcia Monteiro, Robinson Worst, Rafaela Sanches, Jéssica Espada, Enrico Sala, Andrez Gonzalez, Samir Nicolau e Maíra Bianchi, por todo o convívio e troca de experiências. Cada um de vocês contribuiu com minha formação de forma única e especial, tenho todos como grandes amigos. 
Quero agradecer em especial minha aluna de iniciação científica Mariana Queiroz, que tanto me ensinou, muito mais do que eu à ela. Sua determinação e força de vontade à levarão a horizontes inimagináveis.

Não poderia deixar de agradecer aos professores do departamento de Reprodução Animal Camila Vannucchi, Renato Barnabé, Valquíria Barnabé, Pietro Baruselli, Marcelo Guimarães, Cláudio Oliveira, Annelise Traldi, Rubens Arruda, Ed Hoffmann, Eneiva Carla e Cláudia Fernandes, os quais apresentam grande competência profissional e amor a docência.

Agradeço aos colegas de pós-graduação Marcilio Nichi, Eduardo Gualtieri, Rodrigo Otávio, Mariana Rodrigues, Patrícia Cardoso, Paola Goes, Lilian Kirsch, Rodrigo Amaral, Marina Barros, Guilherme Silva, Fernanda Regazzi, Liege Garcia, Cristina Lucio, Gisele Veiga, Fabian Tarrago, José Rodrigo, Patrícia Miguez, André Furugen, Fabiane Zaffalon, Andres Meija, Guta Alonso, André Gotardo, Kedson Neves, Gabriel Crepaldi, Alessandra Teixeira, José Nélio, Lindsay Gimenes, Nelcio Carvalho, Manuel Sá, Roberta Ferreira, Henderson Ayres, Aline Kehrle, Janahi Ticianelli, Juliano Sangalli, Carolina Rocha, Bruna Oliveira, Saara Scolari e Rodrigo Alonso, foram muito bons os momentos que passamos juntos.

Quero agradecer aos funcionários Harumi, Thais, Alice, Anderson, Priscila, Miguel, Jocimar, Irailton, Luiz e Belau, vocês fazem a pós-graduação ser muito melhor e mais alegre.

Agradeço especialmente ao professor Dr. Marcilio Nichi, presidente da CCVRA, pelas análises e aulas de estatística.

Agradeço a amiga e professora Dra. Marcela Milazzotto pela ajuda na realização dos PCRs, me salvando das contaminações de primers.

Agradeço as amigas Dra. Renata Simões, Msc. Flavia Barros, Dra. Mariana Groke e Dra. Camilla Mota pela ajuda na realização da FIV, me ajudando passo a passo nas manipulações.

\section{Aos novos amigos}

O equilíbrio homeostático característico da vida, por vezes, é desviado à muito próximo das fronteiras da vida. Nestes momentos nos aproximamos de Deus e sentimos a força de sua presença. Abre-se a oportunidade de vislumbrar as virtudes humanas de pessoas que entram em nossas vidas de forma inesperada - Anjos.

Sou grato aos paramédicos Fábio e Paulo, pela competência com que executam seu trabalho e o respeito que tratam a fragilidade humana.

Agradeço também ao ortopedista Dr. Rubens (HU), pela destreza e atenção com a qual tratou de minha lesão.

Sou extremamente agradecido ao fisioterapeuta Dr. Gabriel (HU), que têm me ensinado a levantar e andar, mesmo que mancando um pouquinho, após um tombo na vida.

Que Deus continue iluminando suas vidas para que possam irradiá-la a quem precisa de vocês. 


\section{Ao abatedouro Angelelli}

Agradeço a toda equipe e funcionários do abatedouro Angelelli de Piracicaba, pela coleta de materiais, possibilitando que este trabalho fosse realizado.

Agradeço em especial o Sr. João, pela dedicação e disponibilização de seu tempo para a organização das coletas de ovários.

Agradeço a Patrícia que com boa vontade organizava a logística da coleta e entrega do material.

Agradeço o amigo Roberto por se deslocar, em sua moto, de São Paulo a Piracicaba para buscar o material, com a maior boa vontade.

Ao Laboratório de Ictiogenética - IB - USP

Agradeço a atenção prestada por Frederico Henning, durante o treinamento em hibridização in situ.

Quero agradecer à Msc. Felipe Claro, por disponibilizar seu tempo para o preparo das lâminas e leitura das hibridizações in situ. Muito obrigado Felipe!

Agradeço a profa. Dra. Lurdes Toledo por disponibilizar seu laboratório para a realização das hibridizações deste trabalho.

\section{A Central VR de Sêmen}

Agradeço a Central VR de Sêmen pela doação de sêmen, que foi crucial para execução deste trabalho, muito obrigado.

\section{A FAPESP}

Agradeço a Fundação de Amparo a Pesquisa do Estado de São Paulo, por disponibilizar os recursos necessários a este estudo. 


\section{EPÍGRAFE}

"No princípio era a simplicidade. Já é bastante dificil explicar até mesmo como um universo simples começou. (...) Não sabemos que matérias primas químicas eram abundantes na Terra antes do surgimento da vida, mas entre as possibilidades plausíveis estão água, dióxido de carbono, metano e amônia. (...) Mais recentemente, simulações em laboratório das condições químicas existentes na Terra antes do surgimento da vida têm produzido substâncias orgânicas chamadas purinas e pirimidinas. Estas substâncias são blocos de construção da molécula genética, o próprio DNA. (...) Processos análogos a esses devem ter dado origem ao "caldo primitivo" o qual, biólogos e químicos acreditam, constituiu os mares de cerca de três a quatro bilhões de anos atrás. As substâncias orgânicas concentraram-se localmente, talvez na espuma que secava nas praias ou em gotículas minúsculas suspensas. Sob a influência ulterior de energia, como luz ultravioleta proveniente do Sol, elas combinaram-se em moléculas maiores. (...) Num dado momento, uma molécula particularmente notável foi formada acidentalmente. (...) Ela não precisa necessariamente ter sido a molécula maior ou a mais complexa existente, mas possuía a propriedade extraordinária de ser capaz de criar cópias de si mesma."

Richard Dawkins 


\section{RESUMO}

CAVALCANTI, P. V. Hibridização in situ em espermatozóides bovinos tratados com DNA exógeno: estudo experimental. [in situ hybridization in bovine sperm treated with exogenous DNA: an experimental study]. 2010. $103 \mathrm{f}$. Dissertação (Mestrado em Ciências) - Faculdade de Medicina Veterinária e Zootecnia, Universidade de São Paulo, São Paulo, 2010.

Muitas das técnicas utilizadas para gerar animais transgênicos são caras e laboriosas. Neste contexto, a transferência gênica mediada por espermatozóides (TGME) pode ser uma alternativa para a produção em larga escala de animais transgênicos. Estudos de SMGT têm seu foco no número de cópias de DNA incorporada pelo espermatozóide. Por isso, há pouca informação disponível sobre como as moléculas de DNA se comportam durante o processo de fecundação e quais os efeitos dos protocolos de TGME sobre a célula espermática. Neste sentido, com o objetivo de avaliar a existência de sitio de integração preferencial das moléculas exógenas de DNA no genoma hospedeiro, utilizamos a hibridização in situ para acompanhar a veiculação do transgene durante 0 processo de fecundação. Foram avaliadas as membranas acrossomais, plasmática e potencial de membrana mitocondrial de espermatozóides submetidos a TGME. Para isso, o sêmen de três diferentes touros foram submetidos ao gradiente de Percoll $45-90 \%$. As células viáveis foram incubadas com o vetor recombinante pCX-EGFP $(0,250,500$ ou

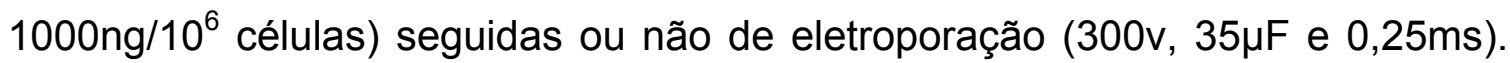
Os espermatozóides tratados foram utilizados para a produção in vitro de embriões. Os embriões foram cultivados por sete dias até o estágio de blastocisto. Espermatozóides e embriões produzidos in vitro foram submetidos ao ensaio de hibridização in situ, com metodologia descrita Whyte et al. (2000). $O$ potencial de membrana mitocondrial (PMM), integridade de membrana acrossomal (MA) e plasmática (MP) foram avaliados por citometria de fluxo (Guava Technologies, Hayward, CA, USA) utilizando as sondas fluorescentes JC1, FITC-PSA e PI (Molecular Probes), respectivamente. Os dados foram analisados pelo teste paramétrico ANOVA (teste LSD) usando o programa 
estatístico SAS for Windows, com nível de significância de 5\%. A hibridização in situ não foi possível em espermatozóides bovinos, pois não houve hibridação da sonda controle. Blastocistos oriundos de espermatozóides incubados com DNA exógeno apresentaram integração de forma difusa, embriões oriundos de espermatozóides eletroporados apresentaram integração pontual. As diferentes concentrações de DNA não exerceram efeitos deletérios nas MP ou PMM, a adição de 500ng de DNA causou aumento de lesão na MA $(p<0,05)$. A eletroporação não afeta a MP e MA, mais apresenta grande efeito no PMM causando redução da função mitocondrial. Este estudo conclui que maiores esforços são necessários para elucidar o comportamento das moléculas exógenas de DNA durante o processo de fecundação e quais são os efeitos da TGME sobre a célula espermática.

Palavras chave: Transferência Gênica Mediada por Espermatozóides (TGME). Animais Transgênicos. Eletroporação. Fecundação in vitro. Incubação. 


\section{ABSTRACT}

CAVALCANTI, P. V.: In situ hybridization in bovine sperm treated with exogenous DNA: an experimental study. [Hibridização in situ em espermatozóides bovinos tratados com DNA exógeno: estudo experimental]. 2010. 103 f. Dissertação (Mestrado em Ciências) - Faculdade de Medicina Veterinária e Zootecnia, Universidade de São Paulo, São Paulo, 2010.

Most techniques used to produce transgenic animals are laborious and expensive. In this manner, sperm mediated gene transfer (SMGT) may be a viable alternative for long-scale production of transgenic animals. Many SMGT studies have focused the DNA internalization and number of DNA copies incorporated by spermatozoa. However, limited data is available about how foreign DNA molecules behave during fertilization and the direct effects of the SMGT technique on sperm cells. Hence, in order to monitor the existence of preferential integration sites by the exogenous DNA at the host genome, in situ hybridization was used to track the transgene conveyance during in vitro fertilization. In addition, acrosome and plasmatic membrane integrity and mitochondrial membrane potential of sperm cells subjected to SMGT were assessed. Briefly, thawed semen from three different bulls was submitted to a 4590\% Percoll gradient. Viable cells were incubated with recombinant PCX-EGFP vector $\left(0,250,500\right.$ or $1000 \mathrm{ng} / 10^{6}$ sperm cells) or incubated and electroporated $(300 \mathrm{~V}, 35 \mu \mathrm{F}$ and $0.25 \mathrm{~ms})$. Treated sperm cells were then used for in vitro production of embryos. Embryos were in vitro cultured for 7 days until blastocyst stage. Treated spermatozoa and in vitro produced blastocysts were submitted to in situ hybridization assay, as described by Whyte et al. (2000). The mitochondrial membrane potential (MMP), acrosomal membrane (AM) and plasmatic membrane (PM) integrity were assessed by flow cytometry (Guava Technologies, Hayward, CA, USA) using JC1, FITC-PSA and PI probes (Molecular Probes), respectively. Data were analyzed by parametric ANOVA (LSD test) using SAS for Windows software, at a $5 \%$ level. The transgene was not observed at the bovine spermatozoa because the control probe could not be hybridized. In situ hybridization revealed that blastocysts produced from incubated sperm cells had a diffuse foreign DNA integration while blastocysts 
produced from electroporated sperm cells had a punctual DNA integration. No deleterious effects of exogenous DNA concentrations on PM or MMP were observed. However, the addition of 500ng of exogenous DNA caused sperm AM injury $(P<0.05)$. Electroporation did not affect $P M$ or $A M$ integrity, but it had a great effect on MMP, which may cause a reduction of mitochondrial function. This study suggest that more efforts are needed to elucidate the behavior of exogenous DNA during fertilization and the effects of SMGT in bovine sperm cells.

Key Words: Sperm Mediated Gene Transfer (SMGT). Transgenic Animals. Electroporation, In vitro fertilization, Incubation 


\section{LISTA DE FIGURAS}

Figura 1 Desenho esquemático do mecanismo de ligação, captação e interiorização de moléculas exógenas de DNA por espermatozóides. Após o contato do espermatozóide com as moléculas exógenas de DNA ocorre a ligação entre as DNA binding proteins (DBP) e o DNA. Moléculas de CD4 complexam a este conjugado primário carreando-o para o interior da célula. Quando este complexo alcança o núcleo, as moléculas de DNA exógeno são liberadas e as proteínas retornam para a superfície celular. Na presença de IF-1 este mecanismo fica inibido.

Figura 2 Linha do tempo das principais descobertas da Transferência Gênica Mediada por Espermatozóides

Figura 3 Espermatozóide de Macaco Rhesus durante o processo de fecundação in vitro. À esquerda, DNA plasmidial marcado com rodamina é removido, na superfície do oócito, durante a FIV (seta amarela). $O$ espermatozóide parcialmente penetrado demonstra a perda do DNA plasmidial em sua porção interiorizada (seta verde). À direita, imagem do mesmo plano focal. Fonte: Chan et al. (2000).

Figura 4 Modelo hipotético gráfico do delineamento experimental do experimento 1. Este experimento visa avaliar o efeito de diferentes concentrações de DNA e dos diferentes tratamentos (incubação e eletroporação) para a integração do DNA na viabilidade espermática utilizando técnicas de PCR em tempo real, de citometria de fluxo, de hibridização in situ e o perfil protéico por SDS-PAGE.

Figura 5 Descrição gráfica da relação temperatura pelo tempo da reação de qPCR. Passo 1 corresponde a desnaturação do DNA e ativação DNA polimerase. Passos de 2 a 4 correspondem ao ciclo da reação, o qual foi repetido por 40 vezes. Passos de 5 a 8 correspondem a curva de dissociação.

Figura 6 Desenho esquemático do gradiente Percoll ${ }^{\circledast}$. As setas indicam as fases onde foram retiradas amostras para a realização do perfil eletroforético das proteínas seminais.

Figura 7 Modelo gráfico do delineamento experimental do Experimento 2. Este experimento avalia o efeito dos protocolos de TGME sobre o potencial de produção e desenvolvimento in vitro de embriões. No processo de PIV foram avaliadas as taxas de clivagem, blastocisto e eclosão. Os embriões resultantes da PIV foram avaliados quanto a expressão do gene marcador da EGFP (microscopia de epifluorescência), presença do gene (PCR) e localização do inserto (FISH)

Figura 8 Valores médios e erro padrão da média do número de cópias do fragmento amplificado em tempo real, para cada $200 \mathrm{ng}$ de DNA total dos espermatozóides, nos distintos tratamentos. Inc $=$ espermatozóides apenas incubados com o vetor pCX-EGFP; 
Inc/DNAse = espermatozóides do grupo Inc após tratamento com DNAse I; Eletro = espermatozóides incubados com DNA exógeno e depois eletroporados; Eletro/DNAse = espermatozóides do grupo Eletro após tratamento com DNAse I.

Figura 9 Efeito da adição de DNAse I sobre o número de cópias amplificadas por qPCR para cada $200 \mathrm{ng}$ de DNA total extraídos de espermatozóides. DNAse - = espermatozóides incubados com 0 vetor recombinante pCX-EFP; DNAse $+=$ espermatozóides após tratamento com DNAse I.a,b: Letras diferentes indicam diferença significativa entre colunas $(p>0,05)$.

Figura 10 Efeito da adição de diferentes concentrações de DNA (250, 500 e 1000ng) sobre o número de cópias amplificadas em tempo real para cada $200 \mathrm{ng}$ de DNA total, extraídos de espermatozóides. a,b: Letras diferentes indicam diferença significativa entre colunas $(p>0,05)$.

Figura 11 Efeito dos distintos métodos de transfecção (incubação e eletroporação) sobre o número de cópias amplificadas em tempo real, para cada $200 \mathrm{ng}$ de DNA total extraídos de espermatozóides. a,b: Letras diferentes indicam diferença significativa entre colunas $(p>0,05)$.

Figura 12 Efeito da adição de diferentes concentrações de DNA sobre as variáveis espermatozóides íntegros (INT), com lesão de membrana plasmática (LMP), com lesão de membrana acrosomal (LMA) e com lesões em ambas as membranas (LMP/LMA). Letras minúsculas $(a, b)$ indicam diferença significativa entre as médias dentro da mesma variável $(p<0,05)$.

Figura 13 Efeito da aplicação de disitntos métodos de transfecção sobre as variáveis íntegros (INT), lesão de membrana plasmática (LMP), lesão na membrana acrosomal (LMA) e lesões em ambas as membranas (LMP/LMA), nos distintos métodos de transfecção (incubação ou eletroporação). Letras minúsculas $(a, b)$ indicam diferença significativa entre as médias dentro da mesma variável $(p<0,05)$.

Figura 14 Efeito das diferentes concentrações de DNA exógeno $(0,250$, $500,1000)$ sobre a susceptibilidade do DNA espermático à desnaturação ácida (fragmentação de DNA). Letras minúsculas $(a, b)$ indicam diferença significativa entre as médias, dentro da mesma variável $(p<0,05)$.

Figura 15 Efeito dos métodos de transfecção (incubação ou eletroporação) sobre a susceptibilidade do DNA espermático à desnaturação ácida (fragmentação de DNA). Letras minúsculas $(a, b)$ indicam diferença significativa entre as médias dentro da mesma variável $(p<0,05)$.

Figura 16 Fotografia da hibridização in situ controle das células espermáticas, com uso de sonda telomérica. Não foi observado sinal de fluorescência (Magnitude $200 \mathrm{x}$ ). 
Figura 17 Concentração protéica em $\mathrm{mg} / \mathrm{ml}$ das distintas fases do gradiente de Percoll. Fase 1, representa o conteúdo da fase superior. Fase 2, corresponde ao conteúdo da fase intermediária do gradiente. Fase 3, fase inferior do gradiente. Meio de lavagem, meio TALP onde $50 \mu \mathrm{l}$ do sedimento celular foi diluído (1:8) e centrifugado para remover partículas de Percoll residuais. Meio TALP apresenta $3,6 \mathrm{mg} / \mathrm{ml}$ de proteínas totais. A linha representa a tendência das amostras.

Figura 18 Perfil eletroforético em SDS-PAGE das proteínas do gradiente de Percoll. 1, proteína referência de $55 \mathrm{KDa}$. 2, meio de congelação onde os espermatozóides foram congelados. 3, proteínas da Fase 1. 4, proteínas da Fase 2. 5, proteínas da Fase 3. 6, proteínas do meio no qual o sedimento celular foi diluído para a remoção das partículas residuais de Percoll.

Figura 19 Fotografias dos embriões produzidos in vitro após protocolo de TGME. Em "A" embriões do grupo controle, em "B" os mesmos embriões sobre a excitação da luz ultravioleta e filtro de 480 $507 \mathrm{~nm}$ (magnitude de $100 \mathrm{x}$ ). Em "C e D" blastocisto expandido do grupo incubação. Em "E e F" blastocisto inicial do grupo eletroporação (magnitude de $200 \mathrm{x}$ ).

Figura 20 Análise eletroforética em gel de agarose a $3 \%$ do produto de 67 $\mathrm{pb}$ amplificado da região codificadora da EGFP de embriões produzidos in vitro. M, Marcador de massa molecular de $50 \mathrm{pb}$. $\varnothing$, Controle negativo da reação. $\oplus$, Controle positivo da reação.

Figura 21 Micrografias das hibridizações in situ em embriões. Em A1-4 embriões controle com marcações de sonda telomérica (verde). Em B1-4 embriões do grupo eletroporado apresentando sinal de marcação para o vetor pCX-EGFP (tons de vermelho). Em C1-4 embriões do grupo incubado e sinais de marcação da sonda pCX-EGFP (tons de vermelho)

Figura 23 Diagrama do vetor pCX-EGFP. Seta verde superior corresponde à região promotora de citomegalovírus (CMV-IE); seta azul demarca a sequência promotora do gene da beta-actina de galinha (beta-actin); linha azul corresponde ao primeiro íntron do gene de beta-actina de galinha (íntron 1); seta laranja inferior demarca a região codificadora do gene da GFP (EGFP cDNA).

Figura 24 Eletroforese do vetor pCX-EGFP, 0,1 ug/ul em gel de agarose a $0,8 \% ; 1 \mathrm{~kb}$ - marcador de 1 quilo base; Mass - Marcador de massa molecular (Invitrogen).

Figura 25 Gel de agarose $(0,8 \%)$ dos produtos de PCR das colônias pCXEGFP. (+) controle positivo; (-) controle negativo; $(1,2,3,4)$ Colônias; $(\mathrm{C}+)$ colônia mais vetor.

Figura 26 Análise Eletroforética em gel de agarose $(0,8 \%)$ da extração de DNA plasmidial; (1) $14,7 \mathrm{ng} / \mu \mathrm{l}$; (2) $22,4 \mathrm{ng} / \mu \mathrm{l}$;(3) $160,9 \mathrm{ng} / \mu \mathrm{l} \mathrm{e}$ (4) $138,0 \mathrm{ng} / \mu \mathrm{l}$. 
Figura 27 Análise da eletroforese em gel de agarose (0,8\%) dos fragmentos gerados após a digestão enzimática; A) Vetor Colônia 3 não digerido; B) Vetor colônia 3 digerido com as enzimas Sall e EcoRl; C ) Vetor colônia 3 digerido com as enzimas Hindlll e BamHI; D) Vetor Colônia 4 não digerido; E ) Vetor colônia 4 digerido com as enzimas Sall e EcoRl; F ) Vetor colônia 4 digerido com as enzimas Hindlll e BamHl; $1 \mathrm{~Kb}=$ marcador.

Figura 28 Análise eletroforética em gel de agarose $(0,8 \%)$ dos estados conformacionais do vetor plasmidial pcx-EGFP. A) vetor linear após corte com a enzima Stul; B) Conformação circular - sem digestão enzimática. M) Marcador de $1 \mathrm{~Kb}$.

Figura 29 Descrição gráfica da relação temperatura pelo tempo da reação de qPCR. Passo 1 corresponde à desnaturação do DNA e ativação da DNA polimerase. Passos de 2 a 4 correspondem ao ciclo da reação que foi repetido por 40 vezes. Passos de 5 a 8 correspondem à curva de dissociação.

Figura 30 Relação entre ciclo de amplificação e número de cópias do vetor. Pontos vermelhos marcam as reações com concentrações de vetor conhecidas, cruzes negras marcam os valores da amostras mensuradas.

Figura 31 Gráfico da fluorescência pelo ciclo da reação de qPCR. As linhas de diferentes cores correspondem a amostras diferentes. Traço horizontal vermelho corresponde a linha de análise, pelo qual o valor de cada amostra é mensurado.

Figura 32 Curva de dissociação, pico à $80^{\circ} \mathrm{C}$ corresponde ao ponto de dissociação do fragmento amplificado. Traço verde corresponde ao controle negativo da reação.

Figura 33 Dotplot de fluorescência verde por vermelho resultante da avaliação das células espermáticas com as sondas FITC-PSA juntamente com PI. Em azul estão as células íntegras sem qualquer tipo de lesão, em verde as células que sofreram apenas lesão na membrana acrossomal, em vermelho células com lesão somente na membrana plasmática e em laranja a população celular que sofreu lesões em ambas as membranas (plasmática e acrossomal).

Figura 34 Dotplot da fluorescência verde pela amarela resultante da avaliação das células espermáticas com a sonda JC-1. Em vermelho a população de espermatozóides com alto potencial de membrana mitocondrial, em laranja as células com potencial de membrana mitocondrial intermediário e em verde células com baixo potencial de membrana mitocondrial.

Figura 35 Exemplos de gráficos gerados pelo teste de SCSA. Em A, Dotplot da fluorescência verde pela amarela resultante da avaliação das células espermáticas no Ensaio de Estrutura de Cromatina. Em vermelho a dispersão da população de 
espermatozóides. Em B, histograma correspondente de $\alpha T$, entre barras está o valor de COMP $\alpha \mathrm{T}$.

Figura 36 Eletroforese em gel de agarose a $0,8 \%$ do produto da reação de Nick translation após 4 horas de incubação a $15^{\circ} \mathrm{C}$. À esquerda, marcador de massa molecular de $1 \mathrm{~kb}$ (invitrogen). À direita, os fragmentos do vetor entre a faixa de $3 \mathrm{~kb}$ a $100 \mathrm{pb}$.

Figura 37 Eletroforese em gel de agarose a $0,8 \%$ do produto da reação de Nick translation após 6 horas de incubação a $15^{\circ} \mathrm{C}$. À esquerda, marcador de massa molecular de $1 \mathrm{~kb}$ (invitrogen). À direita, os fragmentos do vetor entre a faixa de $100-500 \mathrm{pb}$. 


\section{LISTA DE TABELAS}

Tabela 1 Efeito da concentração de DNA (0, 250, 500, $1000 \mathrm{ng})$, do método de transfecção (incubação, eletroporação), da adição ou não de DNAse e respectivas interações sobre $0 n^{\circ}$ de cópias amplificadas de $200 \mathrm{ng}$ de DNA total, extraído de espermatozóides.

Tabela 2 Efeito da concentração de DNA (0, 250, 500, $1000 \mathrm{ng})$, do método de transfecção (incubação, eletroporação) e da interação DNA x método de transfecção sobre a porcentagem de células íntegras (INT); com lesão de membrana plasmática (LMP); com lesão de membrana acrossomal (LMA); com lesão em ambas membranas (LMP/LMA).

Tabela 3 Efeito da concentração de DNA (0, 250, 500, $1000 \mathrm{ng})$, do método de transfecção (incubação, eletroporação) e da interação DNA x método de transfecção sobre a porcentagem de espermatozóides com alto potencial de membrana mitocondrial (APMM) e baixo potencial de membrana mitocondrial (BPMM).

Tabela 4 Porcentagem de células com alto potencial de membrana mitocondrial (APMM) nos diferentes tratamentos.

Tabela 5 Percentagem de células com baixo potencial de membrana mitocondrial (BPMM) nos diferentes tratamentos.

Tabela 6 Efeito da concentração de DNA (0, 250, 500, $1000 \mathrm{ng})$, do método de transfecção (incubação, eletroporação) e da interação DNA x método de transfecção sobre a susceptibilidade do DNA espermático à desnaturação ácida (fragmentação de DNA).

Tabela 7 Efeito dos métodos de transfecção (controle, incubação, eletroporação) nos índices de Clivagem, Blastocisto e Eclosão dos embriões bovinos produzidos in vitro com uso dos espermatozóides tratados com 1000 ng de DNA exógeno.

Tabela 8 Porcentagem de embriões positivos para fluorescência compatível com GFP e porcentagem de embriões positivos para a PCR, por método de transfecção (incubação e eletroporação). 


\section{LISTA DE ABREVIATURAS E SIGLAS}

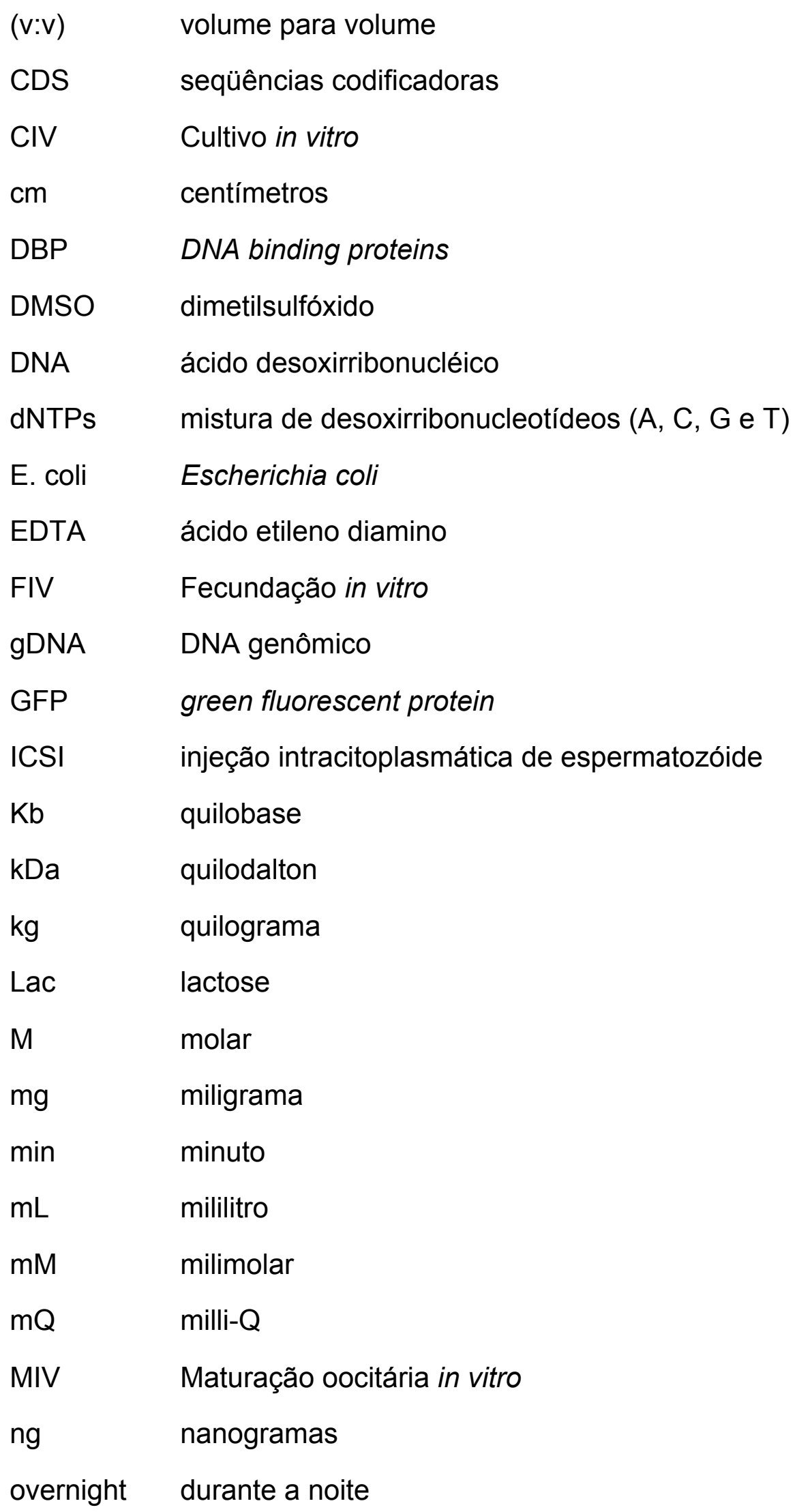




$\begin{array}{ll}\text { pb } & \text { pares de base } \\ \text { PBS } & \text { tampão de fosfato salino } \\ \text { PCR } & \text { polymerase chain reaction (Reação em Cadeia da Polimerase) } \\ \text { qsp } & \text { quantidade suficiente para } \\ \text { SDS-PAGE } & \text { sodium dodecyl sulfate polycrylamide gel electrophoresis } \\ \text { Taq } & \text { thermophilus aquaticus } \\ \text { TBE } & \text { tris-Boro-EDTA } \\ \text { TE } & \text { tris-EDTA } \\ \text { TGME } & \text { transferência gênica mediada por espermatozóides } \\ \text { TGMT } & \text { transferência gênica mediada por testículo } \\ U & \text { unidades } \\ \text { UV } & \text { ultravioleta } \\ V & \text { volts } \\ \mu g & \text { micrograma } \\ \mu \mathrm{l} & \text { microlitro } \\ \mu m & \text { micrometro } \\ & \end{array}$




\section{LISTA DE SÍMBOLOS}

$\begin{array}{ll}{ }^{\circ} \mathrm{C} & \text { graus Celsius } \\ \% & \text { porcentagem } \\ < & \text { menor } \\ > & \text { maior } \\ = & \text { igual } \\ + & \text { mais }\end{array}$




\section{SUMÁRIO}

1 INTRODUÇÃO

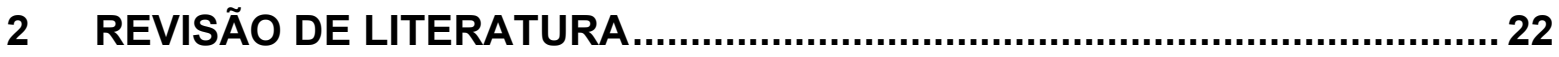

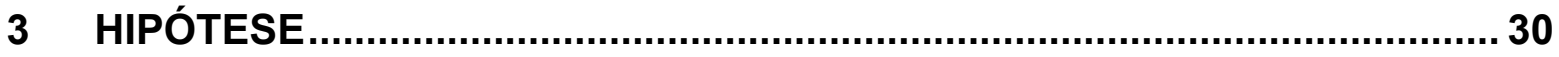

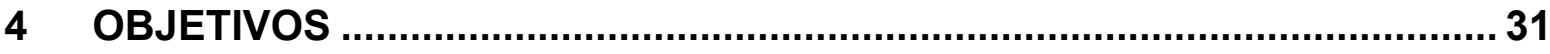

$5 \quad$ MATERIAIS E MÉTODOS.........................................................................32

5.1 Experimento 1 - Estudo dos efeitos da TGME em espermatozóides bovinos ...32

5.1.1 Quantificação da captação espermática de moléculas DNA .....................................34

5.1.2 Efeito de protocolos de TGME em organelas espermáticas....................................36

5.1.3 Análise topográfica do inserto no genoma espermático .........................................39

5.1.4 Análise do perfil eletroforético das proteínas espermáticas ..................................40

5.2 Experimento 2 - Produção de embriões in vitro com uso de espermatozóides tratados com DNA exógeno.................................................................................41

5.2.1 Potencial de produção e desenvolvimento in vitro de embriões ...............................42

5.2.2 Avaliação da expressão do gene marcador em embriões produzidos in vitro............44

5.2.3 Análise da presença do gene marcador em embriões produzidos in vitro .................44

5.2.4 Análise topográfica do inserto em embriões produzidos in vitro..............................44

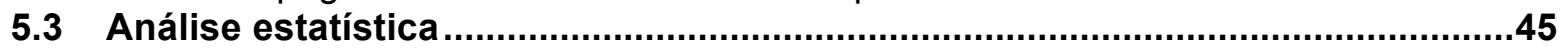

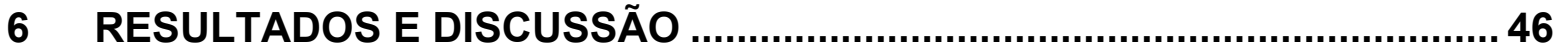

6.1 Experimento 1 - Estudo dos efeitos da TGME em espermatozóides bovinos ...46

6.1.1 Quantificação da captação espermática de moléculas DNA …................................46

6.1.2 Efeito de protocolos de TGME em organelas espermáticas ....................................51

6.1.3 Análise topográfica do inserto no genoma espermático .....................................58

6.1.4 Análise do perfil eletroforético das proteínas espermáticas ....................................60

6.2 Experimento 2 - Estudo do potencial de produção e desenvolvimento de embriões in vitro com uso de espermatozóides tratados com DNA exógeno ...61

6.2.1 Potencial de produção e desenvolvimento in vitro de embriões ................................62

6.2.2 Avaliação da expressão do gene marcador em embriões produzidos in vitro............63

6.2.3 Análise da presença do gene marcador em embriões produzidos in vitro ..................65

6.2.4 Análise topográfica do inserto em embriões produzidos in vitro...............................67

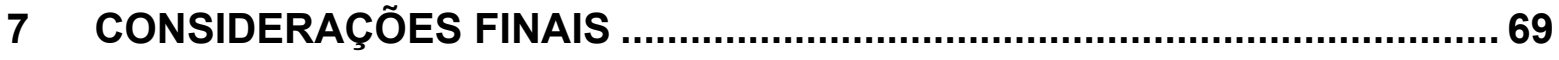

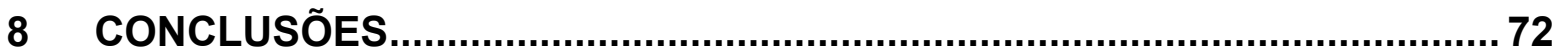

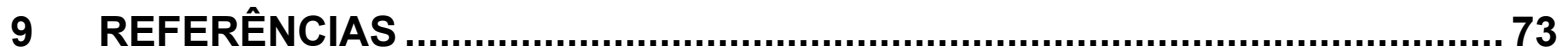

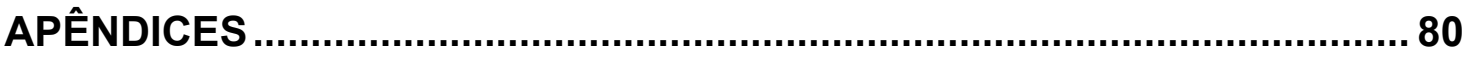

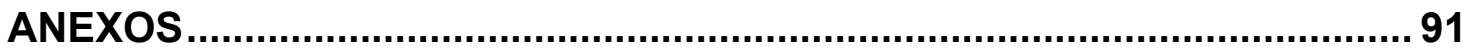


Trabalhando com seqüências de DNA viral e espermatozóides de coelho, Brackett et al. (1971) demonstraram, pela primeira vez, que moléculas exógenas de DNA poderiam ser espontaneamente interiorizadas em espermatozóides. Esta característica fisiológica dos espermatozóides permitiu o surgimento de uma nova biotecnologia baseada na função primária do espermatozóide: a de conduzir DNA para dentro do oócito, no entanto, além do DNA endógeno carreia também moléculas de DNA exógenas, gerando animais geneticamente modificados.

Esta biotecnologia recebeu o nome de transferência gênica mediada por espermatozóides (TGME). Ao longo dos anos sua aplicação vem sendo demonstrada em grande variedade de espécies: bovinos (GAGNE et al.,1991; SHEMESH et al., 2000; HOELKER et al., 2007) hamsters (FERNANDEZ et al., 1999; KUZNETSOV et al., 1999); camundongos (LAVITRANO et al.1997b; HUGUET; ESPONDA, 2000); suínos (LAVITRANO et al., 1997; CAPPELLO et al., 2000; CHANG et al., 2002; LAVITRANO et al., 2003); coelhos (KUZNETSOV et al., 2000; KUZNETSOV; KUZNETSOVA, 2000; ANDREEVA et al., 2003; SHEN et al., 2006) e peixes (KHOO et al., 2000; SIN et al., 2000, Collares et al., 2010).

No entanto, a eficiência e a repetibilidade da TGME é controversa, necessitando de maiores esforços para compreender os mecanismos na incorporação e na expressão do transgene (MAIONE et al., 1998; CELEBI et al., 2003).

Diversos pesquisadores buscam desenvolver novos procedimentos utilizando tratamentos físicos e químicos para incrementar a transferência gênica mediada por espermatozóides (KUZNETSOV et al., 1999; WALL, 2002; CELEBI et al., 2003). Espermatozóides maduros já foram submetidos a diferentes tratamentos, tais como: eletroporação (GAGNE et al., 1991; TSAl et al., 1997; KUZNETSOV et al., 1999; WALL, 2002; CELEBI et al., 2003); complexo lipossomo/DNA (TSAl et al., 1997; VALENZUELA et al., 2002); agentes retrovirais (FARRE et al., 1999; NAGANO et al., 2001; KOO et al., 2004); substâncias crioprotetoras (SHEN et al., 2006); anticorpos (LAVITRANO et al., 1997; WALL, 
2002) ou incubação dos espermatozóides com DNA exógeno seguido de injeção intracitoplasmática (ICSI) (KATO et al., 2004; HIRABAYASHI et al., 2005).

Muitos dos mecanismos envolvidos na TGME ainda não são bem conhecidos, restando dúvidas quanto à forma de veiculação das moléculas exógenas de DNA no processo de fecundação.

A interação DNA exógeno/espermatozóide e subseqüente interiorização ocorre preferencialmente na região sub-acrossomal dos espermatozóides, sendo mediada por glicoproteínas de superfície - CD4 (ZANI et al., 1995; LAVITRANO et al., 1997). A localização do DNA exógeno no núcleo do espermatozóide foi comprovada por microscopia eletrônica (FRANCOLINI et al., 1993), microscopia confocal (BACHILLER et al., 1991) e análises bioquímicas (ATKISON et al.,1991). No entanto, grande parte dos animais gerados por TGME não apresenta expressão ubíqua, sugerindo integração epissomal do transgene (SIN et al., 2000; YONEZAWA et al., 2001; PITTOGGI et al., 2006). Chan et al. (2000) demonstraram in vitro, que durante o processo de fecundação, as moléculas de DNA exógeno aderidas ao espermatozóide são removidas antes que este penetre no oócito. Esta remoção não ocorre quando os espermatozóides tratados com DNA exógeno são microinjetados (ICSI) em oócitos.

Compreender a interação do transgênese com o genoma do espermatozóide é crucial para elucidar os mecanismos da TGME no processo de fecundação. Huang et al. (2007) utilizando Hibridização in situ (FISH) demonstraram, em embriões microinjetados, que múltiplas cópias do transgene são integradas a poucos sítios do genoma hospedeiro. No entanto, estudos deste porte não foram realizados em espermatozóides geneticamente modificados ou em embriões gerados por TGME.

Este trabalho propõe utilizar a hibridização in situ para acompanhar a veiculação do transgene durante o processo de fecundação in vitro, observando se há algum sítio preferencial de integração do DNA exógeno no genoma do espermatozóide hospedeiro ou embrião. 
Tradicionalmente, espermatozóides são considerados células metabolicamente diferenciadas por não apresentarem processos bioquímicos fundamentais ou funções moleculares, como a replicação do DNA, a expressão gênica e a síntese protéica. Além desta particularidade metabólica, estas células possuem uma particularidade morfológica, caracterizada por um compartimento citoplasmático extremamente reduzido e um núcleo grande, o qual contém o DNA genômico, altamente compactado. Este complexo compõe a cabeça do espermatozóide, ao qual está conectado um longo flagelo. Estas características sugerem que o único papel desta célula seja o de carrear o genoma paterno para dentro do oócito, durante o processo de fecundação (SCIAMANNA et al., 2000).

Em 1971, Bracket et al. demonstraram que moléculas exógenas de DNA poderiam ser espontaneamente internalizadas em espermatozóides. Esta particularidade permitiu, na década de 80 , o surgimento de uma nova biotecnologia que utiliza a função primária do espermatozóide em conduzir DNA para dentro do oócito durante a fecundação. Entretanto, além do DNA endógeno este carrearia também moléculas exógenas de DNA, gerando animais geneticamente modificados. Esta nova tecnologia recebeu o nome de Transferência Gênica Mediada por Espermatozóides (TGME).

Embora fisiológico, os eventos de captação de DNA exógeno pelo espermatozóide não são aleatórios e sim mediados por proteínas espermáticas específicas presentes na membrana plasmática. Três grupos protéicos, denominados "DNA binding proteins" (DBP) foram identificados neste processo. $O$ primeiro apresenta peso molecular de aproximadamente $20 \mathrm{kDa}$, peso compatível com as protaminas espermáticas. O segundo grupo apresenta peso molecular entre 30-35 kDa, identificadas como proteínas de membrana, presente em espermatozóides de uma grande variedade de espécies, sendo estas as mais estudadas na TGME. O terceiro grupo, proteínas com $50 \mathrm{kDa}$, perdem a habilidade de interagir com o DNA durante as técnicas de eletroforese utilizadas na separação 
dos extratos protéicos. A interação DNA exógeno/espermatozóide e subseqüente interiorização ocorre preferencialmente na região sub-acrossomal dos espermatozóides, local prioritário de concentração das proteína de 30-35 KDa (ZANI et al., 1995; LAVITRANO et al., 1997b).

Após a captação das moléculas exógenas de DNA pelas DBP, os complexos DBP/DNA são interiorizados e conduzidos até o núcleo espermático. A primeira evidência da interiorização destas moléculas foi demonstrado por Francolini et al. (1993). O mecanismo utilizado pelas células espermáticas para internalizar estes complexos (DBP/DNA) tem o envolvimento de moléculas do sistema de histocompatibilidade maior de classe II (MHC II) e de glicoproteínas de superfície - CD4 (cluster of differentiation 4) (LAVITRANO et al., 1997). A Figura 1 exemplifica este processo de captação e internalização do DNA exógeno.

Camundongos knockout para o receptor $\mathrm{MHC}$ de classe II têm reduzida habilidade em captar DNA exógeno, quando comparado às linhagens selvagens. Inversamente, espermatozóides knockout para CD4 apresentam capacidade plena em captar moléculas exógenas de DNA, no entanto perdem a habilidade de interiorizar os complexos DBP/DNA (LAVITRANO et al., 1997).

Assim, embora não esteja presente em células espermáticas maduras, a expressão do MHC de classe II parece ser necessária durante a espermatogênese para produzir células espermáticas capazes de captar DNA exógeno. Moléculas de CD4 presentes na membrana plasmática dos espermatozóides são responsáveis pelo processo de interiorização nuclear do DNA aderido à membrana espermática (LAVITRANO et al., 1997b). Apesar de ser um bom veículo, os espermatozóides possuem muitas barreiras para a captação de DNA exógeno. Estas barreiras dependem da composição química das membranas dos espermatozóides, da composição do plasma seminal e de receptores espermáticos de superfície de cada espécie (CANOVAS et al., 2010).

O fato dos espermatozóides possuírem a capacidade de captar DNA exógeno, acarreta um risco para a manutenção da identidade genômica do indivíduo ou da espécie. Células espermáticas entram em contato com moléculas de DNA provenientes de resíduos celulares desde a ejaculação até o encontro com o gameta feminino. No entanto, a captação destas seqüências livres de DNA não 
ocorre naturalmente. Com base neste fenômeno, Zani et al. (1995) buscaram compreender qual seria o mecanismo que impede a entrada desenfreada de DNA exógeno nas células espermáticas. Verificaram que o plasma seminal possui uma proteína que tem a habilidade de inibir a interação DNA/espermatozóide. Este fator recebeu o nome de fator inibitório 1 (IF-1), caracterizado como uma glicoproteína de peso molecular de $37 \mathrm{KDa}$ que interage com proteínas espermáticas de membrana, impossibilitando a ligação do DNA exógeno. Para a remoção do IF-1 na TGME é necessário a remoção do plasma seminal. Estudos com espermatozóides de suínos evidenciam um efeito negativo na motilidade total e progressiva quando o plasma seminal é removido, sendo este efeito minimizado com a re-adição do plasma seminal. Os autores justificam este fenômeno pela presença de proteínas de manutenção da motilidade no plasma seminal de suínos (KANG et al., 2008).

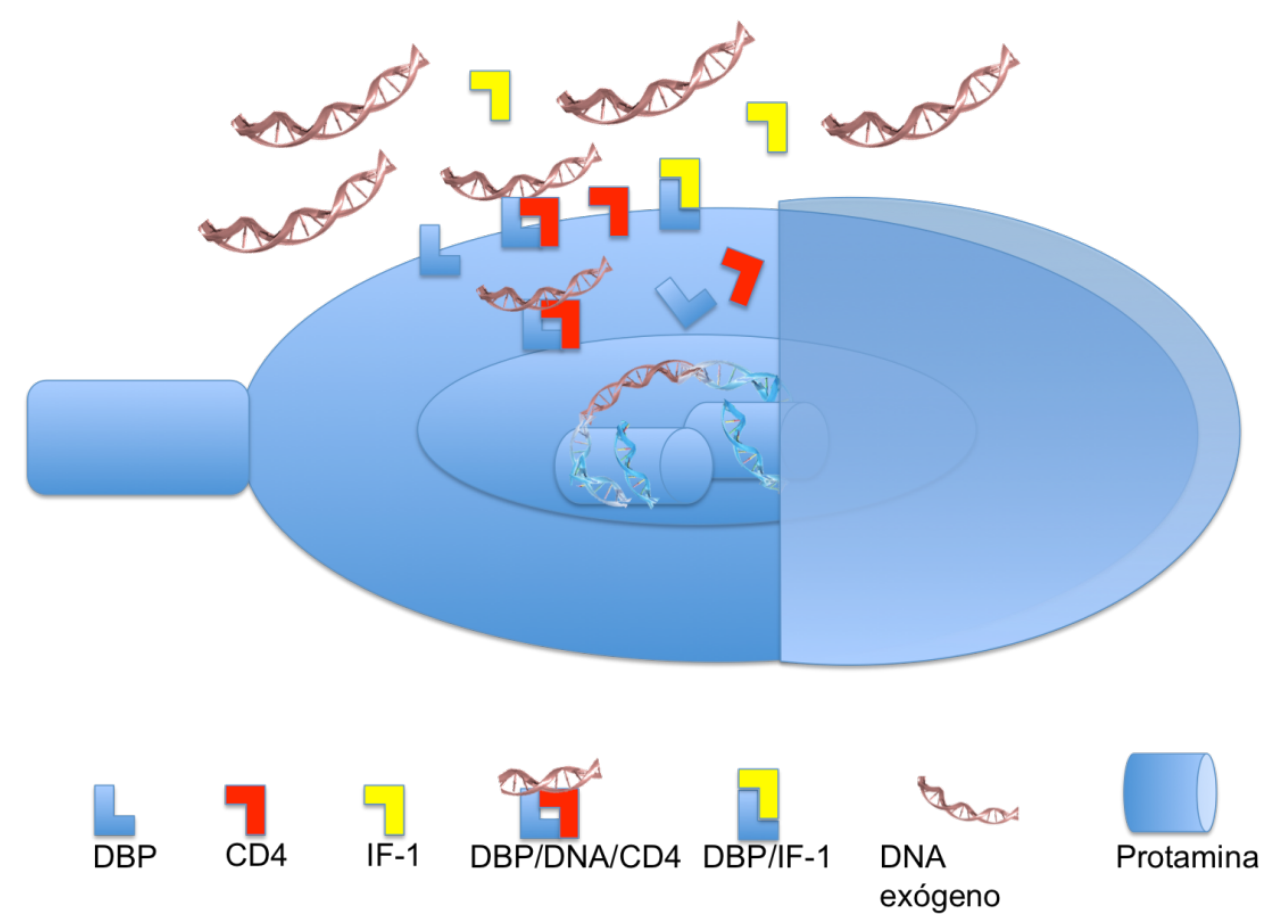

Figura 1 Desenho esquemático do mecanismo de ligação, captação e interiorização de moléculas exógenas de DNA por espermatozóides. Após o contato do espermatozóide com as moléculas exógenas de DNA ocorre a ligação entre as DNA binding proteins (DBP) e o DNA. Moléculas de CD4 complexam a este conjugado primário carreando-o para o interior da célula. Quando este complexo alcança o núcleo, as moléculas de DNA exógeno são liberadas e as proteínas retornam para a superfície celular. Na presença de IF-1 este mecanismo fica inibido.

Evidências demonstram que a integração das seqüências exógenas de DNA ocorre de forma dirigida em sítios específicos no genoma (SPADAFORA, 1998). 
Bibliotecas de DNA, construídas a partir de espermatozóides murinos após a TGME, revelaram que seqüências de DNA similares são encontradas nas extremidades das moléculas exógenas de DNA inseridas no genoma (ZORAQI; SPADAFORA, 1997).

Surpreendentemente, este sítio de integração apresentou alta homologia à seqüência consensu da enzima topoisomerase II, sugerindo possível envolvimento desta, no processo de recombinação (MAGNANO et al., 1998). A mais provável explicação para este evento específico de integração, em um ou poucos sítios, talvez esteja relacionado à estrutura altamente compactada da cromatina espermática. Presume-se que estes sítios, sejam aqueles, nos quais a compactação do DNA espermático não é tão intensa, provavelmente regiões de dobra do DNA entre as protaminas (SPADAFORA, 1998).

A célula espermática possui todos os recursos necessários para introduzir um gene de interesse no oócito. Apresenta fatores fundamentais para desencadear a ativação oocitária e os RNA mensageiros essenciais para desencadearem as primeiras divisões embrionárias (DADOUNE et al., 2009). Deste modo, o espermatozóide parece ser o veículo ideal para carrear fragmentos exógenos de DNA de interesse na tentativa de produzir um indivíduo transgênico.

Por isso, diversos pesquisadores buscam desenvolver novos procedimentos utilizando tratamentos físicos e químicos para incrementar a transferência gênica mediada por espermatozóides.

A aplicação de pulsos elétricos com alta voltagem (eletroporação) em espermatozóides previamente tratados com DNA, aumenta significativamente as taxas de incorporação do DNA exógeno (GAGNE et al., 1991; TSAl et al., 1997; KUZNETSOV et al., 1999; WALL, 2002; CELEBI et al., 2003). O número de eventos de recombinação em espermatozóides bovinos incubados com DNA é de $3,5 \%$ e aumenta para $46,5 \%$ quando utilizada a eletroporação (RIETH et al., 2000).

Encapsular moléculas de DNA em micelas de lipídios catiônicos formando complexos lipossomo/DNA tem demonstrado bastante eficiência na transfecção de espermatozóide (NORTHROP et al., 1987; TSAl et al., 1997). Espermatozóides bovinos incubados com DNA captam em média de uma a três moléculas de DNA 
por espermatozóide, já com o uso de lipossomos este número passa para 80 a 160 cópias por espermatozóide (ANZAR et al., 2006; HOELKER et al., 2007).

Diferenças de pressão osmótica também podem ser utilizadas para aumentar a eficiência da TGME. Shen et al. (2006) obtiveram um aumento significativo no número de animais transgênicos (camundongos e coelhos) nascidos com o uso do DNA diluído em dimetilsulfóxido (DMSO). Deste modo, a pressão osmótica exercida pela adição de DMSO resulta em trocas líquidas, que propiciam a interiorização de moléculas de DNA exógeno.

No entanto, os melhores resultados e que apresentam maior repetibilidade da técnica tem sido alcançada com o uso da injeção intracitoplasmática de espermatozóides (ICSI) após a incubação com DNA (KATO et al., 2004; HIRABAYASHI et al., 2005).

Uma das variações da técnica de TGME conhecida como "Transgênese ativa" utiliza enzimas para facilitar a incorporação do transgene no genoma hospedeiro. Kaneko et al. (2005) relatam o uso de recombinases ( $\operatorname{Rec} A$ ) ou transposases. A proteína transposase hiperativa Tn5 parece ser eficiente na integração de um transgene no genoma espermático para uso em TGME (SUGANUMA et al., 2005). Este método aumentou de forma significante a eficiência de produção de camundongos transgênicos. Shinohara et al. (2007) utilizando Tn5 e ICSI relataram resultados de $75 \%$ de camundongos transgênicos nascidos e expressando o transgene EGFP .

Objetivando entender os mecanismos moleculares envolvendo o processo Giordano et al. (2000), descobriram uma atividade endógena de transcrição reversa em espermatozóides murinos, o que permitiu o uso de moléculas de RNA para transfectar espermatozóides. A transcrição reversa de moléculas exógenas de RNA gera cópias de cDNA no citoplasma espermático, sendo estas transmitidas ao futuro embrião durante a fecundação. Sequências reversamente transcritas comportam-se como genes funcionais, com propagação epissomal, apresentando correta expressão nos tecidos de animais F0 e F1 (PITTOGGI et al., 2006).

Outra maneira de aumentar a eficiência da técnica é facilitar a condução do transgene à célula espermática utilizando proteínas veiculadoras. O principal 
representante deste grupo é o anticorpo monoclonal mAb C. O mAb C é uma proteína básica que se liga ao DNA por meio de interações iônicas permitindo que moléculas exógenas de DNA sejam conduzidas especificamente ao espermatozóide. Após a fecundação do oócito, o DNA é carreado para ser integrado no genoma do novo indivíduo. A transferência do gene da linhagem parental para à geração $\mathrm{F} 1$ apresentou alta taxa de eficiência: $37,5 \%$ para suínos e $33 \%$ para ratos. Além disso, a expressão do transgene foi demonstrada em $61 \%$ (35/57) dos animais na geração F0 (CHANG et al., 2002).

A Figura 2 resume as principais descobertas sobre a tecnologia de transferência gênica mediada por espermatozóides.

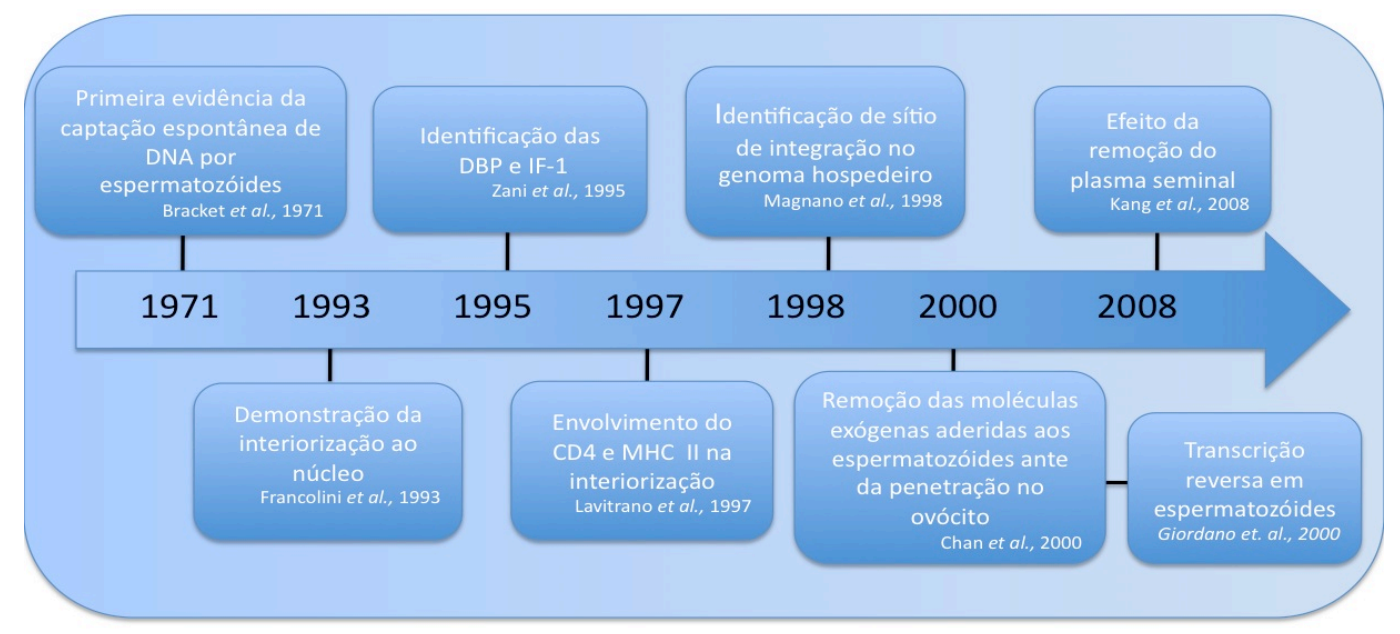

Figura 2 Linha do tempo das principais descobertas da Transferência Gênica Mediada por Espermatozóides

Ao longo dos anos, a TGME vem sendo aplicada em diversas espécies: bovinos (GAGNE et al.,1991; SHEMESH et al., 2000; HOELKER et al., 2007); hamsters (FERNANDEZ et al., 1999; KUZNETSOV et al., 1999); camundongos (LAVITRANO et al.1997b; HUGUET; ESPONDA, 2000;); suínos (CAPPELLO et al., 2000; CHANG et al., 2002; LAVITRANO et al., 2003); coelhos (KUZNETSOV et al., 2000; SHEN et al., 2006; VASICEK et al., 2007) e peixes (PATIL, KHOO et al., 1996; COLLARES et al., 2010).

Uma grande variedade de vetores recombinantes é descrita em protocolos de TGME, a escolha fica a critério do gene e do tecido a ser expresso. Moléculas exógenas de origem viral ou retro-transposons afetam diferentemente o 
desenvolvimento embrionário. Sequências retro-transposônicas foram desenvolvidas por apresentarem maior rendimento de transformação genética (HODGSON et al., 1996). Contudo, a comparação entre vetores revelou que sequências transposônicas apresentam letalidade dose dependentes (altas concentrações do vetor causam alta letalidade embrionária). Em contrapartida, seqüências virais são compatíveis com o desenvolvimento embrionário, mesmo em altas concentrações (SCIAMANNA et al., 2000). Estes dados demonstram que o tipo de vetor e respectiva dose podem influenciar nos protocolos de TGME.

Pelo fato desta biotécnica utilizar mecanismos fisiológicos há grande interesse em seu desenvolvimento, pois gerar um animal transgênico está além de introduzir uma seqüência de DNA exógeno de interesse em um genoma. É necessário que o gene seja incorporado ao genoma, sem causar danos, para que o embrião possa se desenvolver e originar um organismo funcional.

Levando em consideração esta definição, a eficiência e a repetibilidade da TGME é controversa, necessitando de maiores esforços para compreender os mecanismos na incorporação e na expressão do transgene. As taxas de transgenia descritas para bovinos, por exemplo, utilizando esta técnica variam de $2,4 \%$ à $22 \%$, demonstrando que diferentes condições laboratoriais, variabilidade individual e tipo de técnica utilizada, influenciam nos resultados da TGME.

Durante o processo de penetração espermática, as moléculas de DNA aderidas à membrana do espermatozóide são removidas ainda na superfície do oócito (Figura 3), penetrando neste apenas porções de membrana espermática livres de DNA (CHAN et al., 2000). Este fenômeno corrobora com a hipótese de que a transmissão do DNA exógeno ocorra, preferencialmente, quando este está no núcleo da célula espermática. 


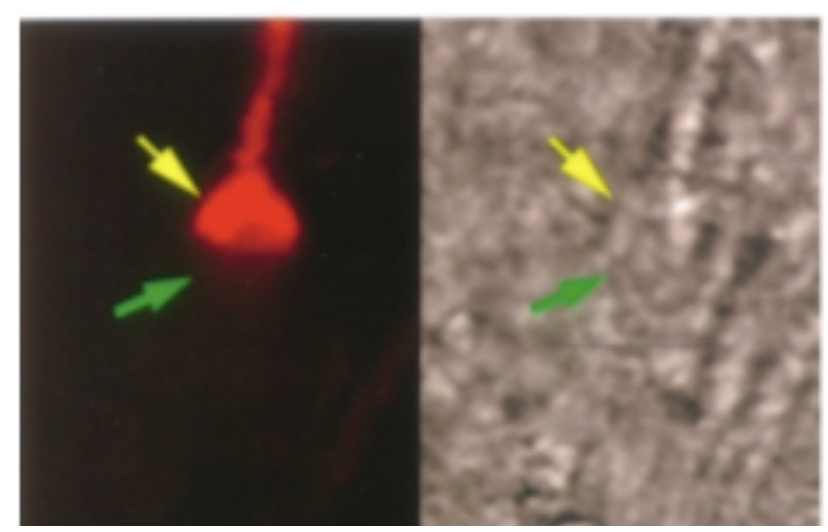

Figura 3 Espermatozóide de Macaco Rhesus durante o processo de fecundação in vitro. À esquerda, DNA plasmidial marcado com rodamina é removido, na superfície do oócito, durante a FIV (seta amarela). O espermatozóide parcialmente penetrado demonstra a perda do DNA plasmidial em sua porção interiorizada (seta verde). À direita, imagem do mesmo plano focal. Fonte: Chan et al. (2000).

Na tentativa de elucidar qual é o mecanismo de transmissão das moléculas exógenas de DNA pelos espermatozóides, alguns autores adicionaram à técnica uma etapa de tratamento com DNAse I, com o intuito de remover as moléculas de DNA não interiorizados nas células espermáticas (RIETH et al., 2000; GAGNE et al., 1991). Os resultados sugerem que a veiculação das moléculas de DNA provavelmente ocorra por uma via intracelular.

Para investigar de forma mais precisa qual o mecanismo de veiculação das moléculas exógenas de DNA nos protocolos de TGME é faz-se necessário o emprego de técnicas de hibridização de ácidos nucléicos em espermatozóides e embriões tratados com DNA exógeno.

A hibridização in situ (FISH) é uma técnica de hibridização de ácidos nucléicos que possibilita o estudo de um genoma por completo ou porções dele, um único loci (VORSANOVA et al., 2010). De modo geral, as sondas utilizadas nesta técnica podem ser classificadas de acordo com a sequência alvo para qual foram desenhadas, sondas telomérias, ponto-específico ou pintura de cromossomo completo (VORSANOVA et al., 2008). 


\section{HIPÓTESE}

A técnica de hibridização in situ, somada a melhor compreensão dos mecanismos celulares e moleculares envolvidos no processo de TGME, pode ser uma ferramenta útil para estudar a veiculação do transgene em espermatozóides e embriões bovinos. 


\section{OBJETIVOS}

Os objetivos foram divididos em dois tópicos, gerais e específicos, que seguem:

\subsection{Objetivos Gerais}

O presente trabalho visa avaliar o efeito de diferentes doses e métodos de transfecção sobre a viabilidade de espermatozóides bovinos e avaliar a existência de um sitio preferencial de ligação deste transgene em espermatozóides e embriões.

\subsection{Objetivos específicos}

- Quantificar o número de cópias de DNA captadas e interiorizadas pelas células espermáticas.

- Avaliar as alterações de membrana plasmática, acrossomal e mitocondrial causadas durante o processo de TGME.

- Verificar o índice de fragmentação de DNA de espermatozóides após a TGME.

- Localizar o inserto no genoma espermático.

- Acompanhar o perfil eletroforético das proteínas espermáticas durante os protocolos de TGME, para verificar a presença do IF-1.

- Avaliar o potencial de fecundação e de desenvolvimento in vitro de embriões.

- Analisar a expressão do gene marcador da EGFP nos embriões.

- Avaliar os índices de transfecção nos embriões produzidos com espermatozóides tratados

- Verificar a localização do inserto no genoma de espermatozóides e de embriões produzidos in vitro. 
Com intuito de obter informações mais precisas dos mecanismos da TGME, dois experimentos foram propostos tendo o experimento 1 o enfoque nos espermatozóides e o experimento 2, enfoque nos embriões.

\subsection{Experimento 1 - Estudo dos efeitos da TGME em espermatozóides bovinos}

Este experimento foi delineado para compreender os efeitos dos protocolos de TGME nas células espermáticas bovina. Visualizar qual a porcentagem de moléculas de DNA captadas e interiorizadas pelos espermatozóides nos protocolos de TGME. O efeito que os métodos de transfecção podem causar nas principais organelas espermáticas, a localização topográfica do inserto no genoma do espermatozóide e o comportamento do perfil protéico durante os protocolos de TGME.

Na tentativa de responder estas questões foi realizado a técnica de PCR em tempo real para quantificar as moléculas DNA aderidas e interiorizadas nos espermatozóides (item 5.1.1). A técnica de citometria de fluxo para avaliar os efeitos dos protocolos de TGME na integridade das membranas plasmática (item 5.1.2.1) e acrossomal (item 5.1.2.1) e o potencial de membrana mitocondrial (item 5.1.2.2) de espermatozóides bovinos; e o efeito deste protocolo no índice de fragmentação de DNA espermático (item 5.1.2.3).

A procura e localização do inserto no genoma espermático foi realizado pela técnica de hibridização in situ (item 5.1.3). Para avaliar a influência do Fator Inibitório I nos protocolos de TGME em bovinos foi realizado perfil protéico por SDS-PAGE (item 5.1.4). A Figura 4 esquematiza o delineamento experimental proposto. 


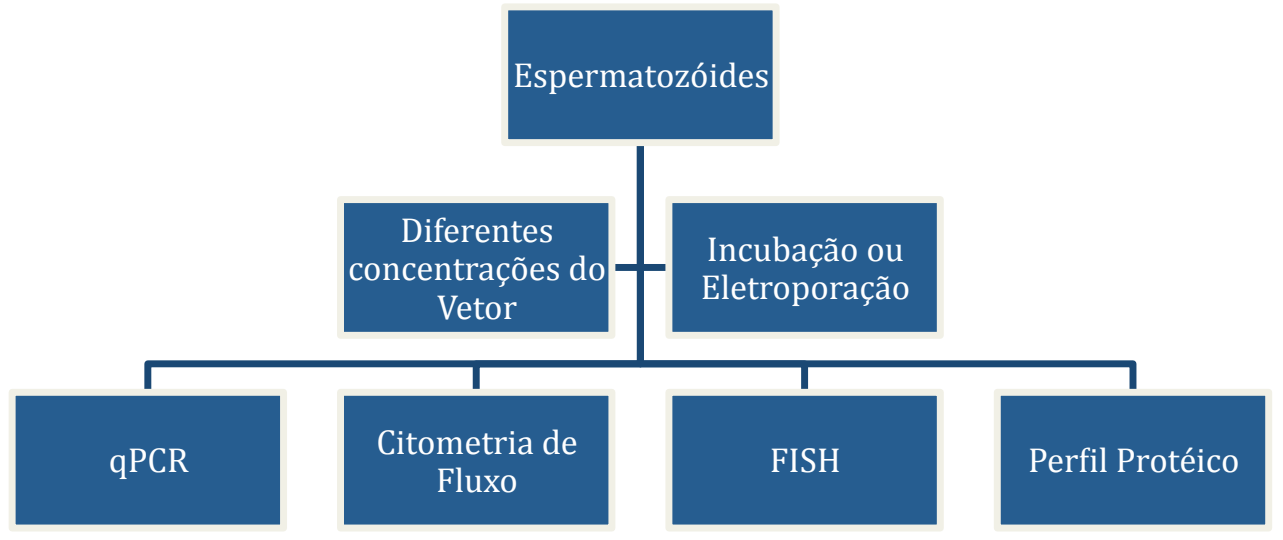

Figura 4 Modelo gráfico do delineamento experimental do experimento 1. Este experimento visa avaliar o efeito de diferentes concentrações de DNA e dos diferentes tratamentos (incubação e eletroporação) para a integração do DNA na viabilidade espermática utilizando técnicas de PCR em tempo real, de citometria de fluxo, de hibridização in situ e o perfil protéico por SDS-PAGE.

Para cada uma destas análises, três palhetas de sêmen de touros distintos foram descongeladas em água a $37^{\circ} \mathrm{C}$ por 30 segundos. As palhetas foram secas com papel toalha e o conteúdo transferido cuidadosamente para tubos de microcentrífuga de $1,7 \mathrm{ml}$, contendo gradiente de Percoll ${ }^{\circledR}$ (45 e 90\%) (Sigma, $\mathrm{n}$. $\mathrm{P} 1644-11)$. Estas amostras foram centrifugadas por $5 \mathrm{~min}$ a $9.000 \mathrm{x} \mathrm{g}$ (centrifuga $5415 \mathrm{R}$ Eppendorf) e o sedimento celular transferido para tubos de $1,7 \mathrm{ml}$ contendo $400 \mu \mathrm{l}$ de meio TALP Sêmen (Anexo C).

As células foram mecanicamente suspensas e novamente centrifugadas a $9.000 \times \mathrm{g}$ por $2 \mathrm{~min}$, para a remoção de resíduos do Percoll ${ }^{\circledR}$. Uma fração de $50 \mu \mathrm{l}$ destes sedimentos foi transferida para tubos de $1,7 \mathrm{ml}$. Foram aferidas a concentração espermática por contagem em câmera de Neubauer (diluição 1:50 em água) e a motilidade espermática por observação em microscópio de contraste de fase, de cada um desses sedimentos espermáticos. Amostras com motilidade inferior a $80 \%$ ou concentração inferior a $610^{6} \mathrm{cel} / \mathrm{ml}$ foram desprezadas. Os sedimentos foram ajustados para a concentração final de $10^{6} \mathrm{cé} / \mathrm{s} / \mathrm{ml}$ com a adição de meio TALP Sêmen. Foram misturados $1 \mathrm{ml}$ de cada uma destas suspensões de 
concentração ajustada para formar uma mistura homogênea (pool) de $3 \mathrm{ml}$, no qual cada touro contribuiu igualmente com $10^{6}$ células. $O$ pool foi dividido em quatro frações de $750 \mu$ l, sendo adicionado três concentrações distintas de DNA (250, 500 ou $1000 \mathrm{ng}$ ), para cada $10^{6}$ células espermáticas e um controle negativo.

O vetor recombinante utilizado foi o pCX-EGFP, linearizado com enzima de restrição HindIII (Apêndice 1). Após a adição das distintas concentrações de DNA foram empregados dois métodos de transfecção, a incubação simples por 30 min a $37^{\circ} \mathrm{C}$ ou o emprego de eletroporação (Eppendorf Multiporator), em câmara de 4 $\mathrm{mm}$ com pulso único de 300V, $35 \mu \mathrm{F}$ por 0,25 mseg (GAGNE et al., 1991). Ao termino do período de incubação, $6 \mathrm{U}$ de Desoxyribonuclease I (Invitrogen Corporation (C) Cat. No. 18047-019) foram adicionadas em todos os grupos experimentais (grupos incubação, eletroporação e controle).

O experimento foi realizado em triplicata (3 replicatas técnicas), sendo utilizado palhetas de sêmen dos mesmos touros e das mesmas partidas. Pequenas adaptações para cada análise foram realizadas e estão descritas pormenorizadamente em seus respectivos itens.

\subsubsection{Quantificação da captação espermática de moléculas DNA}

Após o Protocolo de TGME, descrito no item 5.1, as amostras dos distintos tratamentos foram divididas, para que metade dos espermatozóides $\left(0,5 \times 10^{6}\right.$ células) passassem pelo tratamento com DNAse I, e a outra metade não. Deste modo, com o tratamento com DNAse I, as moléculas de DNA aderidas à membrana dos espermatozóides foram removidas, restando apenas as moléculas interiorizadas.

A inativação da DNAse I foi feita por desnaturação térmica à $70^{\circ} \mathrm{C}$ por 30 minutos em termociclador (Mastercicler ${ }^{\circledR}$ Eppendorf). As amostras que não sofreram o tratamento com DNAse I foram centrifugadas a $14.000 \times \mathrm{g}$ por $10 \mathrm{~min}$. O sobrenadante foi descartado e adicionado novamente o mesmo volume de meio 
TALP Sêmen. Com este procedimento, as moléculas de DNA exógeno, não aderidas às membranas dos espermatozóides foram removidas, permanecendo apenas as moléculas ligadas às células.

Em seguida foi realizada a extração de DNA pelo método de fenolclorofórmio descrito por HOELKER et al. (2007). A quantificação da concentração de DNA total foi feita por espectrofotometria (Nanodrop ND-1000, NanoDrop Technologies, inc, USA). As amostras de DNA foram ajustadas para $20 \mathrm{ng} / \mathrm{\mu l}$, sendo utilizadas 200 ng de DNA na reação de qPCR.

A reação de qPCR foi feita em duplicata utilizando o kit SYBR GreenER qPCR Super Mix (Invitrogen Corporation@, Cat. No.11762-100), os primers GFP/F (ATGGCCGACAAGCAGAAGAAC) e GFP/R (TGCCGTCCTCGATGTTGTG) e o termociclador em tempo real (Realplex ${ }^{\circledR}$ Eppendorf). As condições da reação podem ser observadas na Figura 5.

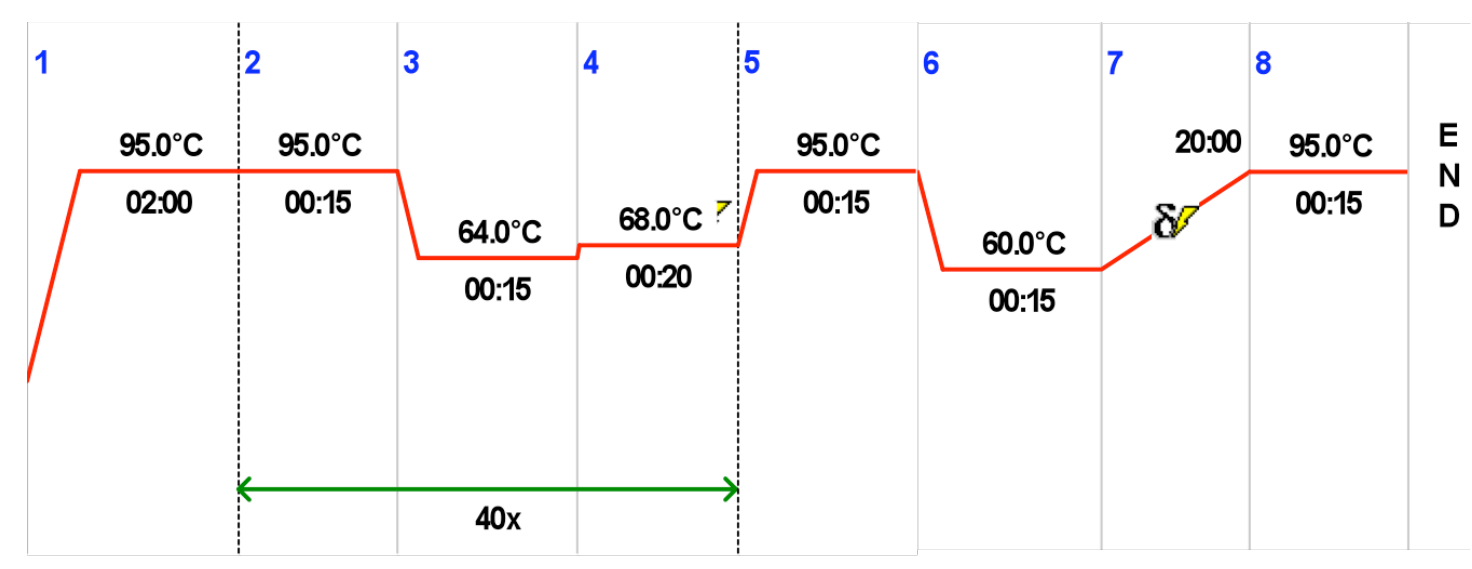

Figura 5 Descrição gráfica da relação temperatura pelo tempo da reação de qPCR. Passo 1 corresponde a desnaturação do DNA e ativação DNA polimerase. Passos de 2 a 4 correspondem ao ciclo da reação, o qual foi repetido por 40 vezes. Passos de 5 a 8 correspondem a curva de dissociação.

Para a quantificação do número de cópias de DNA amplificadas foi feita uma curva controle de amplificação por diluição seriada (1:10) do plasmídio pCX-EGFP. A curva teve início com 2 ng de vetor e término na sexta diluição. Isso corresponde a uma curva que parte de 8.257.713 cópias do vetor e tem seu término com 82 cópias. 
5.1.2 Efeito de protocolos de TGME em organelas espermáticas

Com o intuito de avaliar o efeito dos protocolos de TGME nas organelas espermáticas foi realizada a técnica de citometria de fluxo utilizando o equipamento Guava Easycyte mini (Guava Technologies, Hayward, CA, USA) (processo FAPESP N ${ }^{0}$ 07/55294-8).

Foram utilizadas sondas fluorescentes para marcar a integridade da membrana plasmática (item 5.1.2.1), da membrana do acrossomal (item 5.1.2.1), o potencial de membrana mitocondrial (item 5.1.2.2) e a fragmentação de DNA genômico (item 5.1.2.3) dos espermatozóides, após protocolo de TGME (item 5.1).

Foram avaliadas 10.000 células da população de espermatozóides para cada sonda utilizada.

\subsubsection{Avaliação da integridade das membranas plasmática e acrossomal}

Para verificar a integridade das membranas plasmática e acrossomal dos espermatozóides tratados (item 5.1) foi utilizada a coloração dupla com iodeto de propídio (PI) (Sigma, Cat. No. 28707-5) juntamente com aglutinina de Psium sativum conjugada com isioticionato de fluoresceína (FITC-PSA) (Sigma, Cat. No. C-0770 ).

A membrana plasmática íntegra é impermeável ao PI. Nos espermatozóides com membrana plasmática lesada, o PI penetra na célula, corando o núcleo que fluoresce em vermelho. A aglutinina de Psium sativum conjugada com isioticionato de fluoresceína (FITC-PSA) fluoresce em verde a região do acrossomo dos espermatozóides que sofreram reação acrossomal.

A análise do espermatozóide pelo uso simultâneo destas sondas fluorescentes resulta na visualização de quatro populações celulares distintas: 1) população de célula sem qualquer tipo de lesão; 2) células com lesão na 
membrana acrossomal; 3) células com lesão na membrana citoplasmática e 4) células com lesão em ambas as membranas (Apêndice 10.3).

Para isso foram adicionados $40 \mu \mathrm{l}$ de FITC-PSA $(100 \mu \mathrm{g} / \mathrm{ml})$ e $180 \mu \mathrm{l}$ de Azida sódica $10 \%$ às amostras tratadas (item 5.1) e incubadas a $37^{\circ} \mathrm{C}$ por 10 minutos. Transcorrido este tempo de incubação foi adicionado $3 \mu \mathrm{l}$ de PI $(25 \mu \mathrm{g} / \mathrm{ml})$, sendo então as amostras centrifugadas a $6.000 \mathrm{~g}$ por 2 min e ressuspendidas em PBS. Após este procedimento, as amostras foram avaliadas no citômetro de fluxo.

\subsubsection{Avaliação do potencial de membrana mitocondrial}

A função mitocondrial foi verificada utilizando a sonda JC-1 (Molecular Probes, Cat. No. T-3168), que cora em vermelho as mitocôndrias com alto potencial de membrana e em verde as com baixo potencial (MARTINEZ-PASTOR et al., 2004). Duas populações celulares bem delimitadas podem ser observadas no dotplot de fluorescência vermelho (eixo y) pelo verde (eixo x). Células com alto potencial de membrana mitocondrial (APMM) formam a população detectada no canto superior do dotplot e células com baixo potencial de membrana mitocondrial (BPMM) foram detectadas no canto inferior do dotplot. Entre estas duas populações celulares existem as células com intermediário potencial de membrana mitocondrial, no entanto, esta população celular apresenta maior dispersão, formando rastro (Apêndice 10.3).

Para esta avaliação foi adicionado $2 \mu \mathrm{l}$ de JC-1 (153 $\mu \mathrm{M})$ às amostras tratadas (item 5.1) e incubadas a $37^{\circ} \mathrm{C}$ por $5 \mathrm{mim}$. Transcorrido este tempo de incubação, as amostras foram centrifugadas a $6.000 \times \mathrm{g}$ por 2 minutos e ressuspendidas em PBS. Após este procedimento as amostras foram analisadas pelo citômetro de fluxo. 


\subsubsection{Avaliação da fragmentação de DNA em espermatozóides}

O ensaio de estrutura de cromatina espermática (do inglês, sperm cromatin structure assay - SCSA) avalia a susceptibilidade da célula em sofrer fragmentação do DNA utilizando a sonda fluorescente Laranja de Acridina (Molecular Probes, Cat. No. A1301). Esta sonda apresenta permeabilidade à célula espermática e intercala-se ao DNA, fluorescendo do espectro verde ao vermelho (excitação 502 nm e emissão em $650 \mathrm{~nm}$ ), de acordo com o grau de compactação da cromatina. Diferentemente das sondas descritas anteriormente, a análise da fragmentação de DNA espermático é realizada indiretamente pelo programa FlowJo (Flow Cytometry Analysis Software - Tree Star Inc., Ashland, Oregon, USA). Foi calculado o AlfaT de cada amostra, expressão resultante da razão da fluorescência vermelha pela fluorescência total $[\alpha \mathrm{T}=$ amarelo/(amarelo+verde)]. A porcentagem de DNA desnaturado da amostra é marcada manualmente à partir do histograma de $\alpha \mathrm{T}$ e recebe o nome de $\mathrm{COMP} \alpha \mathrm{T}$ (do inglês, cells outside the main population). Foi adotado como referência, os mesmos valores descritos por Evenson e Jost (2000) para humanos, no qual COMP $\alpha \mathrm{T}$ entre $0-15 \%$ é considerado baixo índice de fragmentação (alta fertilidade), entre 16-29\% médio índice de fragmentação e $\geq 30 \%$ alta fragmentação (baixa fertilidade) - Apêndice 10.3.

Resumidamente, alíquotas de sêmen (item 5.1) foram diluídas para um volume total de 200 ul com tampão TNE (ANEXO 4) e concentração de $2 \times 10^{6}$ células $/ \mathrm{ml}$. Imediatamente após, $0,40 \mathrm{ml}$ de solução detergente ácida (ANEXO 4) foram adicionados. Após 30 segundos, adicionou-se 0,6 ml de solução de laranja de acridina (LA) contendo $6 \mathrm{ug}$ LA/ml de tampão (Sigma, St. Louis, MO, E.U.A ANEXO 4). As amostras foram analisadas por citometria de fluxo. 
5.1.3 Análise topográfica do inserto no genoma espermático

Para a realização da técnica de hibridização in situ foram construídas sondas marcadas a partir do vetor recombinante pCX-EGFP. Fragmentos de 100 $500 \mathrm{pb}$ do vetor recombinante pCX-EGFP foram gerados pelo corte da enzima de restrição DNAse I (Promega cat. no. 16834801) após 6 horas de incubação a $15^{\circ} \mathrm{C}$. Foi utilizado o kit de marcação com digoxigenina DIG-nick Translatiom Mix (Roche Diagnóstica Brasil Ltda, cat. No. 11745816910), o qual adiciona uma nova cadeia de DNA marcado com Digoxigenina - dUTP (20 - 25 bases) nas extremidades livres dos fragmentos gerados (Apêndice 10.4).

Para o reconhecimento dos sítios de integração do transgene, no genoma dos espermatozóides e/ou embriões foi utilizado conjugados Anti-Digoxigenina-AP (Roche Diagnóstica Brasil Ltda, cat. No. 11093274 910).

O sistema de detecção utilizado para revelar os pontos de hibridização foi o HNPP Fluorescent Detection Set (Roche Diagnóstica Brasil Ltda, cat. No. 11758 888 001). Neste sistema, a enzima fosfatase-alcalina catalisa a reação de defosforização do substrato NHPP, em precipitados com alto grau de fluorescência.

Antes de iniciar a hibridização in situ, os espermatozóides tratados foram submetidos a duas pré-lavagens a 400 x g por 10 min, seguidas de remoção do sobrenadante. Posteriormente, a concentração espermática foi ajustada para 2,5 x $10^{8}$ células por $\mathrm{mL}^{-1}$ utilizando diluente TRIS $(0,01 \mathrm{~mol}$ Tris e $0,9 \%$ de $\mathrm{NaCl})$.

O protocolo para a descondensação dos espermatozóides baseia-se no método descrito por Rens et al. (2001), no qual os espermatozóides foram submetidos a uma congelação rápida por imersão direta em nitrogênio líquido e descongelação rápida a $37^{\circ} \mathrm{C}$. Após esta etapa, os espermatozóides foram fixados em lâmina e submetidos à ação química e enzimática para a fixação dos cromossomos.

As sondas marcadas foram então termo-desnaturadas $\left(70^{\circ} \mathrm{C}\right.$ por $\left.10 \mathrm{~min}\right) \mathrm{e}$ colocadas sobre a lâmina contendo o DNA dos espermatozóides descondensados. Após este período, as lâminas foram lavadas sucessivamente com Solução SSC, 
para a remoção das sondas não hibridizadas. A leitura da lâmina foi feita em microscópio de epifluorescência, com aumento de 400 vezes.

Como controle positivo das hibridizações foi utilizada sonda telomérica marcada com FITC (fluorescência verde) construída a partir dos primers (TTAGGG)5 e (CCCTAA)5 conforme descrito por ljdo et al. (1991b).

5.1.4 Análise do perfil eletroforético das proteínas do plasma seminal

$\mathrm{Na}$ tentativa de observar a ação do Fator Inibitório-1 sobre as células espermáticas foi realizado o perfil eletroforético das proteínas seminais. Após a separação por gradiente Percoll ${ }^{\circledR}$, amostras $(50 \mu \mathrm{l})$ do conteúdo da palheta de sêmen, de cada fase do gradiente Percoll ${ }^{\circledR}$, do meio de lavagem das células espermáticas e do sedimento espermático final foram recolhidas. A Figura 6 exemplifica as fases do gradiente Percoll ${ }^{\circledR}$, do qual foram captadas as amostras para a realização da SDS-PAGE.

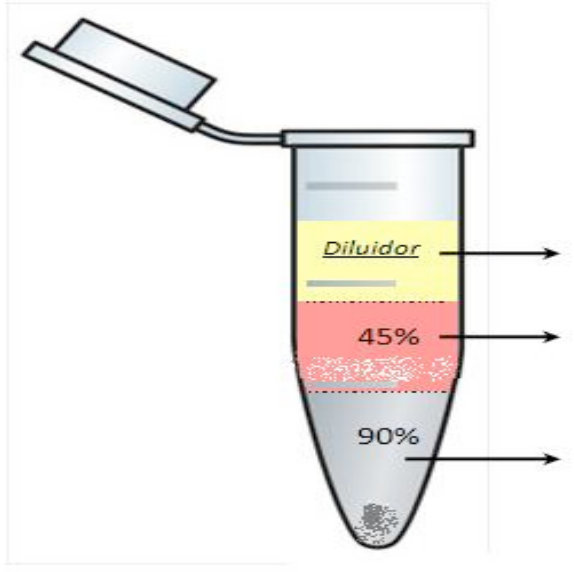

Fase 1
Fase 2
Fase 3

Figura 6 Desenho esquemático do gradiente Percoll ${ }^{\circledR}$. As setas indicam as fases onde foram retiradas amostras para a realização do perfil eletroforético das proteínas seminais. Amarelo $=$ fase $1 ;$ vermelho $=$ Fase 2; cinza $=$ Fase 3.

As amostras protéicas foram centrifugadas a $1000 \times \mathrm{g}$ por 10 minutos a $4^{\circ} \mathrm{C}$ e o sobrenadante transferido para um novo tubo. A concentração protéica deste 
material foi aferida por espectofotometria (Nanodrop ND-1000, NanoDrop Technologies, inc, USA). Foram adicionados $25 \mu \mathrm{l}$ de Tampão de Amostra (Glycerol; Tris-Hcl 0,6173M - $\mathrm{pH} \quad 6,8 ; \beta$-mercaptoethanol; $10 \%$ SDS; bromophenolblue; $\mathrm{H} 2 \mathrm{O}$ ) e estas fervidas por $10 \mathrm{mim}$ a $100{ }^{\circ} \mathrm{C}$.

A eletroforese foi realizada em tampão Tris (LAEMMLI et al., 1970), utilizando gel de $15 \%$. As amostras foram concentradas durante 20 minutos a $60 \mathrm{~V}$ e a separação realizada por $12 \mathrm{~h}$ a $120 \mathrm{~V}$. Foi utilizado marcador de peso molecular in house e plasma seminal de touro controle não criopreservado. A revelação do gel foi realizada pela coloração de Coomassie Brilliant Blue (BAAS et al., 1983).

\subsection{Experimento 2 - Produção in vitro de embriões com uso de espermatozóides tratados com DNA exógeno}

Este experimento foi delineado para avaliar a fertilidade dos espermatozóides após protocolos de TGME na produção in vitro (PIV) de embriões bovinos.

Para isso, a concentração de 1000 ng de vetor recombinante foi utilizada para cada $10^{6}$ células espermáticas (experimento 1 ) e os dois métodos de transfecção (incubação e eltroporação). Os espermatozóides foram preparados com a mesma metodologia descrita no item 5.1, passando pelo tratamento com DNAse I. Estas células foram submetidas ao protocolo de produção in vitro de embriões, sendo avaliadas as taxas de clivagem e de blastocisto (item 5.2.1). Os embriões resultantes deste processo foram avaliados quanto à expressão do gene marcador da EGFP (item 5.2.2), presença do gene (item 5.2.3) e análise topográfica do inserto (item 5.2.4). A Figura 7 se refere ao delineamento experimental do experimento 2 . 


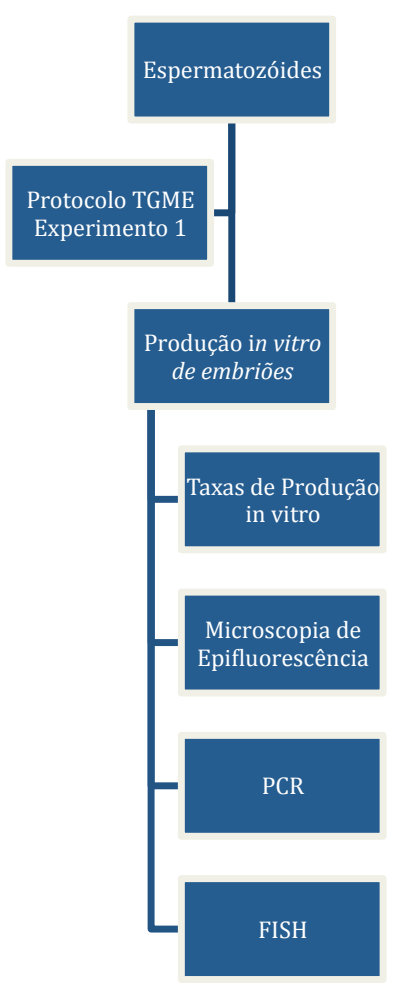

Figura 7 Modelo gráfico do delineamento experimental do Experimento 2. Este experimento avalia o efeito dos protocolos de TGME sobre o potencial de produção e desenvolvimento in vitro de embriões. No processo de PIV foram avaliadas as taxas de clivagem, blastocisto e eclosão. Os embriões resultantes da PIV foram avaliados quanto a expressão do gene marcador da EGFP (microscopia de epifluorescência), presença do gene (PCR) e localização do inserto (FISH).

5.2.1 Potencial de produção e desenvolvimento in vitro de embriões

A fecundação in vitro foi realizada com oócitos obtidos de animais recém abatidos em matadouro comercial, seguindo protocolo padrão do Laboratório de Fecundação in vitro, Clonagem e Transgenia Animal da Faculdade de Medicina Veterinária e Zootecnia da Universidade de São Paulo.

Após o abate dos animais, os ovários foram acondicionados em recipiente térmico contendo solução fisiológica a $30^{\circ} \mathrm{C}$ e transportados para o laboratório. Neste, os ovários foram lavados, por duas vezes, com solução fisiológica aquecida $\left(30^{\circ} \mathrm{C}\right)$.

Os oócitos foram obtidos por aspiração folicular, com seringa de $5 \mathrm{ml}$ e agulha $21 \mathrm{G}$, e mantidos em tubo cônico de $15 \mathrm{ml}$ por 10 minutos para a 
decantação do líquido folicular. O sedimento foi recuperado e avaliado em estereomicroscópio. Os oócitos foram selecionados e transferidos para o meio de lavagem (Anexo 1). A maturação in vitro (MIV) destas estruturas ocorreu durante 22-24 horas de incubação em meio de maturação em estufa de $5 \%$ de $\mathrm{CO}_{2}$ em ar a $38,5^{\circ} \mathrm{C}$ e alta umidade (Anexo 1 ).

A fecundação in vitro (FIV) foi realizada utilizando espermatozóides tratados (item 5.2). Após a transfecção (item 5.1) foram retiradas duas amostras de $5 \mu$ l para determinação da concentração e avaliação da motilidade dos espermatozóides em lâmina sob microscópio óptico de luz. A concentração foi determinada em câmara de Neubauer, diluindo-se $5 \mu$ l do sedimento em $250 \mu l$ de água e a motilidade avaliada em microscópio óptico de luz (200x) após diluição de $5 \mu$ l do sedimento em $250 \mu$ l do meio FIV-Gota (Anexo 2).

Os espermatozóides foram diluídos no meio FIV-Gota na concentração final de $10^{6}$ espermatozóides $/ \mathrm{ml}$. As microgotas de meio de fecundação contendo os oócitos maturos (20 a 30) foram inseminadas com $10^{6}$ espermatozóides/ml (Anexo 2). Os gametas foram incubados durante 18h, em estufa a $38,5^{\circ} \mathrm{C}, 5 \%$ de $\mathrm{CO}_{2}$ em ar e alta umidade para fecundação in vitro (FIV).

Após o período de FIV, os presumíveis zigotos foram desnudados pela remoção mecânica das células do cumullus por pipetagem sucessiva (Anexo 3) e colocados em microgotas contendo 90ul de meio SOFaa para o cultivo in vitro (CIV) dos embriões (Anexo 3), O cultivo in vitro foi realizado em estufa a $38,5^{\circ} \mathrm{C}$, $5 \%$ de $\mathrm{CO}_{2}$ em ar e alta umidade, durante 9 dias consecutivos.

Foram avaliadas as taxas de clivagem (estádios de 2 a 8 células) às 72 horas de cultivo e de desenvolvimento embrionário no $7^{\circ}, 8^{\circ}$ e $9^{\circ}$ dias, classificando-os de acordo com o estádio embrionário (mórula, mórula compacta, blastocisto inicial, blastocisto, blastocisto expandido e blastocisto eclodido). 
5.2.2 Avaliação da expressão do gene marcador em embriões produzidos in vitro

As estruturas embrionárias foram observadas em microscópio invertido de fluorescência (Olympus IX81) sob a excitação da luz ultravioleta com filtro de 480 507 nanômetros para avaliar a expressão do gene repórter EGFP. Estas estruturas foram analisadas e fotografadas com aumento de 100 ou 200 vezes.

5.2.3 Análise da presença do gene marcador em embriões produzidos in vitro

A detecção do vetor pCX-EGFP nos embriões foi feita por reação em cadeia da DNA polimerase utilizando o kit Platinum Taq DNA polimerase (Invitrogen Cat. No. 10966-026). Primariamente, os embriões sofreram remoção mecânica da zona pelúcida e consequente remoção de possíveis espermatozóides aderidos a esta. Foram lavados por três vezes em gotas de $10 \mu \mathrm{l}$ de PBS e acondicionados individualmente em tubos de $0,2 \mathrm{ml}$, sendo estes congelados a $-20^{\circ} \mathrm{C}$ até 0 momento da avaliação. As reação seguiram as mesmas condições descritas no item 5.1.1, que resulta na amplificação de um fragmento de 67 pares de base da seqüência codificadora do gene da EGFP.

5.2.4 Análise topográfica do inserto em embriões produzidos in vitro

Os embriões gerados a partir dos espermatozóides transfectados (item 5.2) foram lavados em PBS por três vezes e transferidos para gotas de $2 \mu$ l (PBS) em lâminas pré-tratadas com metanol. Para a remoção da zona pelúcida uma gota de $2 \mu \mathrm{l}$ de solução $0,01 \mathrm{M} \mathrm{HCl}, 0,1 \%$ Tween 20 em água DPC foi adicionada sobre os embriões. Posteriormente as lâminas foram secas em temperatura ambiente e estocadas $\mathrm{a}-20^{\circ} \mathrm{C}$. 
O procedimento de hibridização in situ seguiu a metodologia descrita por Whyte et al. (2000). As lâminas contendo os embriões fixados foram desidratadas em metanol $80 \%$ a $-20^{\circ} \mathrm{C}$ por 20 minutos, secas por 1 hora ao ar e incubadas em solução de pepsina $(100 \mu \mathrm{g} / \mathrm{ml}$ de pepsina em $0,01 \mathrm{M} \mathrm{HCl})$ a $37^{\circ} \mathrm{C}$ por 20 minutos. Para a remoção desta solução, o material foi lavado três vezes em $500 \mu \mathrm{l}$ de $2 x$ SSC e novamente secas em ar por 20 minutos. Após este período foi realizada nova desidratação com metanol $80 \%$ a $-20^{\circ} \mathrm{C}$ por 20 minutos. Para a hibridização in situ, os embriões foram desnaturados por 3 minutos a $75^{\circ} \mathrm{C}$, sendo adicionadas as sondas de hibridização, também desnaturadas (item 5.1.3) e incubados em câmera úmida por 18 horas a $37^{\circ} \mathrm{C}$. A leitura da lâmina foi feita em microscópio de epifluorescência com aumento de 400 vezes.

\subsection{Análise estatística}

As análises estatísticas foram feitas utilizando o programa SAS System for Windows (SAS institute inc., Cary, NC, USA). Através do aplicativo Guided Data Analisys, os dados foram testados quanto à normalidade dos resíduos e homogeneidade das variâncias. Quando não obedeceram estas premissas, foram transformados para logaritmo na base 10. Para a descrição dos resultados foram empregadas as médias com respectivos erros padrões (média \pm erro padrão da média) e os níveis de significância $(p)$ dos dados originais.

Foi empregado o procedimento GLM (General Linear Models) para a análise de variância, observando os efeitos principais e as possíveis interações. O teste utilizado para a comparação de médias foi o Limit state design (LSD) para variáveis com três tratamentos ou teste $\mathrm{T}$ de Student para variáveis com dois tratamentos, ambos com nível de significância de 5\%. 
Os resultados e discussão foram sub-divididos de acordo com 0 experimento realizado para melhor apresentação dos dados experimentais.

\subsection{Experimento 1 - Estudo dos efeitos da TGME em espermatozóides bovinos}

Devido a diversidade de técnicas utilizadas neste experimento os resultados foram divididos por análise.

\subsubsection{Quantificação da captação espermática de moléculas DNA}

Os resultados das curvas de amplificação estão descritos na Figura 8. Não houve interação entre os fatores avaliados (concentração de DNA, método de transfecção, adição ou não de DNAse sobre o número de cópias amplificadas de 200 ng de DNA total, extraídos de espermatozóides (Tabela 1). Assim, os dados foram analisados levando-se em conta cada um dos fatores separadamente; adição ou não de DNAse I (Figura 9), quantidade de DNA utilizado (0, 250, 500 e 1000 ng; Figura 10), e métodos de transfecção (incubação e eletroporação; Figura 11). 
Tabela 1 Efeito da concentração de DNA $(0,250,500,1000 \mathrm{ng})$, do método de transfecção (incubação, eletroporação), da adição ou não de DNAse e respectivas interações sobre o $\mathrm{n}^{\circ}$ de cópias amplificadas de $200 \mathrm{ng}$ de DNA total, extraído de espermatozóides.

DNA Eletro DNAse DNAxEletro DNAxDNAse EletroxDNAse DNAxEletroxDNAse

\begin{tabular}{lllllll}
\hline 0,3176 & 0,2037 & $<, 0001$ & 0,8832 & 0,2978 & 0,2206 & 0,8924
\end{tabular}

A Figura 8 mostra, de forma descritiva, os valores médios do número de cópias amplificadas nos distintos tratamentos. Podemos notar que espermatozóides tratados com DNAse I apresentam entre 32.000 (máximo) e 13.000 (mínimo) cópias do vetor para cada 200ng de DNA total extraído. Células espermáticas não tratadas com DNAse I apresentam entre 1.000 .000 (máximo) e 360.000 cópias para cada 200 ng de DNA total extraído.

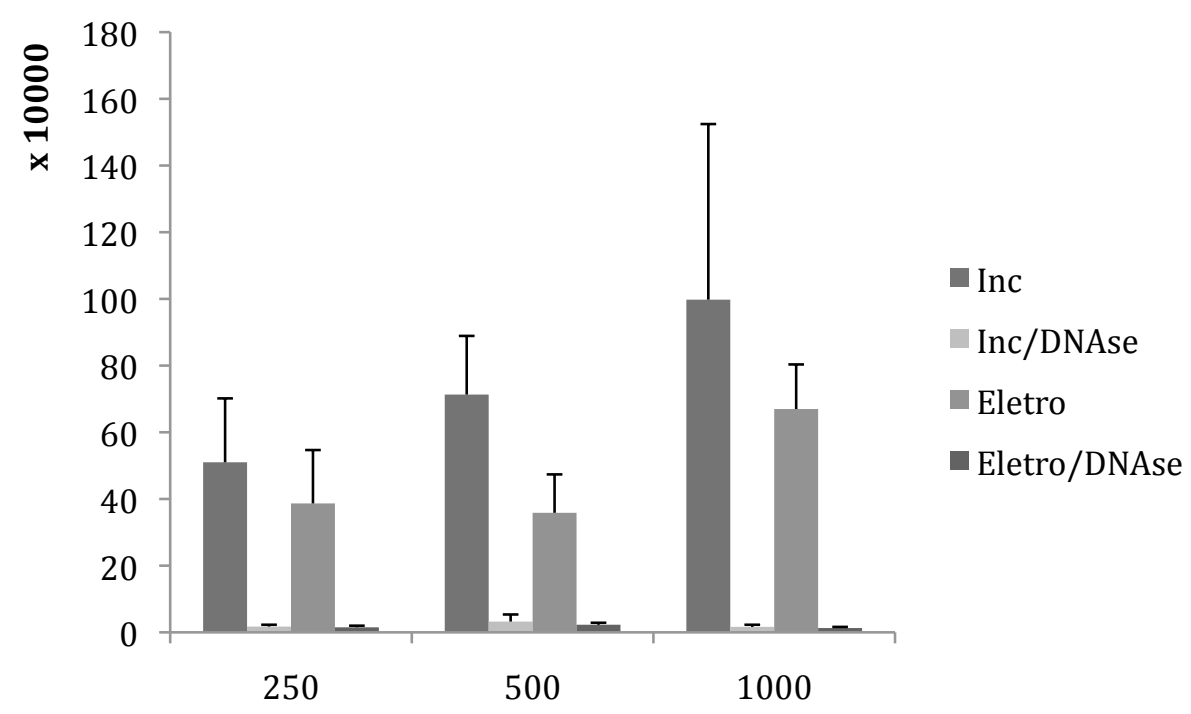

Figura 8 Valores médios e erro padrão da média do número de cópias do fragmento amplificado em tempo real, para cada $200 \mathrm{ng}$ de DNA total dos espermatozóides, nos distintos tratamentos. Inc = espermatozóides apenas incubados com o vetor pCX-EGFP; Inc/DNAse = espermatozóides do grupo Inc após tratamento com DNAse I; Eletro = espermatozóides incubados com DNA exógeno e depois eletroporados; Eletro/DNAse = espermatozóides do grupo Eletro após tratamento com DNAse I.

Como pode ser observado na Figura 9, o tratamento com DNAse I induziu uma diminuição no número de cópias quando comparado com amostras não tratadas $(P<0,0001)$. Este resultado sugere que a utilização da DNAse I foi eficiente para a remoção das moléculas de DNA aderidas à membrana dos 
espermatozóides, sendo possível, deste modo, estimar o número de moléculas de DNA interiorizadas nas células espermáticas.

A incubação de células espermáticas bovinas com moléculas exógenas do vetor pCX-EGFP captaram na membrana plasmática uma média de 500 mil cópias para cada 200 ng de DNA total extraído. Sobre as mesmas condições foram interiorizadas cerca de 100 mil cópias, representando $20 \%$ do número de cópias que foi retida na membrana plasmática. Estes resultados estão de acordo com os valores de recombinação encontrados por Kang et al. (2008), no qual espermatozóides suínos apresentaram uma variação individual de interiorização de $8,5 \%$ a $31,5 \%$ das moléculas exógenas de DNA. Neste trabalho, a opção de se trabalhar com uma mistura homogênea de sêmen de diferentes touros (pool) foi adotada para remover esta variação individual. $O$ valor médio de interiorização referida no trabalho de Kang et al. (2008), surpreendentemente, resulta em taxa idêntica de $20 \%$ de interiorização, corroborando com os dados deste estudo. Em contra partida, Ma et al. (2009) realizaram estudo com extrato nuclear de espermatozóides de carneiro, no qual, notaram que apenas 0,0004 \% (78/186.000) cópias de DNA foram incorporadas ao núcleo das células. Estas diferenças entre resultados pode ser explicada pelas distintas metodologias, já que extratos nucleares representam uma fração de todo o DNA que pode ter sido interiorizado na célula espermática. 


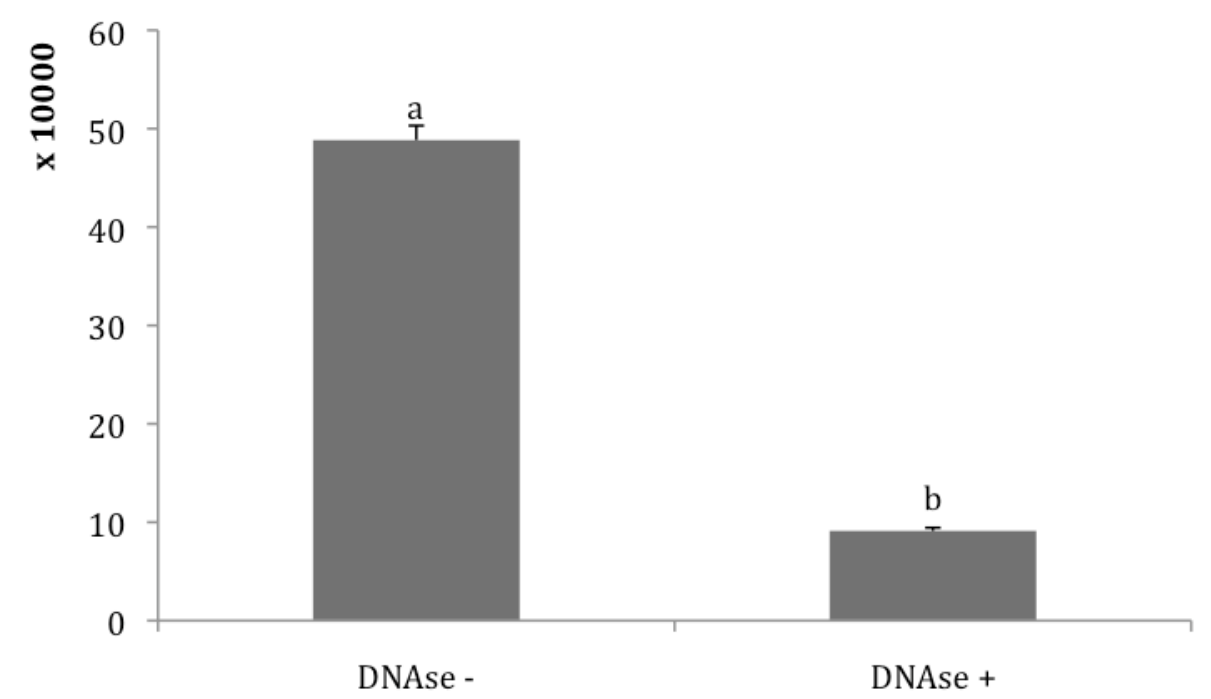

Figura 9 Efeito da adição de DNAse I sobre o número de cópias amplificadas por qPCR para cada $200 \mathrm{ng}$ de DNA total extraídos de espermatozóides. DNAse - = espermatozóides incubados com o vetor recombinante pCX-EFP; DNAse + = espermatozóides após tratamento com DNAse I.a,b: Letras diferentes indicam diferença significativa entre colunas $(p>0,05)$.

Os dados aqui apresentados revelam que não houve efeito significativo dose dependente com relação a quantidade de DNA utilizada para incubar os espermatozóides e o número de cópias interiorizadas ou aderidas à membrana plasmática dos espermatozóides. A Figura 10 mostra o valor médio do número de cópias captadas pelos espermatozóides, tanto na membrana plasmática quanto às interiorizadas na célula, agrupados nas distintas concentrações de DNA. Os valores numéricos apresentam um crescimento progressivo que acompanha o aumento da concentração de DNA exógeno. No entanto, não foi possível notar um efeito dose dependente como o relatado por Feitosa et al. (2010). Esta discordância entre resultados pode ser explicada pelas diferentes metodologias. Feitosa et al. (2010) utilizaram diferentes concentrações de DNA (100, 500 e 1000 ng de DNA) e com tempo de incubação dos espermatozóides com 60 e 120 minutos de incubação, sendo que no presente trabalho foi empregado concentração de 250, 500 e 1000ng e tempo de incubação de 30 minutos. Deste modo, a relação tempo de incubação $X$ quantidade de DNA parece ser importante para notar o efeito dose dependente na captação de moléculas exógenas de DNA por espermatozóide bovinos. Canovas et al. (2010) demonstraram que espermatozóides bovinos captam rapidamente as moléculas de DNA nos primeiros 
5 minutos de incubação, apresentando um aumento progressivo de captação até 10 minutos de incubação e após este período atingem um platô no que se refere à captação de DNA exógeno.

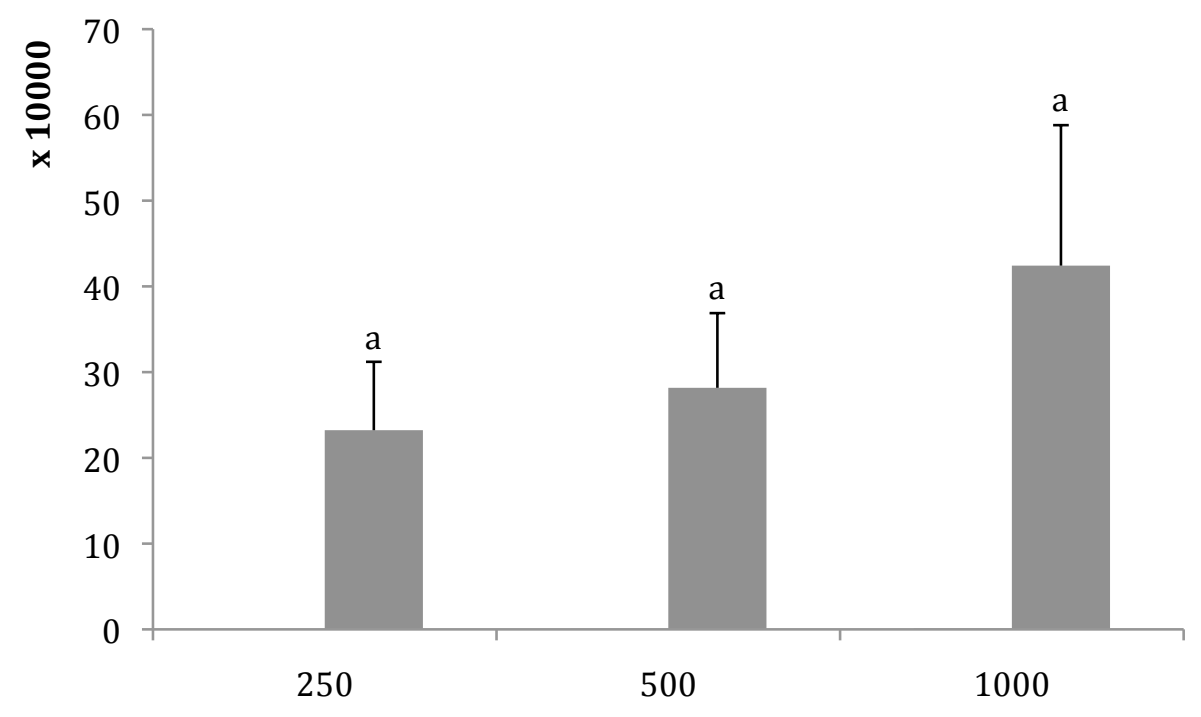

Figura 10 Efeito da adição de diferentes concentrações de DNA (250, 500 e 1000ng) sobre o número de cópias amplificadas em tempo real para cada 200 ng de DNA total, extraídos de espermatozóides. a,b: Letras diferentes indicam diferença significativa entre colunas $(p>0,05)$.

O uso da eletroporação das células espermáticas incubadas com o vetor recombinante não causou alteração significativa no número de cópias amplificadas em tempo real para cada 200 ng de DNA total extraído (Figura 11). Numericamente foi possível observar diminuição do número de cópias amplificadas no grupo de espermatozóides eletroporados, sem no entanto apresentar diferença para um nível de significância de 5\%. 


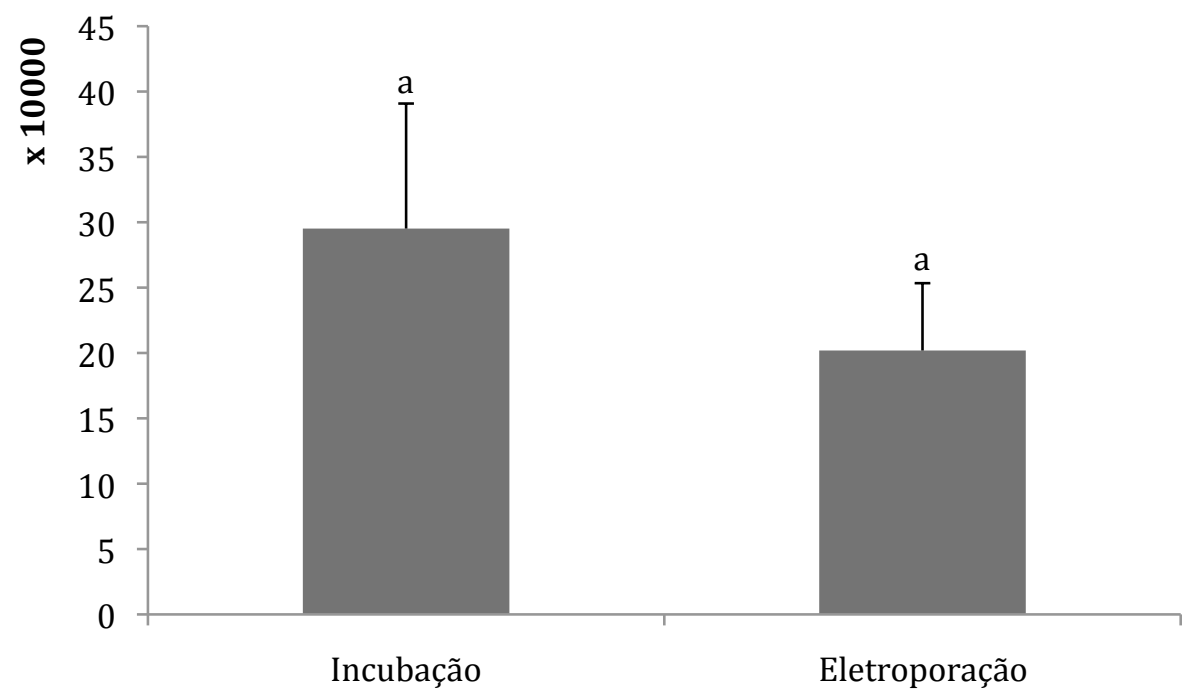

Figura 11 Efeito dos distintos métodos de transfecção (incubação e eletroporação) sobre o número de cópias amplificadas em tempo real, para cada 200 ng de DNA total extraídos de espermatozóides. a,b: Letras diferentes indicam diferença significativa entre colunas $(p>0,05)$.

\subsubsection{Efeito de protocolos de TGME em organelas espermáticas}

Os resultados dos efeitos da adição de moléculas exógenas de DNA ou uso de diferentes métodos de transfecção espermática sobre as membranas plasmática e acrossomal, o potencial de membrana mitocondrial e a fragmentação de DNA estão apresentados e discutidos a seguir.

\subsubsection{Avaliação de membrana plasmática e acrossomal}

Os resultados da citometria de fluxo para avaliação da integridade de membrana citoplasmática e acrossomal estão descritos na Figura 12. Não houve interação entre os fatores avaliados no presente experimento sobre as distintas populações celulares (Tabela 2). Assim, os dados foram analisados levando-se em conta cada um dos fatores separadamente, sendo apresentado na Figura 12 os 
dados em relação a quantidade de DNA utilizado (0, 250, 500 e 1000 ng), e na Figura 13 em relação aos métodos de transfecção (incubação e eletroporação).

Tabela 2 Efeito da concentração de DNA (0, 250, 500, $1000 \mathrm{ng})$, do método de transfecção (incubação, eletroporação) e da interação DNA x método de transfecção sobre a porcentagem de células íntegras (INT); com lesão de membrana plasmática (LMP); com lesão de membrana acrossomal (LMA); com lesão em ambas membranas (LMP/LMA).

\begin{tabular}{lccc}
\hline & DNA & $\begin{array}{c}\text { Método de } \\
\text { Transfecção }\end{array}$ & $\begin{array}{c}\text { DNA x método de } \\
\text { transfecção }\end{array}$ \\
\hline INT & 0,2386 & 0,8102 & 0,3275 \\
LMP & 0,0857 & 0,7050 & 0,3495 \\
LMA & 0,0469 & 0,1875 & 0,4170 \\
LMP/LMA & 0,1028 & 0,1056 & 0,4948 \\
\hline
\end{tabular}

$a, b$ : Letras diferentes indicam diferença significativa entre colunas $(p>0,05)$.

Não houve efeito da adição de DNA na percentagem de espermatozóides íntegros (INT), com lesão de membrana plasmática (LMP) ou com lesão em ambas as membranas (LMP/LMA). No entanto, a adição de DNA exógeno alterou a membrana acrossomal dos espermatozóides, entre o grupo controle e o grupo com $500 \mathrm{ng}$ de DNA. Provavelmente uma alteração pontual, visto que em doses maiores ou menores de DNA estas diferenças não mantiveram proporcionalidade (Figura 12). Estudando os efeitos da TGME na viabilidade espermática Bacci el al. (2009) observaram que nos primeiros passos de manipulação dos espermatozóides ocorre um pequeno aumento de lesão de acrossomo nas células espermáticas. Um aumento significativo no dano acrossomal foi identificado em espermatozóides incubados com $100 \mu \mathrm{g}$ de DNA após 48 horas de incubação, quando comparado ao grupo controle (BACCl et al., 2009). Deste modo, os danos acrossomais em protocolos de TGME não apresentam um efeito aparente ou tendência. 


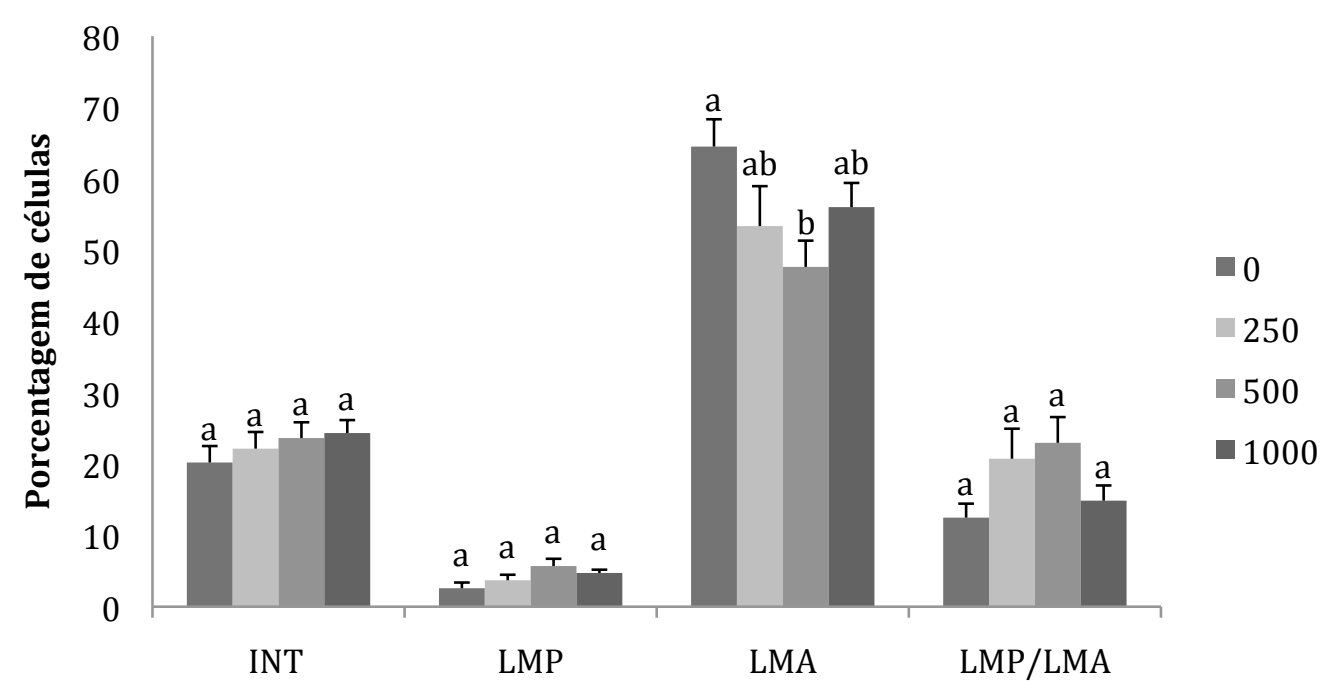

Figura 12 Efeito da adição de diferentes concentrações de DNA sobre as variáveis espermatozóides íntegros (INT), com lesão de membrana plasmática (LMP), com lesão de membrana acrosomal (LMA) e com lesões em ambas as membranas (LMP/LMA). Letras minúsculas $(a, b)$ indicam diferença significativa entre as médias dentro da mesma variável $(\mathrm{p}<0,05)$.

A utilização da eletroporação em condições de $300 \mathrm{~V}, 35 \mu \mathrm{F}$ e $0,25 \mathrm{mseg}$ não afetou as membranas plasmática e acrossomal de espermatozóides bovinos, não alterando também a percentagem de células íntegras (Figura 13). Estes resultados estão em concordância aos apresentados por Gagne et al. (1991) utilizando metodologia de coloração de acrossomo com amarelo naftol $\mathrm{S}$ e eritrosina $B$ em microscopia de contraste de fase, no qual demonstraram que não houve aumento no número de espermatozóides bovinos com reação acrossomal quando eletroporados com ou sem DNA exógeno. 


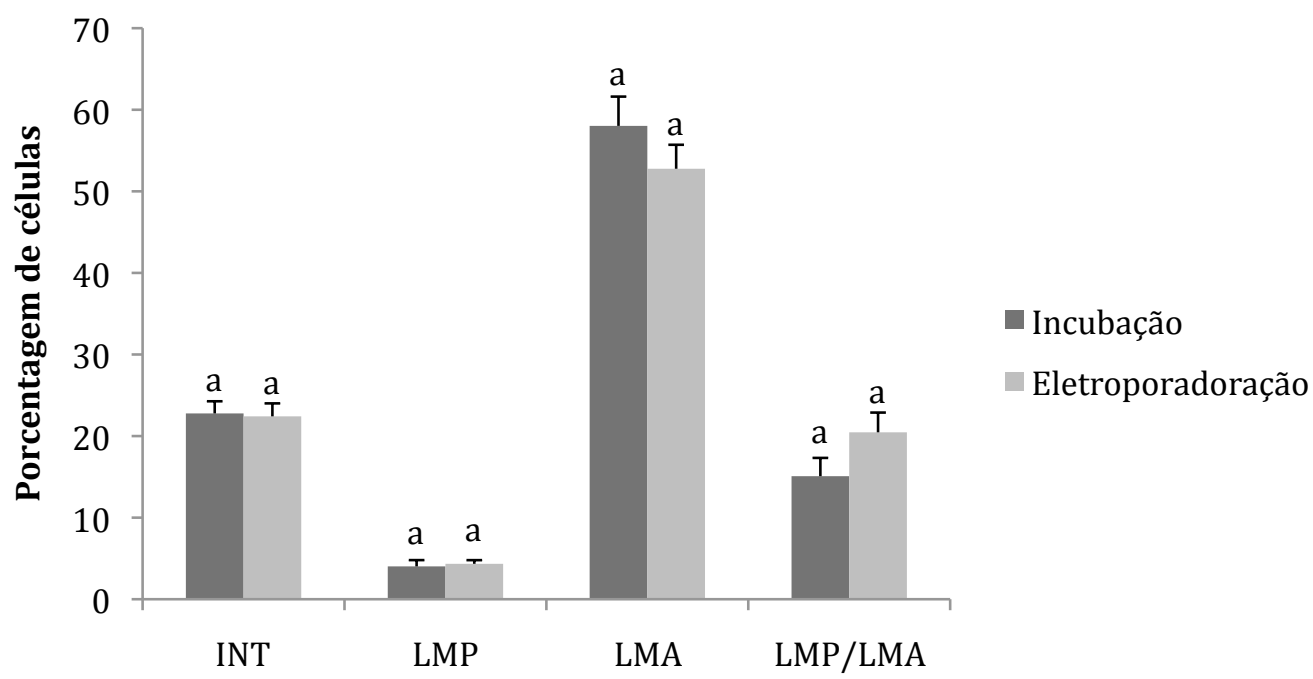

Figura 13 Efeito da aplicação de disitntos métodos de transfecção sobre as variáveis íntegros (INT), lesão de membrana plasmática (LMP), lesão na membrana acrosomal (LMA) e lesões em ambas as membranas (LMP/LMA), nos distintos métodos de transfecção (incubação ou eletroporação). Letras minúsculas $(a, b)$ indicam diferença significativa entre as médias dentro da mesma variável $(p<0,05)$.

\subsubsection{Avaliação de potencial de membrana mitocondrial}

Com relação ao potencial de membrana mitocondrial foi encontrada uma interação entre a adição de moléculas exógenas de DNA e a aplicação dos distintos métodos de transfecção para células com alto potencial de membrana mitocondrial (Tabela 3). No caso das células apresentando baixo potencial de membrana mitocondrial foi observada uma tendência à interação. Neste caso, pela proximidade à significância $(0,0539)$, optou-se por analisar os dados considerando a interação entre DNA e métodos de transfecção.

Tabela 3 Efeito da concentração de DNA $(0,250,500,1000 \mathrm{ng})$, do método de transfecção (incubação, eletroporação) e da interação DNA $x$ método de transfecção sobre a porcentagem de espermatozóides com alto potencial de membrana mitocondrial (APMM) e baixo potencial de membrana mitocondrial (BPMM).

\begin{tabular}{lccc}
\hline & DNA & $\begin{array}{c}\text { método de } \\
\text { transfecção }\end{array}$ & $\begin{array}{c}\text { DNA x método de } \\
\text { transfecção }\end{array}$ \\
\hline APMM & 0,5865 & $<0,0001$ & 0,0436 \\
BPMM & 0,6560 & $<0,0001$ & 0,0539 \\
\hline
\end{tabular}


A porcentagem de células com alto potencial de membrana mitocondrial (APMM) não diferiu em relação às diferentes concentrações de DNA quando apenas incubadas com DNA exógeno (Tabela 4). No entanto, quando eletroporadas houve menor porcentagem de células com alto potencial de membrana mitocondrial nas células controle (sem adição de DNA) quando comparadas às tratadas com 250 ng de DNA $(46,16 \pm 3,89$ vs 55,67 $\pm 3,70$, respectivamente). A eletroporação gera uma diminuição na porcentegem de células com APMM em todas as concentrações de DNA com exceção na concentração de 250 ng. Estes resultados sugerem que a eletroporação afeta as funções mitocondriais dos espermatozóides.

Os mecanismos de captação e interiorização aparentemente não causam alteração na função mitocondrial, pois nas distintas concentrações de DNA não houve grandes alterações da função mitocondrial. A avaliação da função mitocondrial realizada por Bacci et al. (2009) revelou que a adição de DNA em espermatozóides suínos não causou alteração no potencial de membrana mitocondrial em espermatozóides incubados com DNA. Deste modo, todos os indícios de disfunção mitocondrial apontam para a aplicação de pulso elétrico sobre as células espermáticas (eletroporação).

Tabela 4 Porcentagem de células com alto potencial de membrana mitocondrial (APMM) nos diferentes tratamentos.

\begin{tabular}{lcccc}
\hline & 0 & 250 & 500 & 1000 \\
\hline Incubação & $67,40 \pm 1,95^{\mathrm{a} ; \mathrm{A}}$ & $62,79 \pm 2,18^{\mathrm{a} ; \mathrm{A}}$ & $66,56 \pm 1,17^{\mathrm{a} ; \mathrm{A}}$ & $67,03 \pm 0,69^{\mathrm{a} ; \mathrm{A}}$ \\
Eletroporação & $46,16 \pm 3,89^{\mathrm{b} ; \mathrm{A}}$ & $55,67 \pm 3,70^{\mathrm{a} ; \mathrm{B}}$ & $50,81 \pm 1,78^{\mathrm{b} ; \mathrm{AB}}$ & $52,24 \pm 0,87^{\mathrm{b} ; \mathrm{AB}}$ \\
\hline $\begin{array}{l}\text { ab: letras minúsculas diferentes indicam diferenças significativas entre colunas ( } \mathrm{p}<0,05) . \\
\text { AB: letras maiúsculas diferentes indicam diferença significativas entre linhas ( } \mathrm{p}<0,05) .\end{array}$
\end{tabular}

A hipótese de efeito deletério à função mitocondrial causada pela eletroporação é mais evidente quando observada a população de células com baixo potencial de membrana mitocondrial. Ao observar a Tabela 5 , nota-se que a população de células espermáticas com baixo potencial de membrana mitocondrial foi influenciada pela eletroporação ( $p>0,05)$. Os resultados aqui apresentados evidenciam que a eletroporação aumenta a população de espermatozóides com 
baixo potencial de membrana mitocondrial, e diminui a população de células espermáticas com alto potencial de membrana mitocondrial (Tabela 5).

Tabela 5 Percentagem de células com baixo potencial de membrana mitocondrial (BPMM) nos diferentes tratamentos.

\begin{tabular}{lcccc}
\hline & $\mathbf{0}$ & $\mathbf{2 5 0}$ & $\mathbf{5 0 0}$ & 1000 \\
\hline Incubação & $18,24 \pm 2,51^{\mathrm{a} ; \mathrm{A}}$ & $22,37 \pm 1,91^{\mathrm{a} ; \mathrm{A}}$ & $21,20 \pm 0,43^{\mathrm{a} ; \mathrm{A}}$ & $20,29 \pm 0,67^{\mathrm{a} ; \mathrm{A}}$ \\
Eletroporação & $43,89 \pm 4,24^{\mathrm{b} ; \mathrm{A}}$ & $34,45 \pm 3,17^{\mathrm{b} ; \mathrm{A}}$ & $37,80 \pm 1,69^{\mathrm{b} ; \mathrm{A}}$ & $37,51 \pm 1,95^{\mathrm{b} ; \mathrm{A}}$ \\
\hline $\begin{array}{l}\text { ab: letras minúsculas diferentes indicam diferenças significativas entre colunas }(\mathrm{p}<0,05) . \\
\text { AB: letras maiúsculas diferentes indicam diferença significativa entre linhas }(\mathrm{p}<0,05) .\end{array}$
\end{tabular}

\subsubsection{Avaliação da fragmentação de DNA em espermatozóides}

A análise do efeito da concentração de DNA exógeno e do método de transfecção (incubação e eletroporação), na susceptibilidade do DNA espermático à desnaturação ácida (fragmentação de DNA), não apresentou interação entre os variáveis (Tabela 6), sendo as mesmas analisadas separadamente.

Tabela 6 Efeito da concentração de DNA (0, 250, 500, $1000 \mathrm{ng})$, do método de transfecção (incubação, eletroporação) e da interação DNA x método de transfecção sobre a susceptibilidade do DNA espermático à desnaturação ácida (fragmentação de DNA).

\begin{tabular}{cccc}
\hline & DNA & $\begin{array}{c}\text { Método de } \\
\text { Transfecção }\end{array}$ & $\begin{array}{c}\text { DNA x método de } \\
\text { transfecção }\end{array}$ \\
\hline $\begin{array}{c}\text { Fragmentação de } \\
\text { DNA }\end{array}$ & 0,2098 & 0,0197 & 0,4485 \\
\hline
\end{tabular}

A adição de moléculas exógenas de DNA, mesmo em de diferentes concentrações não exerceu qualquer influência na porcentagem de fragmentação do DNA dos espermatozóides (Figura 14). 


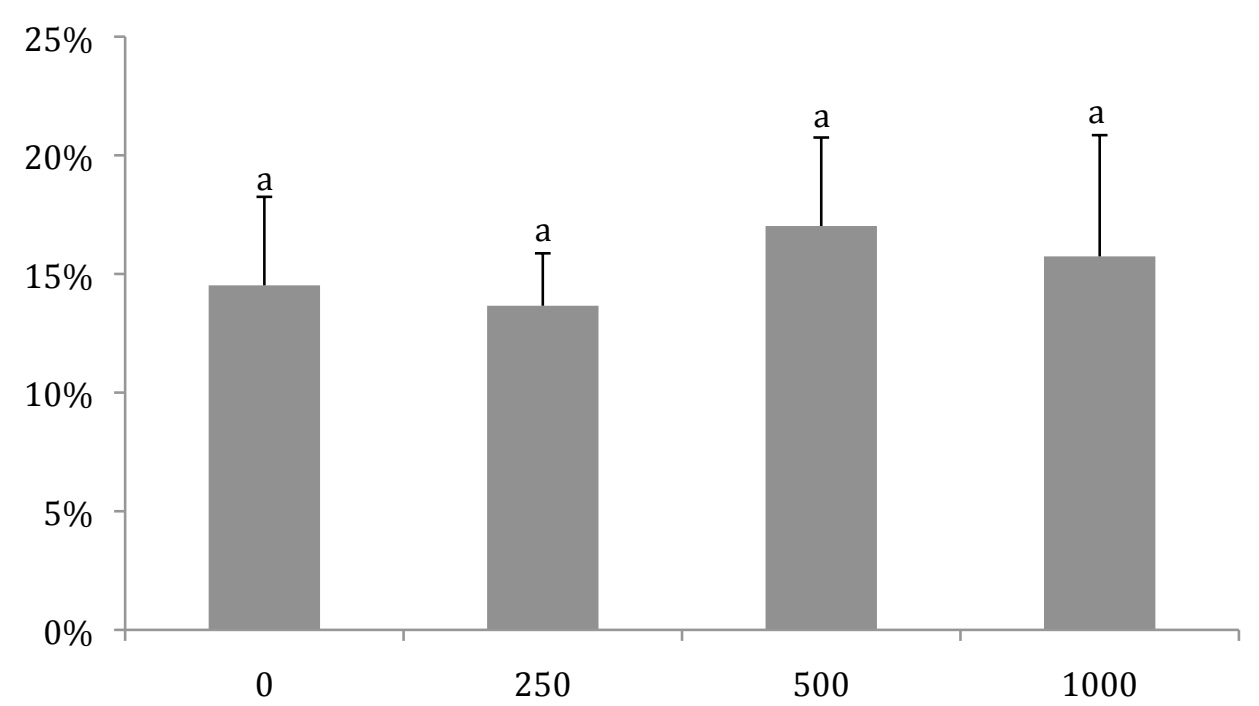

Figura 14 Efeito das diferentes concentrações de DNA exógeno $(0,250,500,1000)$ sobre a susceptibilidade do DNA espermático à desnaturação ácida (fragmentação de DNA). Letras minúsculas $(a, b)$ indicam diferença significativa entre as médias, dentro da mesma variável $(p<0,05)$.

Os tratamentos com uso da eletroporação apresentaram um aumento na fragmentação do DNA ( $p>0.05$ ). O valor médio das amostras incubadas com DNA não eletroporadas foi de $14,17 \%( \pm 0,68 \%)$, estando contidas na categoria de células com baixa fragmentação de DNA, pelo ensaio de SCSA, de acordo com Evenson e Jost (2000). O valor médio das amostras eletroporadas foi de 18,08\% ( \pm $1,35 \%$ pertencendo a categoria de células com intermediário índice de fragmentação de DNA (Figura 15). Esta metodologia de avaliação de estrutura de cromatina de DNA espermático, até o presente momento, nunca havia sido aplicada em espermatozóides tratados com DNAse I em protocolos de TGME. No estudo de Feitosa et al. (2010) não foram observadas alterações na fragmentação de DNA espermático no ensaio de SCSA em espermatozóides bovinos submetidos a protocolos de TGME utilizando a incubação como método de transfecção, sem no entanto haver tratamento com DNAse I. Devido a este fato, não há referências na literatura para embasar se o aumento do índice de fragmentação de DNA nas amostras eletroporadas, ocorreram porque houve dano na estrutura da cromatina causada pela DNAse I ou se a eletroporação por si só possa causar danos à cromatina espermática. 


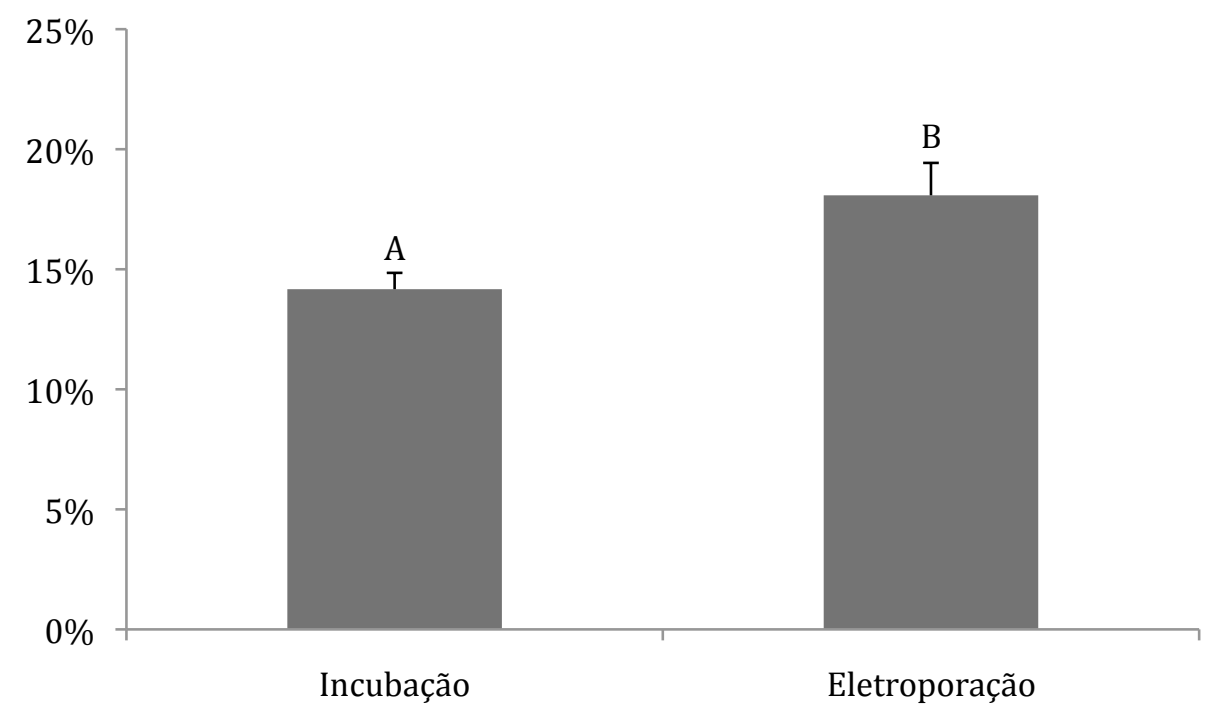

Figura 15 Efeito dos métodos de transfecção (incubação ou eletroporação) sobre a susceptibilidade do DNA espermático à desnaturação ácida (fragmentação de DNA). Letras minúsculas $(a, b)$ indicam diferença significativa entre as médias dentro da mesma variável $(p<0,05)$.

As evidências de que o uso da eletroporação altere o índice de fragmentação de DNA avaliado pelo método de Ensaio de Estrutura de Cromatina Espermático (SCSA), deve ser melhor investigado para não restar dúvidas quanto ao efeito do tratamento com DNAse I nos resultados obtidos.

6.1.3 Análise topográfica do inserto no genoma espermático

A Figura 16 mostra o resultado das hibridizações in situ em espermatozóides bovinos utilizando uma sonda telomérica como controle. Não foi observado sinal de fluorescência nestas amostras. A observação minuciosa da imagem evidencia que morfologicamente os núcleos apresentam formato piriforme, que acompanha a morfologia da cabeça espermática. Esta característica morfológica sugere que as células não sofreram desnaturação da estrutura de cromatina espermática, dificultando o acesso das sondas ao sítio de reconhecimento, podendo ser eliminadas quando da confecção das lâminas, durante as etapas de lavagem sucessivas. 
Utilizou-se, para este estudo, o protocolo de desnaturação da estrutura de cromatina espermática descrito por Rens et al. (2001), baseado em termo desnaturação. O padrão morfológico de lesão espermática descrito por Rens et al. (2001) para caracterizar a desnaturação da estrutura de cromatina espermática não pode ser observado na população de espermatozóides utilizadas no presente estudo. O fato de Rens et al. (2001) terem trabalhado com animais Bos taurus e o presente estudo com Bos indicus talvez explique as diferenças de padrões entre os dois experimentos.

Para compreender os fenômenos de veiculação do transgene durante os protocolos de TGME são necessários maiores esforços para buscar visualizar a integração do transgene no genoma espermático. Para isso faz-se necessário o ajuste das condições de desnaturação da cromatina espermática, para viabilizar a utilização da técnica de hibridização in situ.

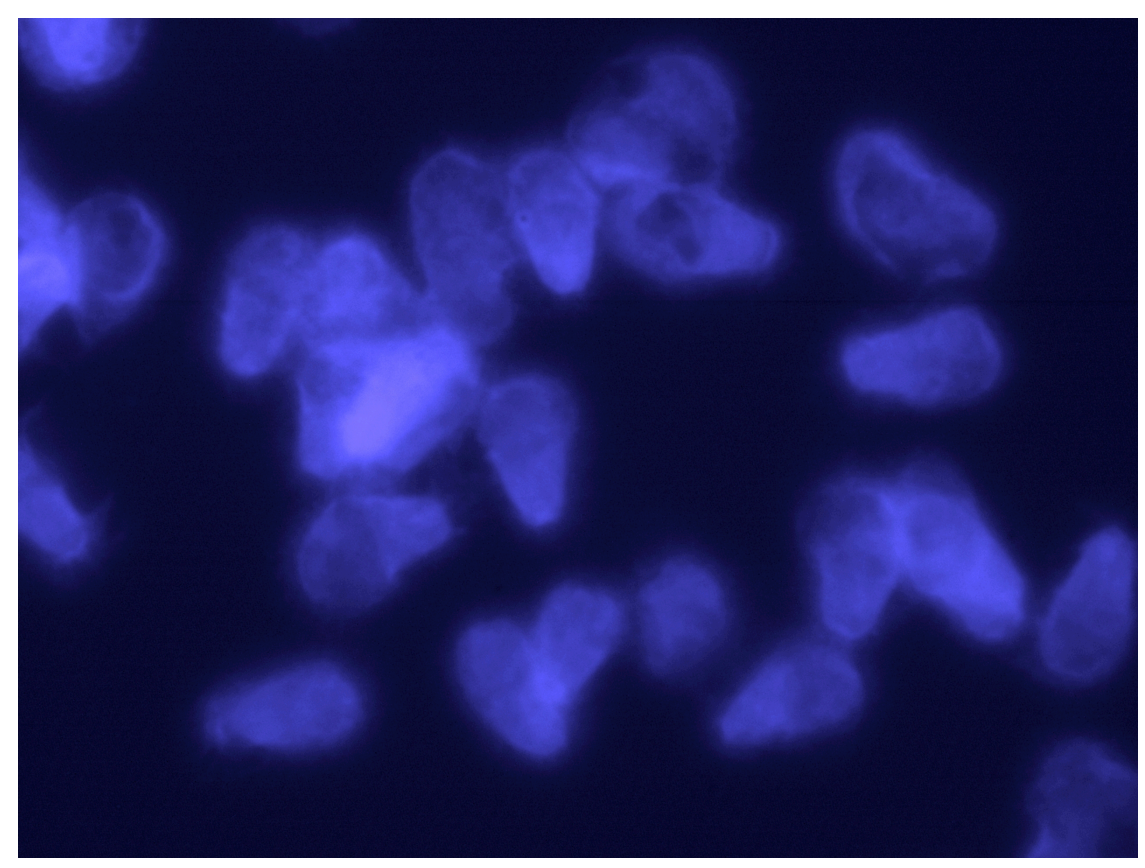

Figura 16 Fotografia da hibridização in situ controle das células espermáticas, com uso de sonda telomérica. Não foi observado sinal de fluorescência (Magnitude $200 \mathrm{x}$ ). 
6.1.4 Análise do perfil eletroforético das proteínas do plasma seminal

A quantificação das concentrações de proteínas totais das distintas fases do gradiente de Percoll revelou diminuição brusca na quantidade de proteínas entre a fase 1 e as demais fases do gradiente. Ocorre também uma diminuição na concentração protéica entre as fases 2 e 3 (Figura 17). O meio (TALP), no qual o sedimento celular foi diluído (1:8) e centrifugado para a remoção das partículas residuais de Percoll apresentou um pequeno aumento na concentração protéica.

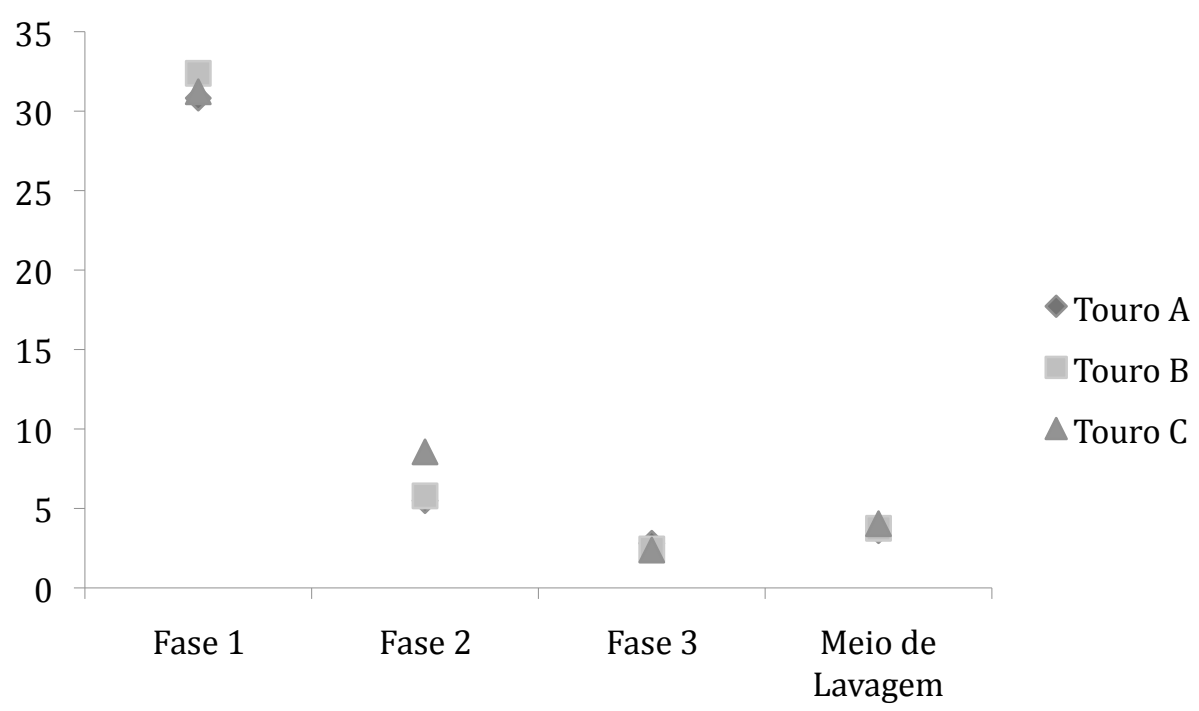

Figura 17 Concentração protéica em $\mathrm{mg} / \mathrm{ml}$ das distintas fases do gradiente de Percoll. Fase 1 , representa o conteúdo da fase superior. Fase 2, corresponde ao conteúdo da fase intermediária do gradiente. Fase 3, fase inferior do gradiente. Meio de lavagem, meio TALP onde $50 \mu \mathrm{l}$ do sedimento celular foi diluído (1:8) e centrifugado para remover partículas de Percoll residuais. Meio TALP apresenta $3,6 \mathrm{mg} / \mathrm{ml}$ de proteínas totais. A linha representa a tendência das amostras.

Gradientes de densidade apresentam a função de remover o meio de congelação e selecionar espermatozóides com maior motilidade. Por este motivo uma diminuição progressiva na concentração protéica, nas distintas fases do gradiente de Percoll (45/90\%) era esperado. O pequeno aumento na concentração protéica encontrado entre a fase 3 e o meio de lavagem se justifica pelo maior número de partículas de Percoll na fase 3. Por ser a fase na qual havia maior volume de partículas de Percoll, a fase 3 apresentou menor quantidade de proteína por volume analisado. 
O perfil eletroforético das proteínas nas distintas fases do gradiente confirmaram a redução na concentração protéica (Figura 18). Foi possível notar a ausência de proteínas com massa molecular inferior a $55 \mathrm{KDa}$, sugerindo a remoção completa do IF-1 (37 KDa - colocar referência). Deste modo, os protocolos de TGME que utilizam o gradiente de Percoll (45/90\%) para a separação dos espermatozóides, não sofrem influência do fator inibitório 1.

Figura 18 Perfil eletroforético em SDS-PAGE das proteínas do gradiente de Percoll. 1, proteína referência de $55 \mathrm{KDa}$. 2, meio de congelação onde os espermatozóides foram congelados. 3, proteínas da Fase 1. 4, proteínas da Fase 2. 5, proteínas da Fase 3. 6, proteínas do meio no qual o sedimento celular foi diluído para a remoção das partículas residuais de Percoll.

\subsection{Experimento 2 - Estudo do potencial de produção e desenvolvimento de embriões in vitro com uso de espermatozóides tratados com DNA exógeno}

Para a produção in vitro de embriões foi utilizada a concentração de $1000 \mathrm{ng}$ DNA $/ 10^{6}$ células (experimento 1 ), sendo todas as amostras tratadas posteriormente com DNAse I. Foram comparados os métodos de transfecção (incubação e eletroporação) quanto à produção de embriões e índice de transfecção de DNA exógeno. 
6.2.1 Potencial de produção e desenvolvimento in vitro de embriões

Os índices aqui expostos (Tabela 7) são provenientes de quatro manipulações consecutivas com resultados homogêneos. Foram obtidos os índices de clivagem, blastocisto e eclosão dos grupos controle, incubado e eletroporado.

Não houve diferença entres os índices nos diferentes tratamentos, sugerindo que a adição de moléculas de DNA ou o uso da eletroporação não influenciaram no potencial de fecundação dos espermatozóides e subseqüente desenvolvimento embrionário.

Tabela 7 Efeito dos métodos de transfecção (controle, incubação, eletroporação) nos índices de Clivagem, Blastocisto e Eclosão dos embriões bovinos produzidos in vitro com uso dos espermatozóides tratados com 1000 ng de DNA exógeno.

Tratamento

\begin{tabular}{lcccc}
\cline { 2 - 4 } Índice (\%) & Controle & Incubação & Eletroporação & p \\
\hline Clivagem & $51,60 \pm 4,1$ & $49,83 \pm 2,7$ & $52,53 \pm 1,0$ & 0,8099 \\
Blastocisto & $24,36 \pm 8,6$ & $19,65 \pm 2,5$ & $17,40 \pm 4,6$ & 0,7014 \\
Eclosão & $13,02 \pm 4,6$ & $10,54 \pm 1,2$ & $8,35 \pm 3,4$ & 0,6422 \\
\hline
\end{tabular}

Os resultados aqui apresentados estão de acordo com os resultados encontrados por Canovas et al. (2010), no qual espermatozóides bovinos tratados com DNA exógeno não diferiram do grupo controle. Obtiveram índice de clivagem de $78,14 \%$ para espermatozóides tratados com DNA e $81,43 \%$ para o grupo controle. As conclusões relatadas por Bacci et al. (2009) evidenciam que espermatozóides suínos tratados com DNA exógeno não apresentaram alteração in vitro do desempenho fecundante, o que corrobora com os resultados deste experimento, o que leva a crer que, independente da espécie, o tratamento com DNA não diminui a função espermática.

A eletroporação pareceu não exercer impacto no potencial de fecundação de espermatozóides bovinos. Rieth et al. (2000) observaram que a eletroporação não exerce efeito significativo no desenvolvimento embrionário, porém, notaram 
redução nos índices de fecundação dos oócitos, quando usada a eletroporação combinada à adição de moléculas de DNA. Este fenômeno não foi observado nos resultados aqui apresentados.

Enzimas de reparação de DNA apresentam alta atividade em oócitos, criando um eficiente mecanismo de reparação do DNA espermático (ASHWOODSMITH; EDWARDS, 1996). Particularmente, o oócito apresenta a capacidade de reparar completamente danos quando estes ocorrem em uma das fitas do DNA espermático. No entanto, se um grande dano ocorre em ambas as fitas do DNA, o oócito ao tentar repará-las pode cometer erros gerando mutações que podem bloquear ou alterar o desenvolvimento embrionário (BRAUDE et al., 1998). Este mecanismo reparativo oocitário pode exercer influência na TGME, corrigindo possíveis danos da cromatina espermática o que culmina na manutenção dos índices de produção in vitro de embriões. Mesmo com o uso de espermatozóides com intermediário índice de fragmentação de DNA (espermatozóides eletroporados) as taxas de clivagem, blastocisto e eclosão não apresentaram diferença significativa. Provavelmente devido a esta capacidade reparadora do oócito e por que os índices de fragmentação apresentados não eram tão intensos (classificados como intermediário), o que indiretamente valida os resultados deste teste observados no experimento 1.

6.2.2 Avaliação da expressão do gene marcador em embriões produzidos in vitro

A observação das estruturas embrionárias sob a excitação da luz ultravioleta com filtro de 480 - 507 nanômetros, revelou a presença de embriões com expressão mosaica do gene da GFP. A Figura 19 exemplifica os padrões de fluorescência encontrados nos embriões. 


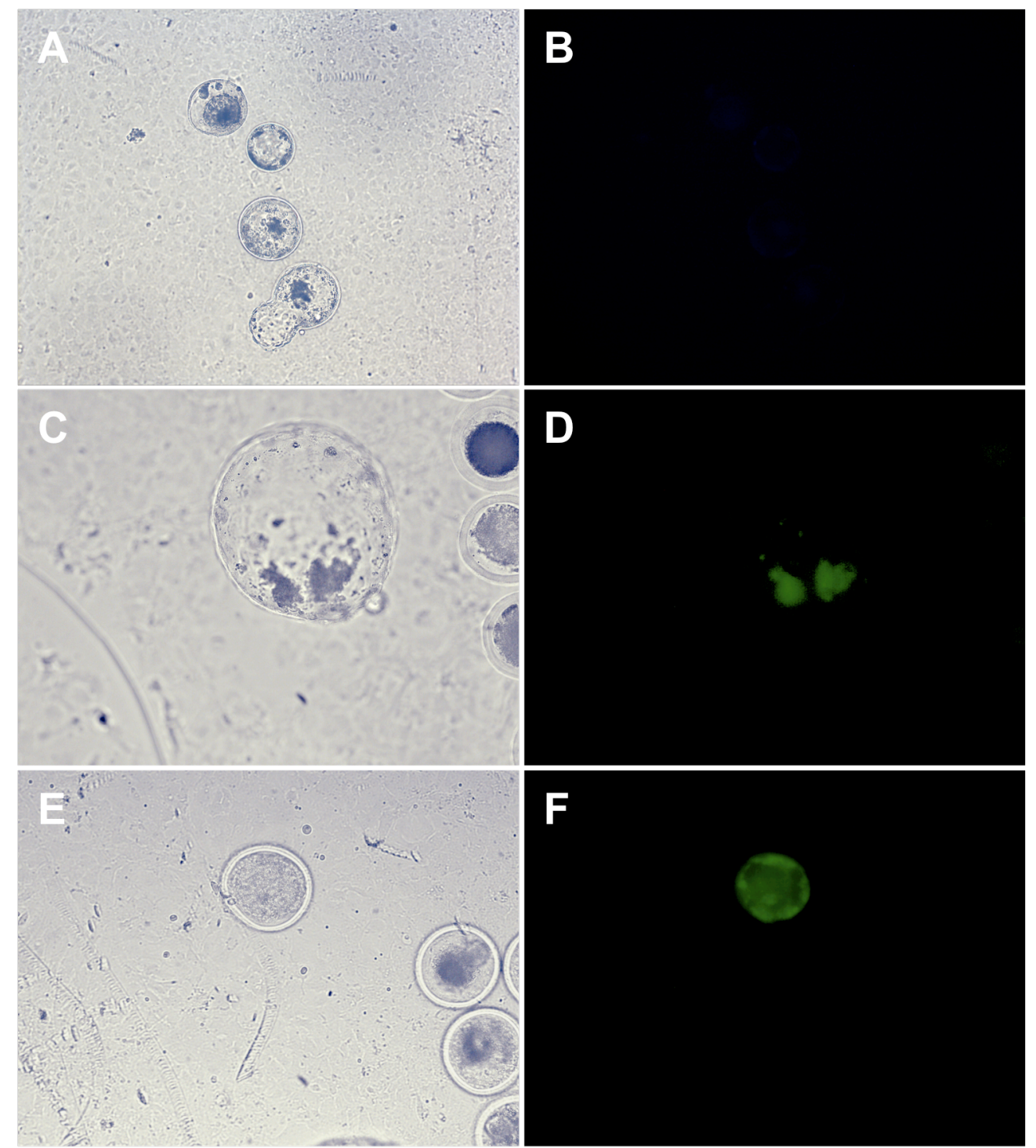

Figura 19 Fotografias dos embriões produzidos in vitro após protocolo de TGME. Em "A" embriões do grupo controle, em "B" os mesmos embriões sobre a excitação da luz ultravioleta e filtro de 480 - $507 \mathrm{~nm}$ (magnitude de $100 \mathrm{x}$ ). Em "C e D" blastocisto expandido do grupo incubação. Em "E e F" blastocisto inicial do grupo eletroporação (magnitude de $200 \mathrm{x}$ ).

A expressão do gene da GFP pode ser observada em 0,039 \% (5/127) dos embriões do grupo incubado e em 0,015 \% (2/131) dos embriões do grupo eletroporado. Estes resultados se contrapõem aos encontrados por Rieth et al. (2000), nos quais não houve a expressão do gene da GFP nos embriões produzidos in vitro. Estes autores justificam este fato devido a falta da sequência CMV no vetor $\beta$ actin GFP que utilizaram. Quando os embriões foram avaliados por PCR puderam observar elevada taxa de recombinação (55\% dos embriões eletroporados positivos). No entanto, a ausência da sequência promotora CMV parece não ser a justificativa para a não expressão do gene marcador GFP. No 
estudo de Canovas et al. (2010) foi utilizada uma construção gênica (pEGFPN1), que apresentava a sequência CMV e mesmo assim os embriões gerados pela FIV não apresentaram sinal de fluorescência. No presente trabalho, utilizou-se uma construção gênica que apresentava as duas sequências promotoras, a sequência CMV e a sequência $\beta$ actin, conjugadas. Pode ser observado que embriões com alta fluorescência (Figura 19 F) apresentavam características morfológicas alteradas, tais como sinais de fragmentação e citoplasma retraído (Figura $19 \mathrm{E}$ ), e embriões com baixa fluorescência (Figura 19 D) apresentaram características morfológicas normais (Figura $19 \mathrm{C}$ ). Esta observação sugere que o nível de expressão do transgene pode ter influência na qualidade embrionária, ou seja, em embriões nos quais há integração de muitas moléculas de DNA a viabilidade embrionária parece ser prejudicada.

Existe grande divergência de resultados de expressão do gene utilizado em trabalhos de TGME. Hoelker et al. (2007) analisando a expressão da GFP em embriões bovinos, obteve taxa de expressão de 3,6 \%. Na literatura disponível há descrição de taxas de expressão de 9,1 \% (PEREYRA-BONNET et al., 2008) a até $30 \%$ (SHEMESH et al., 2000).

6.2.3 Análise da presença do gene marcador em embriões produzidos in vitro

A detecção da presença do gene da GFP nos embriões foi realizada pela técnica de Polimerase Chain Reaction. Para isso, os embriões sofreram remoção mecânica (dissecação) da zona pelúcida e consequentemente a remoção de possíveis espermatozóides aderidos a esta.

A Figura 20 exemplifica a análise eletroforética do produto amplificado de embriões do grupo incubado. 


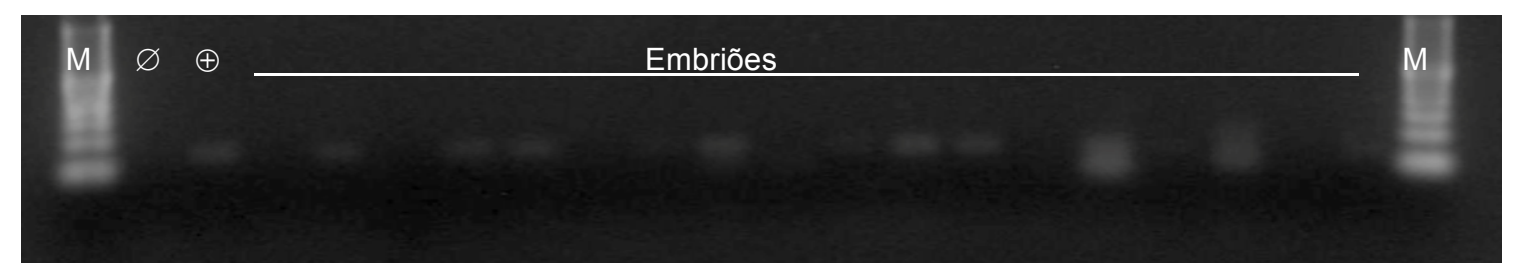

Figura 20 Análise eletroforética em gel de agarose a 3\% do produto de 67 pb amplificado da região codificadora da EGFP de embriões produzidos in vitro. M, Marcador de massa molecular de 50 pb. $\varnothing$, Controle negativo da reação. $\oplus$, Controle positivo da reação.

Foram detectados 12 embriões positivos de 69 embriões analisados para 0 grupo incubação, representando uma taxa de $0,17 \%$ de transgenia. Para o grupo eletroporação foram detectados 5 embriões positivos de 44 analisados, resultando em taxa de $0,11 \%$ (Tabela 8 ).

Tabela 8 Porcentagem de embriões positivos para fluorescência compatível com GFP e porcentagem de embriões positivos para a PCR, por método de transfecção (incubação e eletroporação).

\begin{tabular}{ccc}
\hline Tratamento & Fluorescência & PCR \\
\hline Incubação & $0,039 \%(5 / 127)$ & $0,17 \%(12 / 69)$ \\
Eletroporação & $0,015 \%(2 / 131)$ & $0,11 \%(5 / 44)$ \\
\hline
\end{tabular}

A expressão do transgene em embriões gerados por TGME parece ser um fenômeno menos freqüente do que os eventos de integração. Hoelker et al. (2007) reportaram uma taxa de expressão de 4,9\% de embriões expressando o transgene e uma taxa superior de $4,9 \%$ de embriões PCR positivos para o transgene. Os resultados apresentados neste presente trabalho são inferiores aos descritos na literatura para embriões bovinos (2 - 20\%) após protocolos de TGME (GANGE et al., 1991; PEREZ et al., 1991; ROTMANN et al., 1992; SPERANDIO et al., 1996; HOELKER et al., 2007). A TGME parece ser uma técnica com baixa repetibilidade, que sofre a influência de diversos fatores laboratoriais em seus resultados. 
6.2.4 Análise topográfica do inserto em embriões produzidos in vitro

As hibridizações in situ em embriões bovinos produzidos in vitro revelaram a presença do gene exógeno no genoma hospedeiro. Sinais de marcação do gene exógeno pode ser observado em pontos específicos do genoma. A sonda telomérica controle pode ser observada de forma difusa no genoma (Figura 21 A14), o que corresponde às sequências teloméricas características.
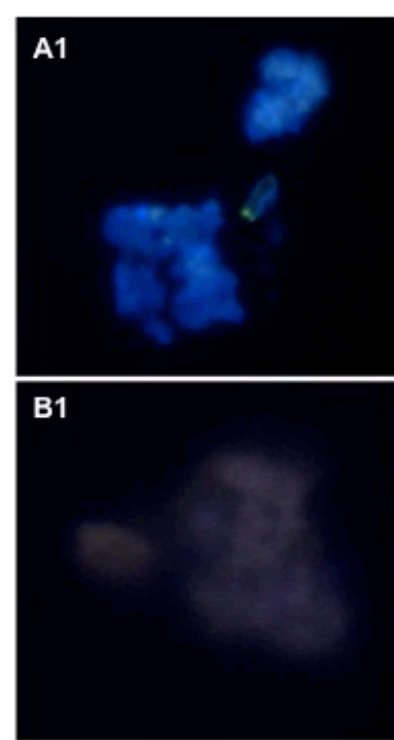

C1

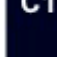

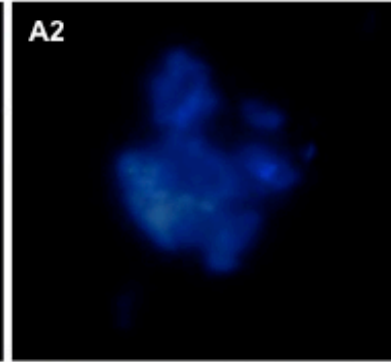

B2

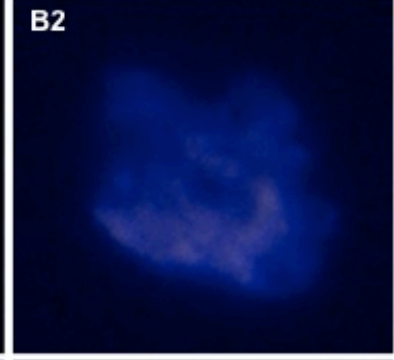

C2

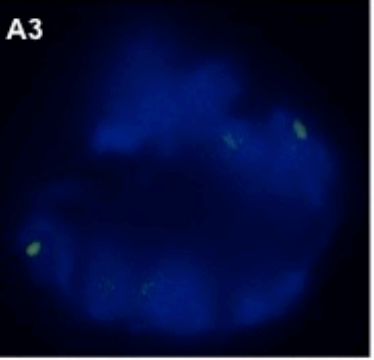

B3

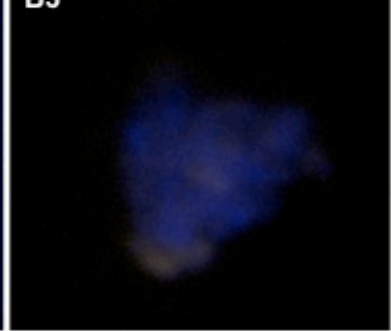

C3

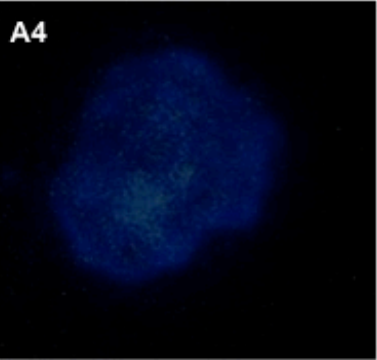

B4

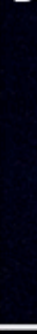

C4

Figura 21 Micrografias das hibridizações in situ em embriões. Em A1-4 embriões controle com marcações de sonda telomérica (verde). Em B1-4 embriões do grupo eletroporado apresentando sinal de marcação para o vetor pCX-EGFP (tons de vermelho). Em C1-4 embriões do grupo incubado e sinais de marcação da sonda pCX-EGFP (tons de vermelho)

A marcação para o transgene (pCX-EGFP) pode ser observada de forma focal em embriões do grupo o qual os espermatozóides foram incubados com DNA (Figura 21 C1-4), confirmando a provável expressão mosaica do transgene. No 
grupo o qual os espermatozóides foram eletroporados ocorreu uma marcação mais ampla e difusa (Figura 21 B1-4), sugerindo que um maior número de blastômeros apresentam o transgene. Um maior ou menor número de blastômeros com a presença do transgene possui relação direta com a fase do desenvolvimento embrionário no qual ocorre a recombinação do inserto (ANDREEVA et al., 2003). Quando o evento de recombinação ocorre em fases iniciais do desenvolvimento embrionário (2, 4 ou 6 células), maior número de células e tecidos do feto apresentam a expressão do transgene, contudo quando a recombinação ocorre em fases mais avançadas do desenvolvimento, um menor número de células e tecidos expressam o transgene. Os resultados de hibridização aqui apresentados, sustentam a observação de haver maior expressão do transgene nos embriões produzidos com espermatozóides eletroporados, sugerindo que com este protocolo ocorra eventos de recombinação nas etapas iniciais do desenvolvimento embrionário. 


\section{CONSIDERAÇÕES FINAIS}

Espermatozóides bovinos apresentam a capacidade de captar e interiorizar moléculas exógenas de DNA. Os resultados das quantificações em tempo real mostraram que aproximadamente $20 \%$ do total de moléculas exógenas de DNA aderidas aos espermatozóides foram interiorizadas. O perfil eletroforético das proteínas do gradiente de Percoll sugerem a ausência do Fator Inibitório 1. Assim as células espermáticas nos protocolos aqui utilizados estavam aptas a interiorizar as moléculas exógenas de DNA.

O uso de diferentes concentrações de DNA (250, 500 e $1000 \mathrm{ng} / 10^{6}$ células) gera um aumento numérico no número de cópias amplificadas para cada $200 \mathrm{ng}$ de DNA total extraído de espermatozóides. No entanto, não causou um efeito dose dependente significativo, como era esperado, entre as distintas concentrações de DNA (estes resultados estão discutidos no item 6.1.1).

A aplicação de dois métodos diferentes de transfecção espermática não causou diferença significativa entre o número de cópias amplificadas da sequência codificadora do gene da GFP. Pode ser observado uma diminuição numérica no número de cópias amplificadas no grupo no qual espermatozóides foram eletroporados. Estes resultados se contrapõem ao esperado, visto que, a eletroporação é uma técnica para aumentar as taxas de incorporação das moléculas exógenas de DNA (GAGNE et al., 1991; RIETH et al., 2000). A observação dos resultados do índice de fragmentação de DNA nos espermatozóides eletroporados mostrou um aumento significativo na susceptibilidade a desnaturação ácida neste grupo. A união destas informações sugerem um efeito negativo da eletroporação sobre a estrutura de cromatina espermática, no entanto, as células foram incubadas com DNAse I para remoção das moléculas de DNA não interiorizadas aos espermatozóides. Não há referências sobre os efeitos da eletroporação sobre a estrutura de cromatina espermática. Deste modo, não foi possível avaliar se o efeito da eletroporação sobre a célula espermática ocorre por alterações na membrana, que possivelmente facilitou a 
interiorização do DNA exógeno, mas também da enzima DNAse I, que uma vez internalizada, atacou a estrutura de cromatina e procedeu a digestão das moléculas de vetor interiorizadas. As evidências de que o uso da eletroporação altere o índice de fragmentação de DNA avaliado pelo método de Ensaio de Estrutura de Cromatina Espermático (SCSA), deve ser melhor investigado para não restar dúvidas quanto à influência do uso do tratamento com DNAse I ou eletroporação sobre a susceptibilidade a desnaturação ácida da cromatina espermática.

Alto índice de fragmentação de DNA espermático vem sendo descrito em espermatozóides com disfunções mitocondriais (LIU et al., 2004; NICHI et al., 2006). Podemos notar que espermatozóides eletroporados apresentaram uma redução na porcentagem de células com alto potencial de mitocôndria. É possível fazer uma relação entre o índice de fragmentação de DNA e a diminuição do potencial de membrana mitocondrial. Em vista disso, o uso da eletroporação, os índices de fragmentação de DNA espermático observados e a redução do potencial de membrana mitocondrial encontrados neste presente trabalho, parece ter uma relação muito próxima. Biologicamente estes eventos estão muito ligados. A hipótese levantada para explicar esta relação é de que a eletroporação cause danos mitocondriais que resultam na liberação de espécies reativas de oxigênio, e estas em decorrência provocam lesão na estrutura de cromatina dos espermatozóides.

Surpreendentemente o uso de espermatozóides eletroporados, com intermediário índice de fragmentação de DNA e uma população maior de células com baixo potencial de membrana mitocondrial, não causou redução no potencial in vitro de fecundação. Oócitos apresentam um estoque de mRNAs para a síntese de enzimas reparativas que formam um eficiente mecanismo de reparação de DNA, seja do genoma paterno ou materno (MÉNÉZO et al., 2010). Aparentemente este mecanismo reparativo oocitário exerceu influência na TGME, corrigindo danos da cromatina espermática que culminou na manutenção dos índices de produção in vitro de embriões inalterados.

Espermatozóides tratados com DNA e submetidos a dois métodos de transfecção apresentaram potencial de fecundação e desenvolvimento in vitro 
inalterado. Sendo possível utilizar células espermáticas como vetores para conduzir moléculas exógenas de DNA e gerar animais geneticamente modificados. A sequência de DNA do vetor utilizado parece ter grande influência nos resultados de integração e expressão do transgene. Sciamanna et al. (2000) testaram diversas sequências e concentrações de DNA exógeno em espermatozóides e notaram a influência destes fatores nos resultados da TGME.

É importante ressaltar que a expressão do transgene parece ser um fenômeno menos freqüente do que os eventos de integração. Neste estudo, a taxa de integração foi de $0,17 \%$ dos embriões produzidos com espermatozóides incubados com DNA exógenos. E uma taxa de 0,039 \% de embriões expressando o gene marcador da EGFP.

Não foi possível verificar a integração do transgene nos espermatozóides por hibridização in situ, e comprovar a veiculação nuclear do transgene. No entanto, a presença de sequências de DNA interiorizadas às células espermáticas pode ser comprovada e quantificada por PCR em tempo real. A expressão do transgene em uma porcentagem dos embriões evidencia a veiculação das moléculas exógenas durante o processo de fecundação in vitro. A propagação extra-cromossomal das moléculas exógenas é um evento descrito para espermatozóides que acarretaria eventos de mosaisimo (SPADAROFA, 2008). Pode ser observado neste trabalho, que embriões gerados a partir de espermatozóides eletroporados apresentam maior número de blastômeros com marcação para o transgene, sugerindo evento de integração em estágio inicial de desenvolvimento embrionário. Este achado confirma a hipótese de que embriões gerados por espermatozóides eletroporados apresentem maior expressão do transgene.

Não se pode pormenorizar a importância da via de membrana, visto que grandes resultados tem sido alcançados com uso de ICSI na TGME em bovinos (VICHERA et al., 2010). Este fato demonstra que a membrana plasmática dos espermatozóides é um importante sinalizador para que a célula espermática quando em contato com DNA exógeno possa preparar mecanismos de defesa e de controle de entrada, preservando a integridade do genoma paterno 


\section{CONCLUSÕES}

Os resultados do presente estudo permitem concluir que:

É possível quantificar o número de cópias de DNA captadas e interiorizadas pelas células espermáticas.

A viabilidade dos espermatozóides não foi afetada pela adição de distintas concentrações de DNA exógeno.

O método de eletroporação causa alterações mitocondriais nas células espermaticas, sem no entanto, afetar a capacidade fecundante.

O gradiente de densidade (Percoll) é eficiente na remoção de proteínas do plasma seminal (IF-1).

Os protocolos de TGME utilizado produzem embriões que expressam o gene EGFP, sendo esta inferior à taxa de recombinação detectado pela PCR.

É possível localizar, por hibridização in situ, a disposição do inserto no genoma de embriões produzidos in vitro. Já para os espermatozóides bovinos (Bos indicus), tal ferramenta ainda não está validada, necessitando de ajuste no protocolo 
ANDREEVA, L. E.; SLEPTSOVA, L. A.; GRIGORENKO, A. P.; GAVRIUSHKIN, A. V.; KUZNETSOV, A. V. [Loach spermatozoa transfer foreign DNA, which expression is discovered in the early development stages]. Genetic, v. 39, n. 6, p. 758-761, 2003.

ANZAR, M.; BUHR, M. M.; Spontaneous uptake of exogenous DNA by bull spermatozoa. Theriogenology, v. 65, p. 683-690, 2006.

ATKINSON, P. W.; HINES, E. R.; BEATON, S.; MATTHAEI, K. I.; REED, K. C.; BRADLEY, M. P. Association of exogenous DNA with cattle and insect spermatozoa in vitro. Molecular Reproduction and Development, v. 29, p. 1-5, 1991.

BAAS, J. W.; MOLAN, P. C.; SHANNON, P. Factors in seminal plasma of bulls that effect the viability and motility of spermatozoa. Journal of Reproduction and Fertility, v. 68, p. 275-280, 1983.

BACHILLER, D.; SCHELLANDER, K.; PCLI, J.; RUETHER, U. Liposome-mediated DNA uptake by sperm cells. Molecular Reproduction and Development, v. 30, p. 194-200, 1991.

BACCI, M.L.; ZANNONI, A.; DE CECCO, M.; FANTINATI, P.; BERNARDINI, C.; GALEATI, G.; SPINACI, M.; GIOVANNONI, R.; LAVITRANO, M.; SEREN, E.; FORNI,M. Sperm-mediated gene transfer-treated spermatozoa maintain good quality parameters and in vitro fertilization ability in swine.Theriogenology, v. 72, p. 1163-1170, 2009.

BRACKETT, B. G.; BARANSKA, W.; SAWICKI, W.; KOPROWSKI, H. Uptake of heterologous genome by mammalian spermatozoa and its transfer to ova through fertilization. Proceedings of the National Academy of Sciences U.S.A., v. 68, n. 2, p. 353-357, 1971.

CANOVAS, S.; GUTIERREZ-ADAN, A.; GADEA, J. Effect of exogenous DNA on bovine sperm functionality using the sperm mediated gene transfer (SMGT) technique. Molecular Reproduction and Development, In Press, 2010.

CAPPELLO, F.; STASSI, G.; LAZZERESCHI, D.; RENZI, L.; DI, S. C.; MARFE, G.; GIANCOTTI, P.; WANG, H. J.; STOPPACCIARO, A.; FORNI, M.; BACCI, M. L.; TURCHI, V.; SINIBALDI, P.; ROSSI, M.; BRUZZONE, P.; PRETAGOSTINI, R.; DELLA, C. G.; CORTESINI, R.; FRATI, L.; LAVITRANO, M. hDAF expression in hearts of transgenic pigs obtained by sperm-mediated gene transfer. Transplantation Proceedings, v. 32, n. 5, p. 895-896, 2000.

CELEBI, C.; GUILLAUDEUX, T.; AUVRAY, P.; VALLET-ERDTMANN, V.; JEGOU, B. The making of "transgenic spermatozoa". Biology of Reproduction, v. 68, n. 5, p. $1477-1483,2003$. 
CHAN, A. W. S.; LUETJENS, C. M.; DOMINKO, T.; RAMALHO-SANTOS, J. O.; SIMERLY, C. R.; HEWITSON, L.; SCHATTEN, G. Foreign DNA Transmission by ICI: injection of spermatozoa bound with exogenous DNA results in embryonic GFP expression and live Rhesus monkey births. Molecular Human Reproduction, v. 6, n. 1, p. 26-33, 2000.

CHANG, K.; QIAN, J.; JIANG, M.; LIU, Y. H.; WU, M. C.; CHEN, C. D.; LAI, C. K.; LO, H. L.; HSIAO, C. T.; BROWN, L.; BOLEN, J., JR.; HUANG, H. I.; HO, P. Y.; SHIH, P. Y.; YAO, C. W.; LIN, W. J.; CHEN, C. H.; WU, F. Y.; LIN, Y. J.; XU, J.; WANG, K. Effective generation of transgenic pigs and mice by linker based spermmediated gene transfer. BMC Biotechnology, v. 2, p. 5, 2002.

DADOUNE, J. Spermatozoal RNAs: What About Their Functions? Microscopy research and technique, v. 72, p. 536-551, 2009.

EVENSON, D. P.; JOST, L. Sperm chomatin structure assay in useful for fertility assessment. Methods in cell Science, v. 22, p. 169-189, 2000.

FARRE, L.; RIGAU, T.; MOGAS, T.; GARCIA-ROCHA, M.; CANAL, M.; GOMEZFOIX, A. M.; RODRIGUEZ-GIL, J. E. Adenovirus-mediated introduction of DNA into pig sperm and offspring. Molecular Reproduction and Development, v. 53, n. 2, p. 149-158, 1999.

FEITOSA, W. B.; MILAZZOTO, M. P.; SIMÕES, R.; ROVEGNO, M.; NICACIO, A. C.; NASCIMENTO, A. B.; GONÇALVES, J. S. A.; VISINTIN, J. A.; ASSUMPÇÃO, M. E. A. Bovine sperm cell viability during incubation with or without exogenous DNA. Zycote, v. 23, n. 3, p. 1-6, 2009.

FEITOSA, W.B.; MENDES, C.M.; MILAZZOTTO, M.P.; ROCHA, A.M.; MARTINS, L.F.; SIMÕES, R.; PAULA-LOPES, F.F.; VISINTIN, J.A.; ASSUMPÇÃO, M.E. Exogenous DNA uptake by bovine spermatozoa does not induce DNA fragmentation. Theriogenology, In Press, 2010.

FERNANDEZ, M. A.; MANI, S. A.; RANGARAJAN, P. N.; SESHAGIRI, P. B. Sperm-mediated gene transfer into oocytes of the golden hamster: assessment of sperm function. Indian Journal of Experimental Biology, v. 37, n. 11, p. 10851092, 1999.

FRANCOLINI, M.; LAVITRANO, M.; LAMIA, C. L.; FRENCH, D.; FRATI, L.; COTELLI, F.; SPADAFORA, C. Evidence for nuclear internalization of exogenous DNA into mammalian sperm cells. Molecular Reproduction and Development, v. 34, p.133-139, 1993.

GAGNE, M. B.; POTHIER, F.; SIRARD, M. A. Electroporation of bovine spermatozoa to carry foreign DNA in oocytes. Molecular Reproduction and Development, v. 29, n. 1, p. 6-15, 1991.

GIORDANO, R.; MAGNANO, A. R.; ZACCAGNINI, G.; PITTOGGI, C.; MOSCUFO, N.; LORENZINI, R.; SPADAFORA, C. Reverse transcriptase activity in mature spermatozoa of mouse. Journal of Cell Biology, v. 148, p. 1107-1113, 2000.

HIRABAYASHI, M.; KATO, M.; ISHIKAWA, A.; KANEKO, R.; YAGI, T.; HOCHI, S. Factors affecting production of transgenic rats by ICSI-mediated DNA transfer: 
effects of sonication and freeze-thawing of spermatozoa, rat strains for sperm and oocyte donors, and different constructs of exogenous DNA. Molecular Reproduction and Development, v. 70, n. 4, p. 422-428, 2005.

HODGSON, C. P.; CHAKRABORTY, A. K.; ZINK, M. A.; XU, G. Construction, transmission and expression of synthetic VL30 vectors. In: Hodgson CP, editor. Retro-vectors for human gene therapy. New York: Chapman and Hall. p 103128, 1996.

HOELKER, M.; MEKCHAY, S.; SCHNEIDER, H.; BRACKET, B. G.; TESFAYE, D.; JENNEN, D.; THOLEN, E.; GILLES, M.; RINGS, F.; GRIESE, J.; SCHELLANDER, K. Quantification of DNA binding, uptake, transmission and expression in bovine sperm mediated gene transfer by RT-PCR: effect of transfection reagent and DNA architecture. Theriogenology, v. 67, n. 6, p. 1097-1107, 2007.

HUANG, Y. J.; HUANG, Y.; BALDASSARRE, H.; WANG, B.; LAZARIS, A.; LEDUC, M.; BILODEAU, A. S.; BELLEMARE, A.; COTE, M.; HERSKOVITS, P.; TOUATI, M.; TURCOTTE, C.; VALEANU, L.; LEMEE, N.; WILGUS, H.; BEGIN, I.; BHATIA, B.; RAO, K.; NEVEU, N.; BROCHU, E.; PIERSON, J.; HOCKLEY, D. K.; CERASOLI, D. M.; LENZ, D. E.; KARATZAS, C. N.; LANGERMANN, S. Recombinant human butyrylcholinesterase from milk of transgenic animals to protect against organophosphate poisoning. Proceedings of National Academy U.S.A., v. 104, n. 34, p. 13603-13608, 2007.

HUGUET, E.; ESPONDA, P. Generation of genetically modified mice by spermatozoa transfection in vivo: preliminary results. Molecular Reproduction and Development, v. 56, n. 2, p. 243-247, 2000.

IJDO, J. W.; WELLS, R. A.; BALDINI, A.; REEDERS, S. T. Improved telomere detection using a telomere repeat probe (TTAGGG)n generated by PCR. Nucleic Acids Research v.19, p.4780, 1991 b.

IKAWA, A. M.; KOMINAMI, A. K.; YOSHIMURA, A. Y.; TANAKA, B. K.; NISHIMUNE, A. Y.; OKABE, A. M. A rapid and non-invasive selection of transgenic embryos before implantation using green fluorescent protein (GFP). Federation of European Biochemical Societies, v. 375, p. 125-128, 1995.

KANEKO, T.; MOISYADI, S.; SUGANUMA, R.; HOHN, B.; YANAGIMACHI, R.; PELCZAR, P. Recombinase-mediated mouse transgenesis by intracytoplasmic sperm injection. Theriogenology, v. 64, p. 1704-1715, 2005.

KANG, J. H.; HAKIMOV, H.; RUIZ, A.; FRIENDSHIP, R. M.; BUHR, M.; GOLOVAN, $S$. P. The negative effects of exogenous DNA binding on porcine spermatozoa are caused by removal of seminal fluid. Theriogenology, v. 6, p.1-9, 2008.

KATO, M.; ISHIKAWA, A.; KANEKO, R.; YAGI, T.; HOCHI, S.; HIRABAYASHI, M. Production of transgenic rats by ooplasmic injection of spermatogenic cells exposed to exogenous DNA: a preliminary study. Molecular Reproduction and Development, v. 69, n. 2, p. 153-158, 2004.

KHOO, H. W.; ANG, K. H.; WONG, K. Y. Sperm cells as vectors for introducing foreign DNA into zebrafish. Aquaculture, v. 107, p.1-19, 1992. 
KOO, B. C.; KWON, M. S.; CHOI, B. R.; LEE, H. T.; CHOI, H. J.; KIM, J. H.; KIM, N. H.; JEON, I.; CHANG, W.; KIM, T. Retrovirus-mediated gene transfer and expression of EGFP in chicken. Molecular Reproduction and Development, v. 68, n. 4, p. 429-434, 2004.

KUZNETSOV, A. V.; KUZNETSOVA, I. V.; SCHIT, I. Y. DNA interaction with rabbit sperm cells and its transfer into ova in vitro and in vivo. Molecular Reproduction and Development, v. 56, n. 2, p. 292-297, 2000.

KUZNETSOV, A. V.; SHCHIT, I. I.; KUZNETSOVA, I. V.; DVORIANCHIKOV, G. A. [The transfer of foreign DNA by rabbit spermatozoa into hamster eggs]. Ontogenez, v. 30, n. 6, p. 405-410, 1999.

LAVITRANO, M.; FORNI, M.; BACCI, M. L.; DI, S. C.; VARZI, V.; WANG, H.; SEREN, E. Sperm mediated gene transfer in pig: Selection of donor boars and optimization of DNA uptake. Molecular Reproduction and Development, v. 64, n. 3, p. 284-291, 2003.

LAVITRANO, M.; FORNI, M.; VARZI, V.; PUCCI, L.; BACCI, M. L.; DI, S. C.; FIORETTI, D.; ZORAQI, G.; MOIOLI, B.; ROSSI, M.; LAZZERESCHI, D.; STOPPACCIARO, A.; SEREN, E.; ALFANI, D.; CORTESINI, R.; FRATI, L. Spermmediated gene transfer: production of pigs transgenic for a human regulator of complement activation. Transplantation Proceedings, v. 29, n. 8, p. 3508-3509, 1997a.

LAVITRANO, M.; MAIONE, B.; FORTE, E.; FRANCOLINI, M.; SPERANDIO, S.; TESTI, R.; SPADAFORA, C. The interaction of sperm cells with exogenous DNA: a role of CD4 and major histocompatibility complex class II molecules. Experimental Cell Research, v. 233, n. 1, p. 56-62, 1997b.

LIU, C.; TSAO, H.; CHENG, T.; WU, H.; HUANG, C.; CHEN, C.; LIN, D. P.; LEE M. DNA Fragmentation, Mitochondrial Dysfunction and Chromosomal Aneuploidy in the Spermatozoa of Oligoasthenoteratozoospermic Males. Journal of Assisted Reproduction and Genetics, v. 21, p-119-126, 2004.

MA, H.; QUAN, F.; CHEN, D.; ZHANG, B.; ZHANG Y. Alterations in mitochondrial function and spermatozoal motility in goat spermatozoa following incubation with a human lysozyme plasmid. Animal Reproduction Science, v. 121, p. 106-114, 2010.

MAGNANO, A. R.; GIORDANO, R.; MOSCUFO, N.; BACCETTI, B.; SPADAFORA, C. Sperm/DNA interaction: integration of foreign DNA sequences in the mouse sperm genome. Journal of Reproduction Immunology, v. 41, p. 187-96, 1998.

MAIONE, B.; LAVITRANO, M.; SPADAFORA, C.; KIESSLING, A. A. Spermmediated gene transfer in mice. Molecular Reproduction and Development, $v$. 50, n. 4, p. 406-409, 1998.

MARTINEZ-PASTOR, F.; JOHANNISSON, A.; GIL, J.; KAABI, M.; ANEL, L.; PAZ, P.; RODRIGUES-MARTINEZ, $H$. Use of chromatin stability assay, mitochondrial stain JC-1, and fluorometric assessment of plasma membrane to evaluate frozenthawed RAM semen. Animal Reproduction Science, v. 84, p. 121-133, 2004. 
NAGANO, M.; BRINSTER, C. J.; ORWIG, K. E.; RYU, B. Y.; AVARBOCK, M. R.; BRINSTER, R. L. Transgenic mice produced by retroviral transduction of male germ-line stem cells. Proceedings of National Academy of Science U.S.A, v. 98, n. 23, p. 13090-13095, 2001.

NIWA, H.; YAMAMURA, K.; MIYAZAKI, J. Efficient selection for high-expression transfectants with a novel eukaryotic vector. Gene, v. 108, p. 193-199, 1991.

NORTHROP, J. P.; RINGOLD, G. M.; DANIELSEN, M. Lipofection: a highly efficient, lipid-mediated DNA-transfection procedure. Proceedings of National Academy of Science U.S.A, v. 21, p. 7413-7417, 1987.

PATIL, J. G.; KHOO, H. W. Nuclear Internalization of Foreign DNA by Zebrafish Spermatozoa and Its Enhancement by Electroporation. Journal of Experimental Zoology, v. 274, p. 121-129, 1996.

PEREYRA-BONNET, F.; FERNÁNDEZ-MARTÍN, R.; OLIVERA, R.; JARAZO, J.; VICHERA, G.; GIBBONS, A.; SALAMONE, D. A unique method to produce transgenic embryos in ovine, porcine, feline, bovine and equine species. Reproduction, Fertility and Development, v. 20, p. 741-749, 2008.

PITTOGGI, C.; BERALDI, R.; SCIAMANNA, I.; BARBERI, L.; GIORDANO, R.; MAGNANO, A. R.; TOROSANTUCCI, L.; PESCARMONA, E.; SPADAFORA, C. Generation of Biologically Active Retro-genes Upon Interaction of Mouse Spermatozoa With Exogenous DNA. Molecular Reproduction and Development, v. 73, p. 1239-1246, 2006.

RIETH, A.; POTHIER, F.; SIRARD, M. Electroporation of Bovine Spermatozoa to Carry DNA Containing Highly Repetitive Sequences Into Oocytes and Detection of Homologous Recombination Events. Molecular Reproduction and Development, v. 57 , p. $338-345,2000$.

ROSSATO, M.; VIRGILIO, F. D.; RIZZUTO, R.; GALEAZZI, C.; FORESTA, C. Intracellular calcium store depletion and acrosome reaction in human spermatozoa: role of calcium and plasma membrane potential. Molecular Human Reproduction, v. 7, n. 2, p. 119-128, 2001.

SCIAMANNAS, I.; PICCOLI, S.; BARBERI, L.; ZACCAGNINI, G.; MAGNANO, A. R.; GIORDANO, R.; CAMPEDELLI, P.; HODGSON, C.; LORENZINI, R.; SPADAFORA, C. DNA Dose and Sequence Dependence in Sperm-Mediated Gene Transfer, Molecular Reproduction and Development, v. 56, p. 301-305, 2000.

SHEMESH, M.; GUREVICH, M.; HAREL-MARKOWITZ, E.; BENVENISTI, L.; SHORE, L. S.; STRAM, Y. Gene Integration Into Bovine Sperm Genome and Its Expression in Transgenic Offspring. Molecular Reproduction and Development, v. 56, p. 306-308, 2000.

SHEN, W.; LI, L.; PAN, Q.; MIN, L.; DONG, H.; DENG, J. Efficient and Simple Production of Transgenic Mice and Rabbits Using the New DMSO-Sperm Mediated Exogenous DNA Transfer Method. Molecular Reproduction and Development, v. 73, p. 589-594, 2006. 
SHINOHARA, E. T.; KAMINSKI, J. M.; SEGAL, D. J.; PELCZAR, P.; KOLHE, R.; RYAN, T.; COATES, C. J.; FRASER, M. J.; HANDLER, A. M.; YANAGIMACHI, R.; MOISYADI, S. Active integration: new strategies for transgenesis, Transgenic Research, v. 16, p. 333-339, 2007.

SIN, F. Y.; WALKER, S. P.; SYMONDS, J. E.; MUKHERJEE, U. K.; KHOO, J. G.; SIN, I. L. Electroporation of salmon sperm for gene transfer: efficiency, reliability, and fate of transgene. Molecular Reproduction and Development, v. 56, n. 2, p. 285-288, 2000.

SPADAFORA, C. Sperm-mediated 'reverse' gene transfer: a role of reverse transcriptase in the generation of new genetic information. Human Reproduction, v. 11, p. $735-740,2008$.

SPADAFORA, C. Sperm cells and foreign DNA: a controversial relation. BioEssays, v. 20, p. 55-964, 1998.

SUGANUMA, R.; PELCZAR, P.; SPETZ, J. F.; HOHN, B.; YANAGIMACHI, R.; MOISYADI, S. Tn5 Transposase-Mediated Mouse Transgenesis. Biology of Reproduction, v. 73, p. 1157-1163, 2005.

TSAI, H. J.; LAI, C. H.; YANG, H. S. Sperm as a carrier to introduce an exogenous DNA fragment into the oocyte of Japanese abalone (Haliotis divorsicolor suportexta). Transgenic Research, v. 6, n. 1, p. 85-95, 1997.

VALENZUELA, M.; RELLOSO, M.; ESPONDA, P. In vivo transfection of the mouse vas deferens. Journal of Experimental Zoology, v. 293, n. 5, p. 532-540, 2002.

VASICEK, D.; VASICKOVA, K.; PARKANYI, V.; RAFAY, J.; ONDRUSKA, L. Effective generation of genetically modified rabbits by sperm mediated gene transfer. World Rabbit Science, v. 15, p. 161-166, 2007.

VICHERA, G.; MORO, L.; SALAMONE, D. Efficient Transgene Expression in IVF and Parthenogenetic Bovine Embryos by Intracytoplasmic Injection of DNALiposome Complexes. Reproduction in Domestic Animal, In Press, 2010.

VORSANOVA, S. G.; YUROV, Y. B.; IOUROV, I. Y. Human interphase chromosomes: a review of available molecular cytogenetic technologies. Molecular Cytogenetics, v. 3, p. 1, 2010.

VORSANOVA, S. G.; YUROV, Y. B.; IOUROV, I. Y. Recent patents on molecular cytogenetics. Recent Patents on DNA Gene Sequences, v. 2, p. 6-15, 2008.

WALL, R. J. New gene transfer methods. Theriogenology, v. 57, n. 1, p. 189-201, 2002.

WHYTE, J. J.; ROBERTS, R. M.; ROSENFELD, C. S. Fluorescent in situ hybridization for sex chromosome determination before and after fertilization in mice. Theriogenology, v. 15, n. 67, p. 1022-1031, 2007.

YONEZAWA, T.; FURUHATA, Y.; HIRABAYASHI, K.; SUZUKI, M.; TAKAHASHI, M.; NISHIHARA, M. Detection of transgene in progeny at different developmental stages following testis-mediated gene transfer. Molecular Reproduction and Development, v. 60, p. 196-201, 2001. 
ZANI, M.; LAVITRANO, M.; FRENCH, D.; LULLI, V.; MAIONE, B.; SPERANDIO, S.; SPADAFORA, C. The Mechanism of binding of Exogenous DNA to sperm Cells: Factors controlling the DNA Uptake. Experimental Cell Research, v. 217, p. 5764, 1995.

ZORAQI, G.; SPADAFORA, C. Integration of foreign DNA sequences into mouse sperm genome. DNA Cell Biology, v. 16, p. 291-300, 1997. 


\section{APÊNDICES}

Os protocolos de cada etapa deste trabalho foram colocados em apêndices para que possam ser reproduzidos.

\subsection{APÊNDICE 1}

\section{Vetor recombinante pCX-EGFP}

A construção gênica utilizada neste trabalho foi o vetor recombinante $\mathrm{pCX}$ EFGP, sendo este doado ao Laboratório de Fecundação In vitro, Clonagem e Transgenese Animal pelo professor Dr. Masaru Okabe do Centro de Pesquisa em Informações Genômicas da Universidade de Osaka - Japão. O pCX-EGFP carrega uma variante vermelha e humanizada da proteína verde fluorescente (EGFP) que otimiza uma fluorescência mais brilhante e uma expressão mais elevada em células eucarióticas (excitação de 480 - 507 nanômetros). Neste vetor, a região promotora e o primeiro íntron do gene da $\beta$-Actina de galinha foram clonados entre a região codificadora da EGFP e a região promotora de citomegalovírus (CMV), Figura 22.

O vetor recombinante pCX-EGFP foi escolhido por apresentar alta eficiência na expressão do gene repórter GFP (green fluorescent protein). O uso da GFP foi descrito por Ikawa et al. (1995) quando reportaram o desenvolvimento de uma técnica não invasiva para selecionar embriões transgênicos. Estes autores clonaram o gene da "Green Fluorescent Protein" (GFP), isolado do hidrozoário Aequorea Victoria, no vetor de expressão pCAGGs (NIWA et al., 1991). O novo vetor, contendo a GFP, recebeu o nome de pCX-EGFP e vem sendo utilizado por diversos autores, principalmente em trabalhos que buscam desenvolver métodos para a geração de animais transgênicos. 


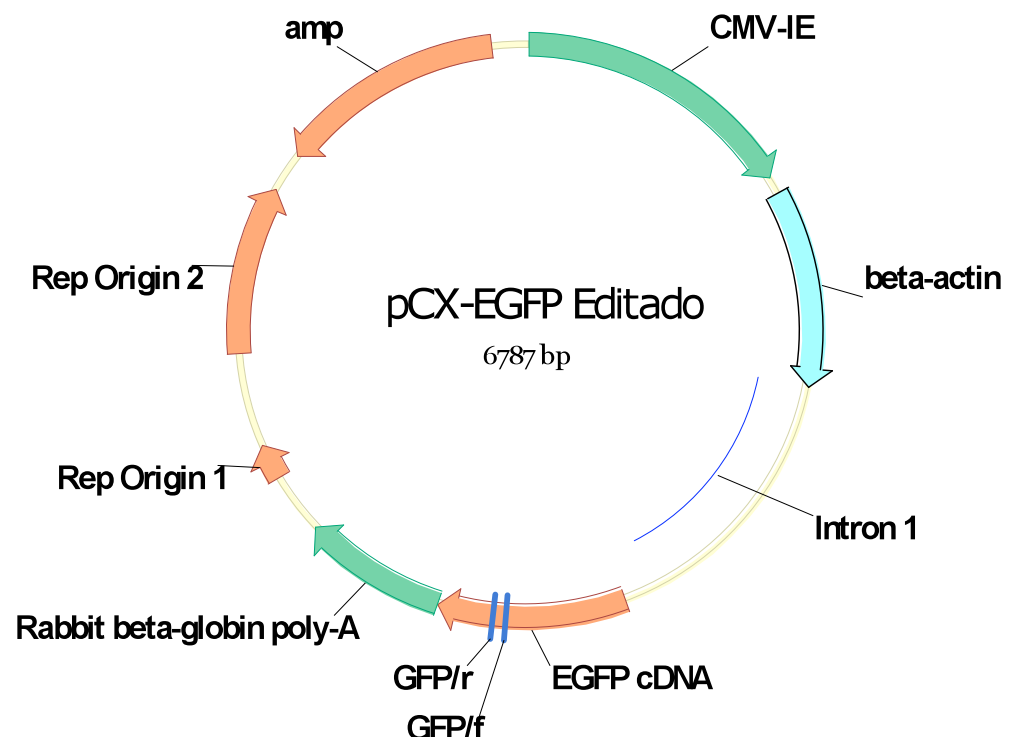

Figura 22 Diagrama do vetor pCX-EGFP. Seta verde superior corresponde à região promotora de citomegalovírus (CMV-IE); seta azul demarca a sequência promotora do gene da betaactina de galinha (beta-actin); linha azul corresponde ao primeiro íntron do gene de beta-actina de galinha (íntron 1); seta laranja inferior demarca a região codificadora do gene da GFP (EGFP cDNA).

Pereyra-Bonnet et al. (2008) demonstraram que o vetor pCX-EGFP é capaz de expressar o gene da GFP em embriões de cinco espécies de animais domésticos (ovino, suíno, felino, bovino e eqüino).

Inicialmente foi realizada uma eletroforese em gel de agarose à $0,8 \%$, com marcador de peso e massa molecular visando certificar-se da presença e integridade do vetor (Figura 23).

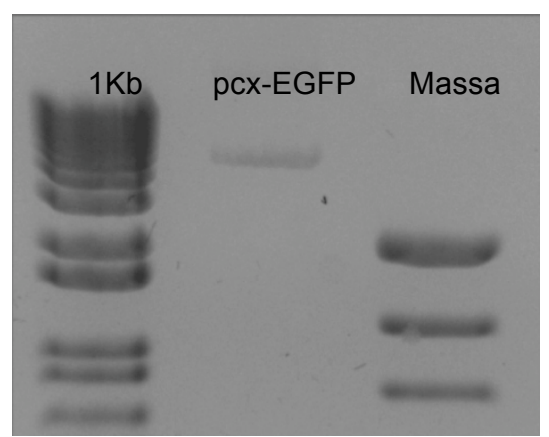

Figura 23 Eletroforese do vetor pCX-EGFP, $0,1 \mathrm{ug} / \mathrm{ul}$ em gel de agarose a 0,8\%; $1 \mathrm{~kb}$ - marcador de 1 quilo base; Mass - Marcador de massa molecular (Invitrogen).

Posteriormente foi realizada a transformação de células competentes de $E$. Coli TOP10 com o plasmídio, submetendo-as ao choque térmico. Para isso foi 
utilizada 0,1ug do vetor plasmidial pcx-EGFP. A desestabilização da membrana plasmática das células, visando possibilitar a entrada do DNA foi realizada colocando a cultura bacteriana em água a $42^{\circ} \mathrm{C}$ por 1 minuto, sendo adicionado $\mathrm{CaCl}_{2}(100 \mu \mathrm{l}$ a $100 \mathrm{mM})$ e DNA, seguido por incubação em gelo, por 30 minutos, finalizando o choque térmico.

Após esta etapa foi realizado o plaqueamento de $10 \mu \mathrm{l}$ da cultura em meio LB sólido (Invitrogen, cat no. 22700-025 ), contendo ampicilina (100 $\mu \mathrm{g} / \mathrm{ml}$, Gibco, cat. No. 11593-019). O antibiótico faz a seleção das colônias positivas para o vetor, uma vez que somente as células que capturarem o vetor podem crescer em meio contendo esse antibiótico.

Esse cultivo foi mantido por 24 horas à $37^{\circ} \mathrm{C}$. Ao fim deste período foi observado o desenvolvimento de quatro colônias. Estas foram analisadas pela técnica de PCR (polymerase chain reaction) utilizando primers específicos para a sequência da GFP (green fluorescent protein), com o intuito de identificar os clones positivos. O produto desta reação foi visualizado por eletroforese em gel de agarose $(0,8 \%)$ (Figura 24$)$.

As quatro colônias foram positivas para a presença do vetor, sendo que a reação foi específica e sem contaminantes.

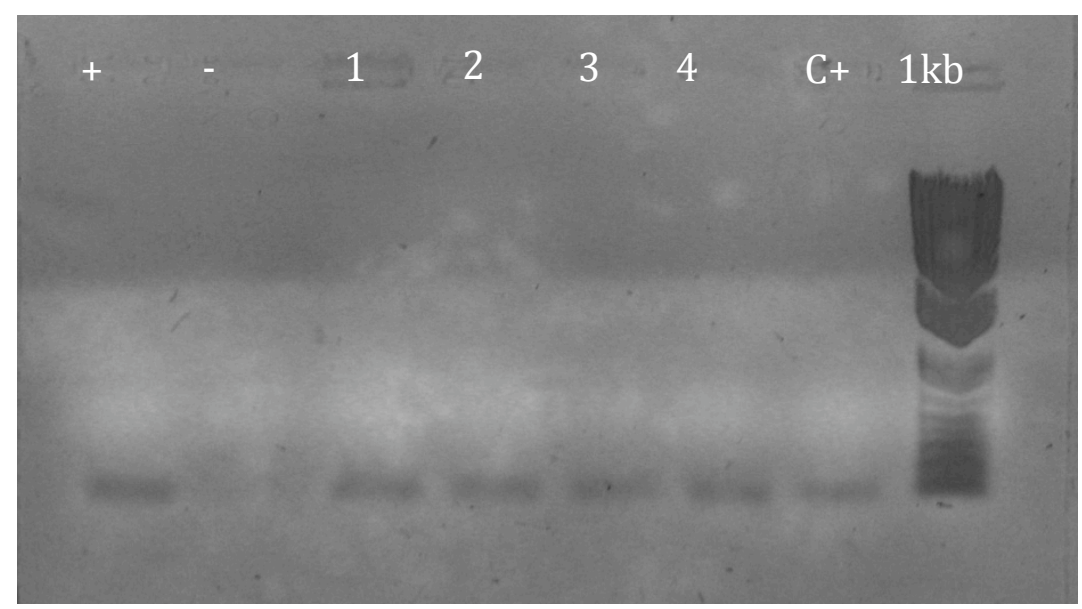

Figura 24 Gel de agarose $(0,8 \%)$ dos produtos de PCR das colônias pCX- EGFP. $(+)$ controle positivo; (-) controle negativo; $(1,2,3,4)$ Colônias; $(C+)$ colônia mais vetor.

Após a confirmação da presença do vetor foi realizado um novo cultivo com as colônias positivas em meio LB líquido contendo antibiótico (100 $\mu \mathrm{g} / \mu \mathrm{l}$ de 
Ampicilina). Este cultivo foi centrifugado e o sedimento utilizado para a extração do DNA plasmidial (Figura 25) com o auxilio do kit Miniprep (Invitrogen Technologies). A quantificação do DNA plasmidial purificado foi realizada por espectrofotometria.

Os resultados das quantificações demonstraram que o produto purificado das Colônias 3 e 4 apresentaram maior concentração (160,9 e 138,0 ng/ul) respectivamente, sendo estas utilizadas para as etapas posteriores.

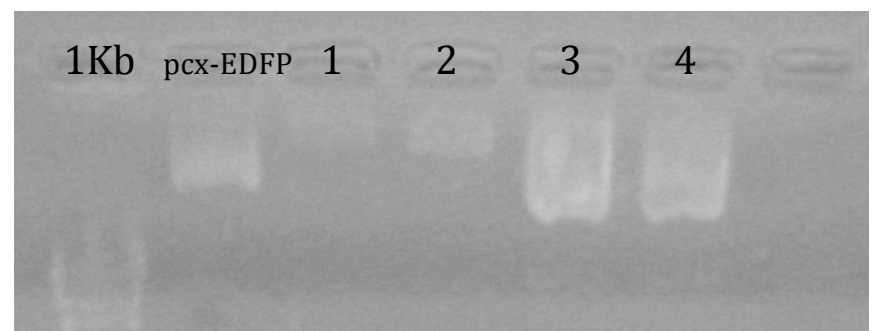

Figura 25 Análise Eletroforética em gel de agarose (0,8\%) da extração de DNA plasmidial; (1) 14,7 $\mathrm{ng} / \mu \mathrm{l}$; (2) $22,4 \mathrm{ng} / \mu \mathrm{l} ;(3) 160,9 \mathrm{ng} / \mu \mathrm{l} \mathrm{e} \mathrm{(4)} 138,0 \mathrm{ng} / \mu \mathrm{l}$.

A caracterização molecular do vetor foi realizada pela digestão do mesmo utilizando enzimas de restrição. As enzimas utilizadas foram Sall com EcoRI e HindIII com BamHI, ou seja, enzimas as quais o vetor pcx-EGFP possui sítios de restrição. A digestão ocorreu por 24 horas à 37 graus Celsius e o produto da digestão foi separado por eletroforese em gel de agarose, visando analisar o peso molecular dos produtos.

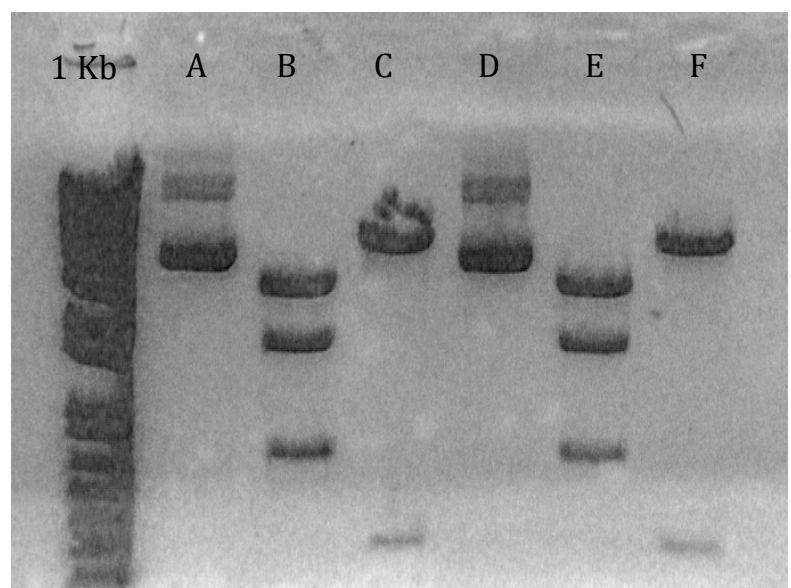

Figura 26 Análise da eletroforese em gel de agarose $(0,8 \%)$ dos fragmentos gerados após a digestão enzimática; A) Vetor Colônia 3 não digerido; B) Vetor colônia 3 digerido com as enzimas Sall e EcoRI; C ) Vetor colônia 3 digerido com as enzimas Hindlll e BamHI; D) Vetor Colônia 4 não digerido; E ) Vetor colônia 4 digerido com as enzimas Sall e EcoRI; F ) Vetor colônia 4 digerido com as enzimas Hindlll e BamHI; $1 \mathrm{~Kb}=$ marcador. 
A Figura 26 ilustra os três fragmentos gerados pela digestão das enzimas Sall e EcoRI apresentam peso molecular de 732, 1719 e 3059 pares de base, que correspondem aos fragmentos esperados para a reação. Os fragmentos de 185, 337 e 4988 pares de base também foram gerados após a digestão do DNA palsmidial com as enzimas HindlII e BamHI, o que confirmou a presença do vetor.

A linearização do pCX-EGFP foi a etapa final na preparação do vetor, que posteriormente foi utilizado para a transfecção das células espermáticas e a preparação das sondas de hibridização in situ.

Esta etapa foi realizada com o uso da enzima Stul, que corta o vetor no meio da região de origem de replicação. Deste modo o vetor passa para sua conformação linear, o que facilita a inserção no genoma hospedeiro. A Figura 27 demonstra os dois estados conformacionais do vetor, um linear no qual a migração no gel é dificultada (pela maior superfície a qual o vetor passa a possuir) e uma circular, a qual possui maior capacidade de migração (pela superfície reduzida).

Figura 27 Análise eletroforética em gel de agarose $(0,8 \%)$ dos estados conformacionais do vetor plasmidial pcx-EGFP. A) vetor linear após corte com a enzima Stul; B) Conformação circular - sem digestão enzimática. M) Marcador de $1 \mathrm{~Kb}$. 


\subsection{APÊNDICE 2}

\section{PCR em Tempo Real}

A reação de qPCR foi feita utilizando o kit SYBR GreenER qPCR Super Mix (Invitrogen Corporation@, Cat. No.11762-100), primers GFP/F e GFP/R (iten 5.1.1) e termociclador em tempo real (Realplex ${ }^{\circledR}$ Eppendorf). As condições da reação podem ser vistas na Figura 28.

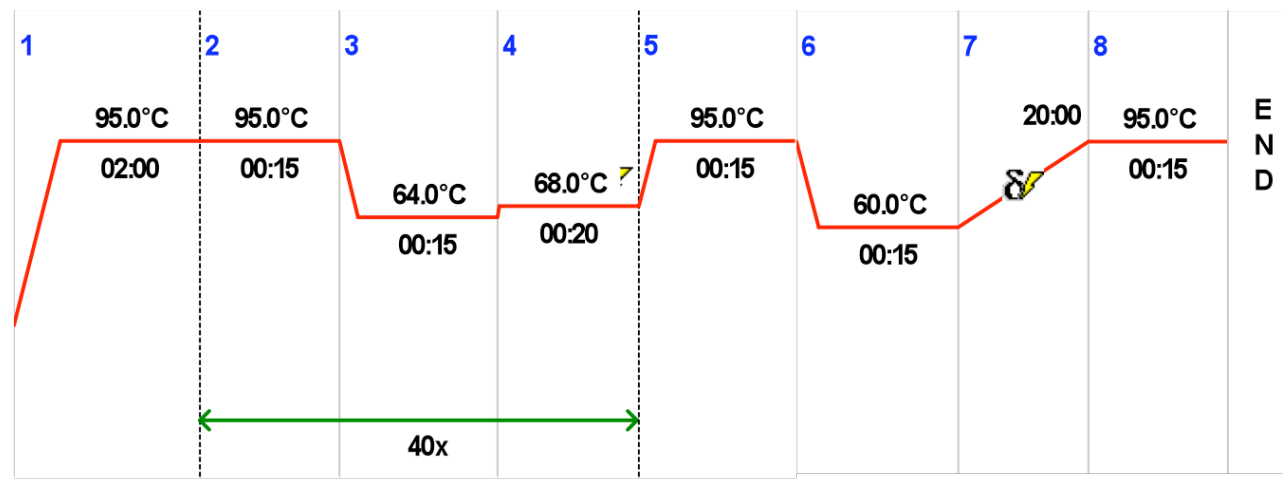

Figura 28 Descrição gráfica da relação temperatura pelo tempo da reação de qPCR. Passo 1 corresponde à desnaturação do DNA e ativação da DNA polimerase. Passos de 2 a 4 correspondem ao ciclo da reação que foi repetido por 40 vezes. Passos de 5 a 8 correspondem à curva de dissociação.

A curva controle de amplificação foi feita por diluição seriada (1:10) do plasmídio pCX-EGFP, iniciando com 2 ng e término na sexta diluição. Isso corresponde a uma curva que parte de 8.257.713 cópias do vetor e tem seu térmico com 82 cópias. A Figura 29 mostra a relação entre os ciclos de amplificação e o número de cópias da sequência EGFP do vetor pCX-EGFP, os pontos em vermelho correspondem às reações da curva controle, cruzes negras correspondem aos valores das amostras mensuradas. A Figura 30 exemplifica a relação fluorescência e ciclo de amplificação das reações, no qual cada linha corresponde a uma amostra. 


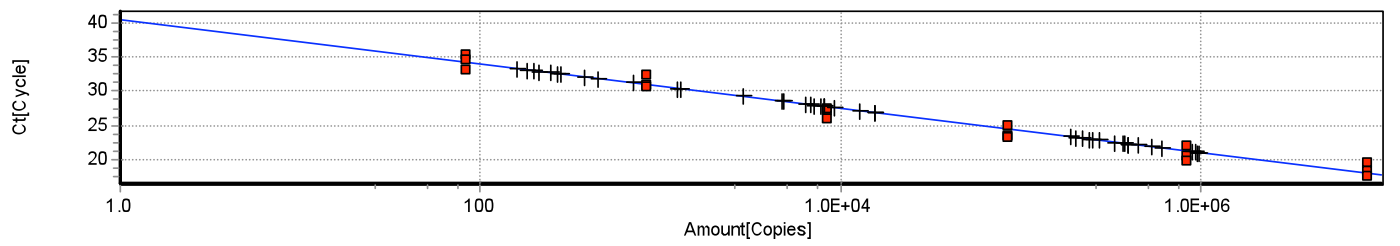

Figura 29 Relação entre ciclo de amplificação e número de cópias do vetor. Pontos vermelhos marcam as reações com concentrações de vetor conhecidas, cruzes negras marcam os valores da amostras mensuradas.

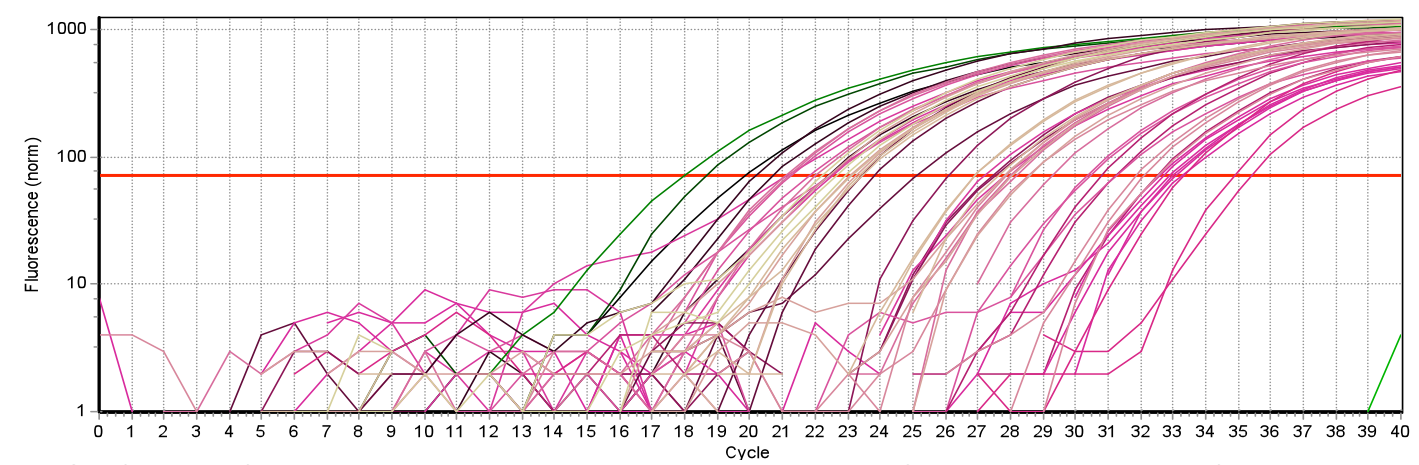

Figura 30 Gráfico da fluorescência pelo ciclo da reação de GPCR. As linhas de diferentes cores correspondem a amostras diferentes. Traço horizontal vermelho corresponde a linha de análise, pelo qual o valor de cada amostra é mensurado.

A curva de dissociação revelou a especificidade da reação, pois todos os amplificados obtiveram o mesmo ponto de dissociação, sendo que este ocorreu na temperatura de $80^{\circ} \mathrm{C}$ (Figura 31). Os fragmentos da GFP amplificados apresentam massa molecular de 67 pares de base com ponto de dissociação entre 79 e $81^{\circ} \mathrm{C}$. O controle negativo de amplificação da reação (linha verde) demonstrou ausência de contaminações.

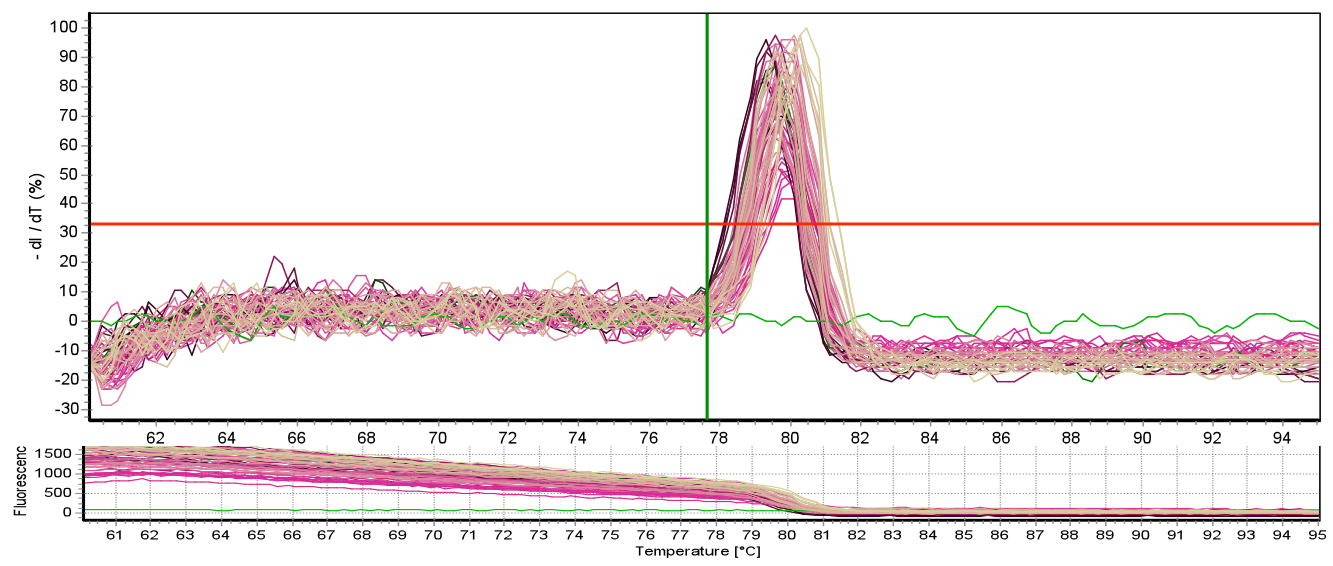

Figura 31 Curva de dissociação, pico à $80^{\circ} \mathrm{C}$ corresponde ao ponto de dissociação do fragmento amplificado. Traço verde corresponde ao controle negativo da reação. 


\subsection{APÊNDICE 3}

\section{Citometria de Fluxo}

A técnica de citometria de fluxo foi realizada utilizando o equipamento Guava Easycyte mini (Guava Technologies, Hayward, CA, USA) (processo FAPESP N ${ }^{0}$ 07/55294-8). O uso das sondas fluorescentes iodeto de propídio (PI) e aglutinina de Psium sativum conjugada com isioticionato de fluoresceína (FITCPSA) resultou na visualização de quatro distintas populações celulares. Uma população de células sem qualquer tipo de lesão; células com lesão na membrana acrossomal; células com lesão na membrana plasmática e células com lesão em ambas as membranas (Figura 32).

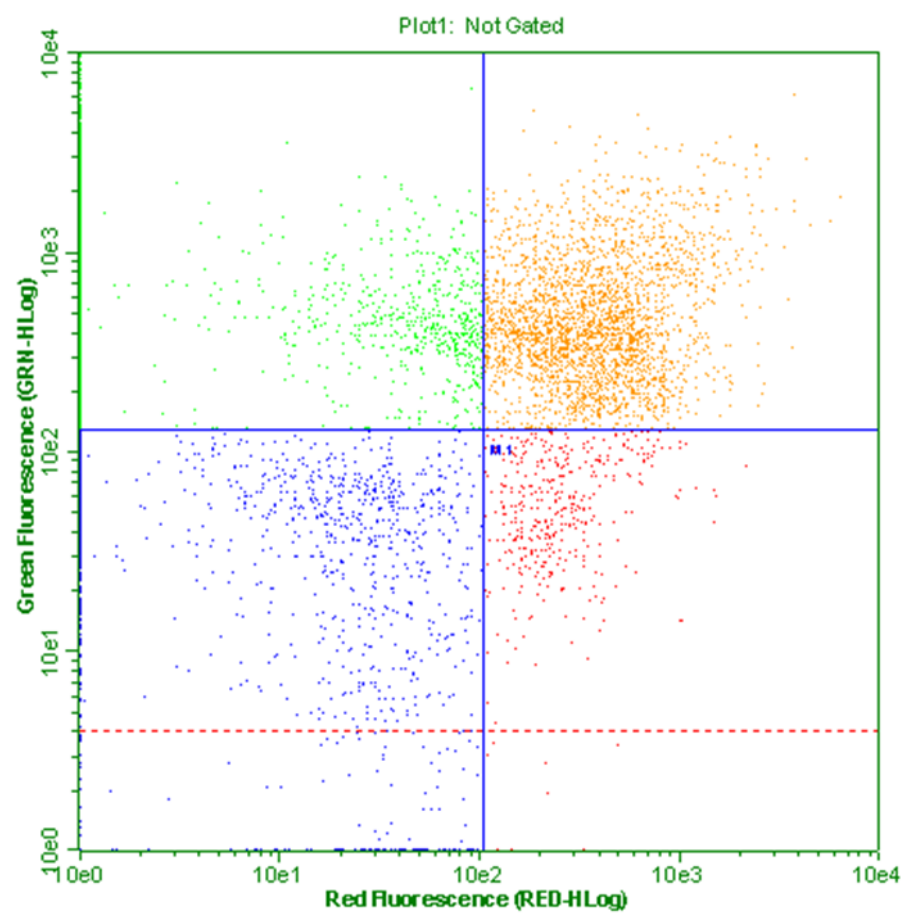

Figura 32 Dotplot de fluorescência verde por vermelho resultante da avaliação das células espermáticas com as sondas FITC-PSA juntamente com PI. Em azul estão as células íntegras sem qualquer tipo de lesão, em verde as células que sofreram apenas lesão na membrana acrossomal, em vermelho células com lesão somente na membrana plasmática e em laranja a população celular que sofreu lesões em ambas as membranas (plasmática e acrossomal)

A função mitocondrial foi verificada utilizando a sonda JC-1, que cora em vermelho as mitocôndrias com alto potencial de membrana e em verde as com baixo potencial (MARTINEZ-PASTOR et at., 2004). A Figura 33 evidencia as 
populações celulares observadas quando utilizada a sonda JC-1. Duas populações celulares bem delimitadas podem ser observadas no dotplot de fluorescência vermelho (eixo y) pelo verde (eixo $\mathrm{x}$ ). Células com alto potencial de membrana mitocondrial (APMM) formam uma delas no canto superior do dotplot e células com baixo potencial de membrana mitocondrial (BPMM) formam a segunda no canto inferior do dotplot. Entre essas duas populações celulares existem as células com intermediário potencial de membrana mitocondrial, no entanto, esta população celular apresenta uma dispersão maior, formando rastro.

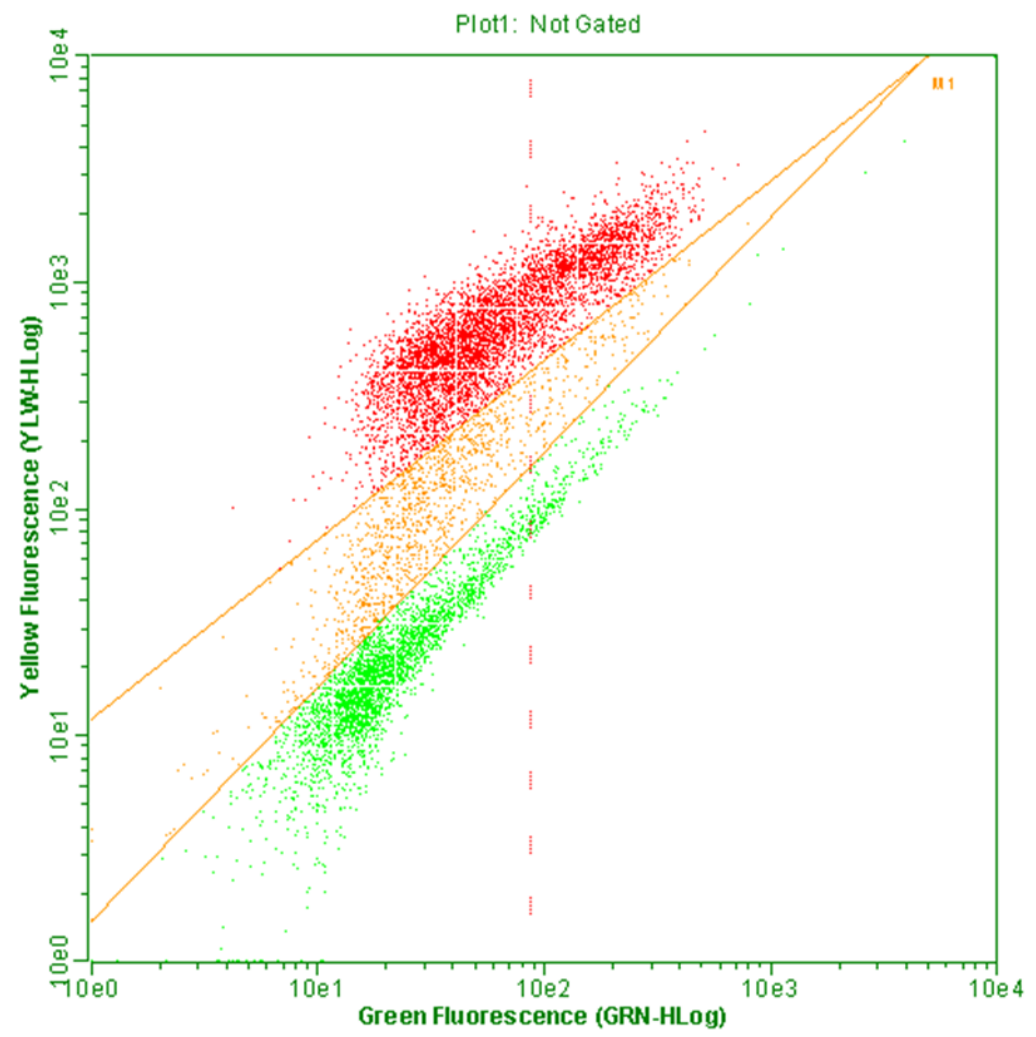

Figura 33 Dotplot da fluorescência verde pela amarela resultante da avaliação das células espermáticas com a sonda JC-1. Em vermelho a população de espermatozóides com alto potencial de membrana mitocondrial, em laranja as células com potencial de membrana mitocondrial intermediário e em verde células com baixo potencial de membrana mitocondrial

A dispersão celular da população de espermatozóides avaliada por ensaio de estrutura de cromatina espermática (SCSA) pode ser observado na Figura 34. Diferentemente das sondas descritas anteriormente, a análise da fragmentação de DNA espermático é realizada indiretamente pelo programa FlowJo (Flow Cytometry Analysis Software - Tree Star Inc., Ashland, Oregon, USA). Foi calculado o AlfaT de cada amostra, expressão resultante da razão da fluorescência vermelha pela 
fluorescência total [ $\alpha \mathrm{T}=$ =amarelo/(amarelo+verde)]. A porcentagem de DNA desnaturado da amostra é marcado manualmente à partir do histograma de $\alpha \mathrm{T}$ e recebe o nome de COMP $\alpha \mathrm{T}$ (do inglês, cells outside the main population). Adotouse como valores de referência os mesmos descritos por Evenson e Jost (2000), no qual COMP $\alpha \mathrm{T}$ entre $0-15 \%$ é considerado baixo índice de fragmentação (alta fertilidade), entre 16-29\% médio índice de fragmentação e $\geq 30 \%$ alta fragmentação (baixa fertilidade).
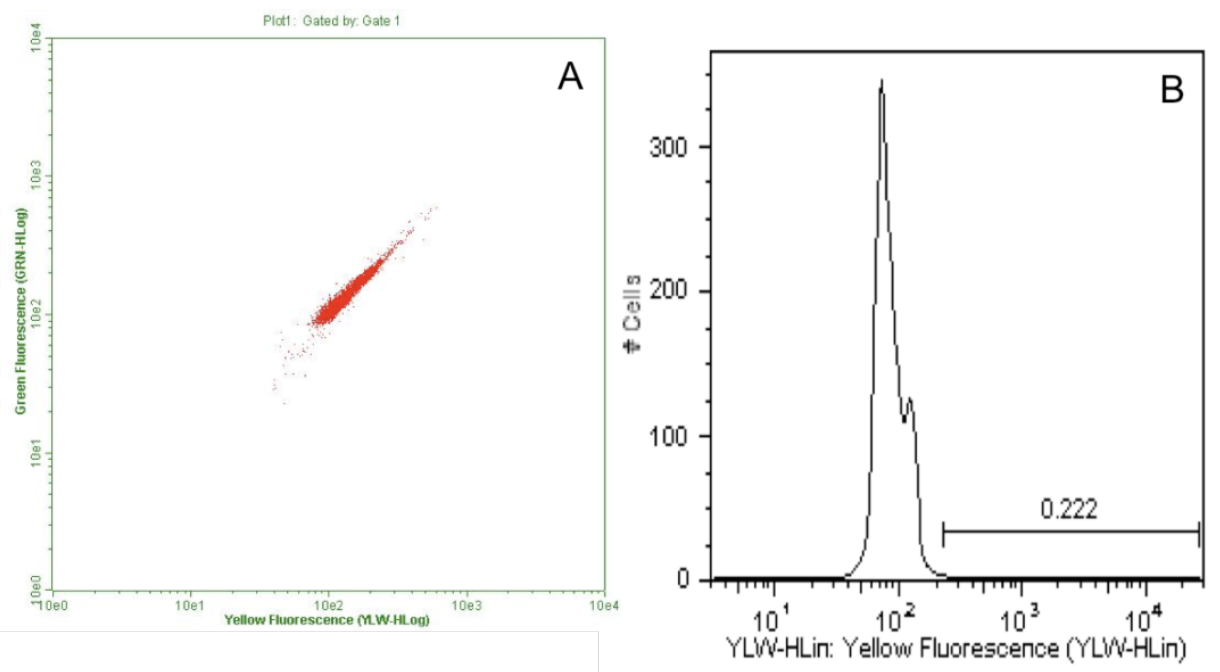

Figura 34 Exemplos de gráficos gerados pelo teste de SCSA. Em A, Dotplot da fluorescência verde pela amarela resultante da avaliação das células espermáticas no Ensaio de Estrutura de Cromatina. Em vermelho a dispersão da população de espermatozóides. Em B, histograma correspondente de $\alpha \mathrm{T}$, entre barras está o valor de COMP $\alpha \mathrm{T}$. 


\subsection{APÊNDICE 4}

\section{Preparo de sondas marcadas para Hibridização}

Para a construção das sondas marcadas uma reação contendo $10 \mu \mathrm{g}$ do vetor recombinante pCX-EGFP e $40 \mu$ l DIG-Nick Translation Mix foi incubada em termociclador (eppendorf Mastercicle) por 4 horas a $15^{\circ} \mathrm{C}$. Após este período, a reação foi mantida em gelo e uma alíquota de $3 \mu$ foi retirada para a realização de uma eletroforese (Figura 35).

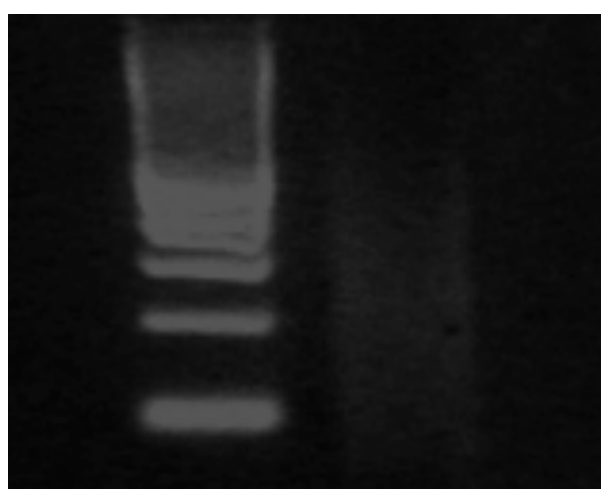

Figura 35 Eletroforese em gel de agarose a $0,8 \%$ do produto da reação de Nick translation após 4 horas de incubação a $15^{\circ} \mathrm{C}$. À esquerda, marcador de massa molecular de $1 \mathrm{~kb}$ (invitrogen). À direita, os fragmentos do vetor entre a faixa de $3 \mathrm{~kb}$ a $100 \mathrm{pb}$.

Devido a grande dispersão da massa molecular dos fragmentos a reação foi mantida por mais 2 horas a $15^{\circ} \mathrm{C}$ (Figura 36).

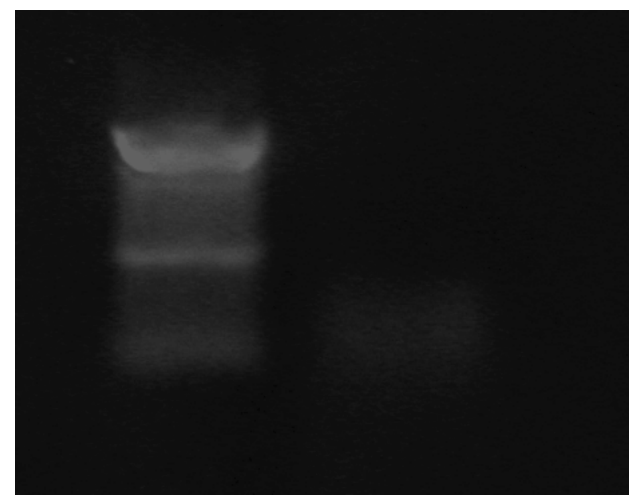

Figura 36 Eletroforese em gel de agarose a $0,8 \%$ do produto da reação de Nick translation após 6 horas de incubação a $15^{\circ} \mathrm{C}$. À esquerda, marcador de massa molecular de $1 \mathrm{~kb}$ (invitrogen). À direita, os fragmentos do vetor entre a faixa de $100-500 \mathrm{pb}$. 


\section{ANEXO 1}

MEIOS PARA MATURAÇÀO IN VITRO - MIV

Meio de lavagem MIV (Pré-MIV)

\begin{tabular}{cccc}
\hline Reagente & Fabricante & Catálogo & Volume \\
\hline M-199 com HEPES & Gibco & $12380-028$ & $9 \mathrm{ml}$ \\
Soro Fetal Bovino 10\% & Gibco & $16140-014$ & $1 \mathrm{ml}$ \\
Pyruvato 0,2mM & Sigma & P-4562 & $20 \mu \mathrm{l}$ \\
Gentamicina $50 \mu \mathrm{g} / \mathrm{ml}$ & Sigma & G-1264 & $50 \mu \mathrm{l}$ \\
\hline
\end{tabular}

Filtrar em 0,22 $\mu \mathrm{m}$

Meio de maturação in vitro

\begin{tabular}{|c|c|c|c|}
\hline Reagente & Fabricante & Catálogo & Volume \\
\hline M-199 com BICARBONATO & Gibco & $11150-026$ & $9 \mathrm{ml}$ \\
\hline Soro Fetal Bovino 10\% & Gibco & $16140-014$ & $1 \mathrm{ml}$ \\
\hline Piruvato $0,2 \mathrm{mM}$ & Sigma & P-4562 & $20 \mu l$ \\
\hline Gentamicina $50 \mu \mathrm{g} / \mathrm{ml}$ & Sigma & G-1264 & $50 \mu \mathrm{l}$ \\
\hline $\mathrm{FSH} 0,5 \mu \mathrm{g} / \mathrm{ml}$ & Bioniche & Folltropin-V & $10 \mu \mathrm{l}$ \\
\hline hCG 7Ul/ml & Intervet & Chorulon & $100 \mu l$ \\
\hline \multicolumn{4}{|l|}{ Filtrar em 0,22 $\mu \mathrm{m}$} \\
\hline Estradiol $1 \mu \mathrm{g} / \mathrm{ml}$ & Sigma & E-4389 & $10 \mu l$ \\
\hline
\end{tabular}


SOLUÇÕES ESTOQUES

Soluções estoque para FIV (Parrish et al., 1988)

\begin{tabular}{|c|c|c|c|c|}
\hline Reagente & Fabricante & Catálogo & $\begin{array}{c}\text { TALP } \\
\text { STOCK }(50 \mathrm{ml})\end{array}$ & $\begin{array}{c}\text { TALP } \\
\text { SÊMEN (50 ml) }\end{array}$ \\
\hline $\mathrm{NaCl}$ & Sigma & S-5886 & $0,3330 \mathrm{~g}$ & $0,2910 \mathrm{~g}$ \\
\hline $\mathrm{KCl}$ & Sigma & P-5405 & $0,0120 \mathrm{~g}$ & $0,0115 \mathrm{~g}$ \\
\hline $\mathrm{MgCl}_{2}$ & Sigma & M-2393 & $0,0050 \mathrm{~g}$ & $0,0040 \mathrm{~g}$ \\
\hline $\mathrm{NaH}_{2} \mathrm{PO}_{4}$ & Sigma & S-0876 & $0,00205 g$ & $0,00175 \mathrm{~g}$ \\
\hline $\mathrm{NaHCO}_{3}$ & Sigma & S-8875 & $0,1050 \mathrm{~g}$ & $0,1050 \mathrm{~g}$ \\
\hline $\mathrm{CaCl}_{2} \mathrm{H}_{2} \mathrm{O}$ & Sigma & C-5670 & $0,0150 \mathrm{~g}$ & $0,015 \mathrm{~g}$ \\
\hline Ác.Lactico syr. & Sigma & L-7900 & $71,5 \mu \mathrm{l}$ & $155 \mu l$ \\
\hline Hepes & Sigma & H-0891 & $* * * * * * * * * *$ & $0,1190 \mathrm{~g}$ \\
\hline $\mathrm{pH}=7,4$ & & & $O S M=295-300$ & \\
\hline
\end{tabular}

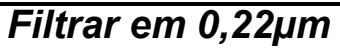

Solução de Gentamicina

\begin{tabular}{cccc}
\hline Reagentes & Fabricante & Catálogo & $100 \mathrm{ml}$ \\
\hline Sulfato de Gentamicina & Sigma & G-1264 & $50 \mathrm{mg}$ \\
Solução fisiológica & & & $100 \mathrm{ml}$ \\
\hline
\end{tabular}

Aliquotar e manter a $-20^{\circ} \mathrm{C}$. 
Solução de Piruvato

\begin{tabular}{cccc}
\hline Reagentes & Fabricante & Catálogo & $10 \mathrm{ml}$ \\
\hline Ácido Pirúvico & Sigma & P-3662 & $22 \mathrm{mg}$ \\
Água Destilada & & & $10 \mathrm{ml}$
\end{tabular}

Aliquotar e manter a $-20^{\circ} \mathrm{C}$.

Solução pH 4.0

\begin{tabular}{cccc}
\hline Reagente & Fabricante & Catálogo & $\mathbf{5 0 m l}$ \\
\hline Na Lactato & Sigma & L-7900 & $165 \mathrm{mg}$ \\
Na metabisulfito & Sigma & S-1516 & $0,050 \mathrm{~g}$ \\
Água Milli-Q (q.S.p) & & & $50 \mathrm{ml}$ \\
$\mathbf{p H}=\mathbf{4 , 0}$ & & & \\
\hline
\end{tabular}

Componentes da solução PHE

\begin{tabular}{cccc}
\hline Reagente & Fabricante & Catálogo & \\
\hline Penicilamina $2 \mu \mathrm{M}$ & Sigma & $P-40-3$ & $3 \mathrm{mg} / 10 \mathrm{ml}$ salina $0,9 \%$ \\
Hipotaurina $1 \mu \mathrm{M}$ & Sigma & $\mathrm{H}-1384$ & $1,09 \mathrm{mg} / 10 \mathrm{ml}$ salina $0,9 \%$ \\
Epinefrina $0,25 \mu \mathrm{M}$ & Sigma & $21,930-4$ & $1,83 \mathrm{mg} / 40 \mathrm{ml}$ sol. $\mathrm{pH} 4,0$ \\
\hline
\end{tabular}

Solução PHE

\begin{tabular}{cccc}
\hline Reagente & Fabricante & Catálogo & Volume \\
\hline Penicilamina & Sigma & $P-40-3$ & $2,5 \mathrm{ml}$ \\
Hipotaurina & Sigma & $H-1384$ & $2,5 \mathrm{ml}$ \\
Epinefrina & Sigma & $21,930-4$ & $2 \mathrm{ml}$ \\
Solução salina 0,9\% & & & $4 \mathrm{ml}$ \\
\hline
\end{tabular}




\section{ANEXO 2}

MEIOS PARA FIV

Meio de lavagem FIV (Pré-FIV)

\begin{tabular}{cccc}
\hline Reagente & Fabricante & Catálogo & Volume \\
\hline M-199 com HEPES & Gibco & $12380-028$ & $10 \mathrm{ml}$ \\
BSA $-\mathrm{V}$ & Sigma & A-9647 & $0,030 \mathrm{~g}$ \\
Piruvato $0,2 \mathrm{mM}$ & Sigma & P-4562 & $20 \mu \mathrm{l}$ \\
Gentamicina $50 \mu \mathrm{g} / \mathrm{ml}$ & Sigma & G-1264 & $50 \mu \mathrm{l}$ \\
\hline
\end{tabular}

Filtrar em 0,22 $\mu \mathrm{m}$

Meio FIV

\begin{tabular}{cccc}
\hline Reagente & Fabricante & Catálogo & 10ml \\
\hline TL - Stock & & & $10 \mathrm{ml}$ \\
BSA - Livre de Ácidos Graxos & Sigma & A-7511 & $0,060 \mathrm{~g}$ \\
Piruvato 0,2mM & Sigma & P-4562 & $20 \mu \mathrm{l}$ \\
Gentamicina $50 \mu \mathrm{g} / \mathrm{ml}$ & Sigma & G-1264 & $50 \mu \mathrm{l}$ \\
\hline
\end{tabular}

Filtrar em 0,22 $\mu \mathrm{m}$

Meio FIV gotas

\begin{tabular}{cccc}
\hline Reagente & Fabricante & Catálogo & 4ml \\
\hline Meio - FIV & & & $3.640 \mathrm{ml}$ \\
Heparina 140usp/mg & Sigma & H-9399 & $40 \mu \mathrm{l}$ \\
PHE & & & $160 \mu \mathrm{l}$
\end{tabular}

Filtrar em 0,22 $\mu \mathrm{m}$ 
ANEXO 3

MEIOS PARA ESPERMATOZÓIDES

Percoll $90 \%$

\begin{tabular}{|c|c|c|c|}
\hline Reagente & Fabricante & Catálogo & Quantidade \\
\hline $\begin{array}{c}\text { Percoll } \\
\text { Solução 10x }\end{array}$ & Sigma & & $\begin{array}{l}1,8 \mathrm{ml} \\
200 \mu \mathrm{L}\end{array}$ \\
\hline $\mathrm{CaCl}_{2}$ & Sigma & & $4 \mu \mathrm{L}$ \\
\hline $\mathrm{MgCl}_{2}$ & Sigma & & $7,8 \mu \mathrm{L}$ \\
\hline Ácido Láctico & Sigma & & $7,4 \mu \mathrm{L}$ \\
\hline $\begin{array}{l}\mathrm{NaHCO}_{3} \\
\text { Volume }\end{array}$ & Sigma & & $\begin{array}{c}0,0042 \mathrm{~g} \\
2 \mathrm{ml}\end{array}$ \\
\hline
\end{tabular}

Percoll 45\% - Diluir $300 \mu \mathrm{L}$ de Percoll $90 \%$ em $300 \mu \mathrm{L}$ de TALP Sêmen

TALP Sêmen

\begin{tabular}{|c|c|c|c|}
\hline Reagente & Fabricante & Catálogo & Quantidade \\
\hline $\mathrm{NaCl}$ & Sigma & & $0,2910 \mathrm{~g}$ \\
\hline $\mathrm{KCl}$ & Sigma & & $0,0115 \mathrm{~g}$ \\
\hline $\mathrm{MgCl}_{2}{ }^{*}$ & Sigma & & $0,0040 \mathrm{~g}$ \\
\hline $\mathrm{NaH}_{2} \mathrm{PO}_{4}$ & Sigma & & $0,00175 \mathrm{~g}$ \\
\hline $\mathrm{NaHCO}_{3}$ & Sigma & & $0,1050 \mathrm{~g}$ \\
\hline $\mathrm{CaCl}_{2} \mathrm{H}_{2} \mathrm{O}^{*}$ & Sigma & & $0,015 \mathrm{~g}$ \\
\hline Ácido Lático syr. & Sigma & & $155 \mu \mathrm{L}$ \\
\hline Hepes & Sigma & & $0,1190 \mathrm{~g}$ \\
\hline $\begin{array}{l}\text { BSA FAF } \\
\text { Volume }\end{array}$ & Sigma & & $\begin{array}{l}0,3 \mathrm{~g} \\
50 \mathrm{ml}\end{array}$ \\
\hline
\end{tabular}

${ }^{*}$ Pesar separadamente estes reagentes 


\section{ANEXO 4 \\ SOLUÇÕES PARA TESTE SCSA}

\begin{tabular}{|c|c|c|c|}
\hline Reagente & Fabricante & Catálogo & $500 \mathrm{ml}$ \\
\hline Tris-HCl 0,01M & Fluka & 93363 & \\
\hline $\mathrm{NaCl} 0,15 \mathrm{M}$ & Sigma & S-5886 & \\
\hline EDTA $1 \mathrm{mM}$ & Sigma & E-5134 & \\
\hline Água destilada & & & $500 \mathrm{ml}$ \\
\hline
\end{tabular}

\section{Solução pH 7.4}

Solução detergente ácida

\begin{tabular}{|c|c|c|c|}
\hline Reagente & Fabricante & Catálogo & $500 \mathrm{ml}$ \\
\hline $\mathrm{HCl} 0,08 \mathrm{M}$ & Merck & K24537117 & \\
\hline $\mathrm{NaCl} 0,15 \mathrm{M}$ & Sigma & S-5886 & \\
\hline Triton $x-1000,1 \%$ & Sigma & $X-100$ & \\
\hline Água destilada & & & $500 \mathrm{ml}$ \\
\hline
\end{tabular}

Solução pH 1.2

Solução de Laranja de Acridina (L.A) - estoque

\begin{tabular}{cccc}
\hline Reagente & Fabricante & Catálogo & $\mathbf{1 0 m l}$ \\
\hline Laranja de Acridina & Sigma & A-6014 & $60 \mu \mathrm{g}$ \\
Água destilada & & & $10 \mathrm{ml}$ \\
\hline
\end{tabular}


Solução de Laranja de Acridina - Uso

\begin{tabular}{cccc}
\hline Reagente & Fabricante & Catálogo & $\mathbf{1 2 0} \mathbf{m l}$ \\
\hline Ácido cítrico & Sigma & C-1909 & $2,52 \mathrm{~g}$ \\
$\mathrm{Na}_{2} \mathrm{HPO}_{4}$ & Sigma & S-5136 & $3,408 \mathrm{~g}$ \\
EDTA & Sigma & E-5134 & $0,04466 \mathrm{~g}$ \\
$\mathrm{NaCl}$ & Sigma & S-5886 & $1,05192 \mathrm{~g}$ \\
L.A estoque & & & $720 \mu \mathrm{l}$ \\
Água destilada q.s.p. & & & $120 \mathrm{ml}$ \\
\hline
\end{tabular}

Solução pH 6.0 